\title{
The late Miocene caimanine fauna (Crocodylia: Alligatoroidea) of the Urumaco Formation, Venezuela
}

\author{
Torsten M. Scheyer and Massimo Delfino
}

\begin{abstract}
The late Miocene Urumaco Formation at Urumaco, Falcón state, Venezuela, is remarkably rich in extinct crocodylians, presenting a diversity hotspot in the Neotropics for the group. Herein, we revise the Caimaninae fauna by including novel fossil material as well as the previously described specimens assignable to this clade. In many instances the taxonomic status of species could be confirmed, which is the case in Caiman brevirostris, Globidentosuchus brevirostris, and Purussaurus mirandai, and novel osteological data is presented to corroborate previous anatomical descriptions. In other cases, specimens needed to be reassigned to different taxa; with material previously identified as Caiman lutescens now considered as belonging to either Caiman latirostris or Caiman wannlangstoni, and material of Melanosuchus fisheri reassigned to Caimaninae aff. Melanosuchus fisheri. Furthermore, Mourasuchus nativus is considered to be a junior synonym of Mourasuchus arendsi herein. This suggests that there are only three species of the duck-billed caimanine Mourasuchus present in the Miocene of South America, having colonised the continent from the northwest (Colombia and Peru) during the middle Miocene and moving to the east and southeast (Venezuela, Brazil and Argentina) in the late Miocene. Other specimens, which were previously identified as belonging to the genus Caiman, lack diagnostic features of the modern genus and are instead considered as Caimaninae indet. Besides improving the knowledge of the late Miocene crocodylians of South America, our results confirm the high taxonomic diversity of the fauna and the outstanding level of sympatry previously reported for the Urumaco Formation.
\end{abstract}

Torsten M. Scheyer. Paläontologisches Institut und Museum, Universität Zürich, Karl Schmid-Strasse 4, $\mathrm{CH}-8006$ Zürich, Switzerland tscheyer@pim.uzh.ch Massimo Delfino. Dipartimento di Scienze della Terra, Università di Torino, Via Valperga Caluso 35, I10125 Torino, Italy. massimo.massimo.delfino@unito.it and Institut Català de Paleontologia Miquel Crusafont, Universitat Autònoma de Barcelona. Edifici ICTA-ICP, Carrer de les Columnes s/n, Campus de la UAB, E-08193 Cerdanyola del Vallès, Barcelona, Spain

Keywords: caimanines; Crocodylia; faunal composition; Globidentosuchus; Mourasuchus; Purussaurus

Submission: 9 March 2016 Acceptance: 29 August 2016

Scheyer, Torsten M. and Delfino, Massimo. 2016. The late Miocene caimanine fauna (Crocodylia: Alligatoroidea) of the Urumaco Formation, Venezuela. Palaeontologia Electronica 19.3.48A: 1-57

palaeo-electronica.org/content/2016/1625-caimanines-from-urumaco-formation

Copyright: () November 2016 Society of Vertebrate Paleontology. This is an open access article distributed under the terms of the Creative Commons Attribution License, which permits unrestricted use, distribution, and reproduction in any medium, provided the original author and source are credited.

creativecommons.org/licenses/by/4.0/ 


\section{INTRODUCTION}

The crocodylian fauna from the late Miocene badlands of Urumaco, Falcón State, Venezuela is highly diverse, with up to seven sympatric species having been described (Scheyer et al., 2013). It is only due to recent detailed stratigraphic work carried out in the Urumaco region (Quiroz and Jaramillo, 2010) that a more refined image of the faunal crocodylian composition is known, and the taxonomic evaluation of the rich fossil material can be studied within a well-established sedimentarystratigraphic framework (e.g., Aguilera, 2004; Aguilera et al., 2006; Riff and Aguilera, 2008; Riff et al., 2010; Scheyer et al., 2013). Given the scarcity of vertebrate fossils found in the tropical regions of South America, these fossils, together with other faunal elements, have a major impact on our understanding of crocodylian evolution in the Neotropics. Despite the fact that over the past decades an exceptionally large number of cranial remains were collected in the field (as these are the most informative for taxonomy and systematics), many specimens remain undescribed and/or unfigured.

Two previous works presented overviews of many of the important crocodylian specimens from Urumaco (Aguilera, 2004; Sánchez-Villagra and Aguilera, 2006), and crocodylian faunal lists were published (Riff et al., 2010; Scheyer et al., 2013). Here we expand on these works and present novel osteological descriptions and anatomical details of the crocodylian fossils that could be identified as belonging to Caimaninae (Figure 1 ) in the palaeontological collections of Urumaco, Coro, and Caracas; the largest collections housing fossils of the Urumaco Formation. In many cases for the first time, photographs and interpretative drawings of specimens are given, which have an impact on the taxonomic assignment of the fossils. The current contribution is also intended to allow for a closer comparison of specimens with other Neogene faunas from South America in order to obtain a clearer understanding of systematics and biogeographic patterns. These include: the Ituzaingó Formation, Paraná area, northeastern Argentina (Bona et al., $2013 b$, c), the Culebra Formation, Panama canal zone of Panama (Hastings et al., 2013), the Pebas Formation, Pebas mega-wetland system of Peru (Salas-Gismondi et al., 2015), the Jimol, Castilletes, and Ware formations, Guajira Peninsula of Colombia (Moreno-Bernal et al., 2016) and the Solimões Formation, Acre State, Brazil and Honda Group, Colombia (Riff et al., 2010 and references therein). The treatment of the gharials and remain- ing crocodylian faunal elements of the Urumaco Formation is currently in preparation elsewhere.

\section{MATERIALS AND METHODS}

Material from the largest collections (Caracas, Coro, and Urumaco) that house fossil specimens from the Urumaco Formation were studied. All materials are stored and available for study in the respective repositories in Venezuela. A list of studied specimens is available in Appendix 1 (separate supplemental file). Note that specimen numbers ending on "-72V" in the Museo de Ciencias Naturales de Caracas collections refer to the original field notes by the 'Harvard expedition' led by Brian Patterson and colleagues from the Museum of Comparative Zoology of Harvard University in June/July 1972, during which the material was collected (Patterson et al., 1972).

\section{Institutional Abbreviations}

AMU-CURS, Colección de Paleontología de Vertebrados de la Alcaldía de Urumaco, Estado Falcón, Venezuela; DGM, Divisão de Geologia e Mineralogia do Departamento Nacional da Producao Mineral, Rio de Janeiro, Brazil; MACN PV, Museo Argentino de Ciencias Naturales "Bernardino Rivadavia", Paleontología Vertebrados, Buenos Aires, Argentina; MCNC, Museo de Ciencias Naturales de Caracas, Venezuela; MCN-USB, Museo de Ciencias Naturales, Universidad Simon Bolivar Caracas, Venezuela; MCZ, Museum of Comparative Zoology, Harvard University, Cambridge, MA, USA; MLP, Museo de La Plata, Buenos Aires, Argentina; MUSM, Natural History Museum of San Marcos University, Lima, Peru; UCMP, University of California at Berkeley, Museum of Paleontology; UFAC, Universidade Federal do Estado de Acre, Rio Branco, Brazil; UNEFM-CIAAP, Universidad Nacional Experimental Francisco de Miranda / Centro de Investigaciones Antropológicas, Arqueológicas y Paleontológicas, Coro, Venezuela; ZSM, Zoologische Staatssammlung München, Germany.

\section{SYSTEMATIC PALAEONTOLOGY}

\section{Genus CAIMAN Daudin, 1802 \\ Caiman brevirostris Souza Filho, 1987}

The species Caiman brevirostris was described from the Miocene Solimões Formation of Acre, Brazil based on fragmentary cranial remains carrying crushing teeth (Souza Filho, 1987). Prior to the description the Globidentosuchus brachyrostris from Urumaco, a small form with a strong 

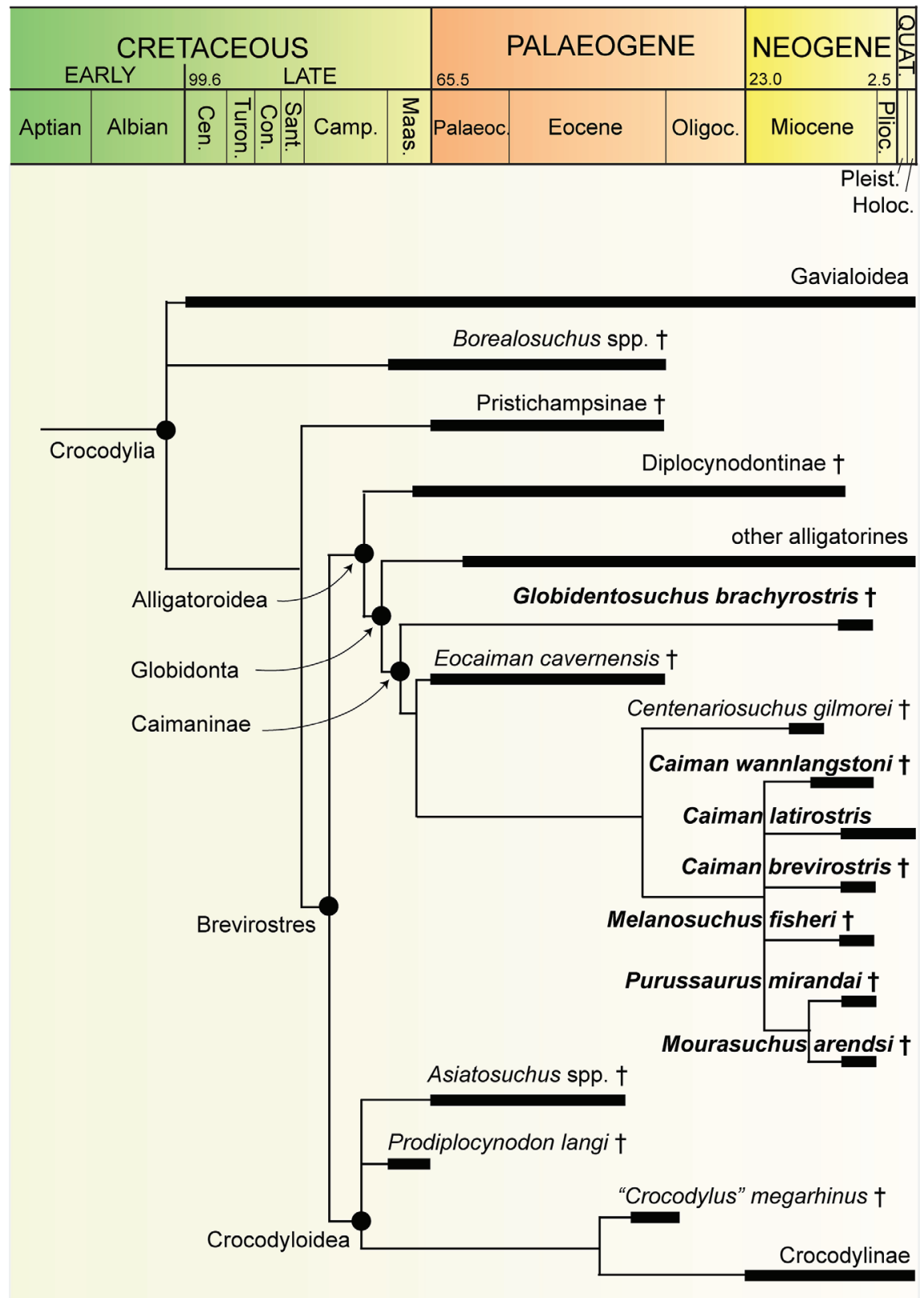

FIGURE 1. Simplified phylogenetic framework based on Scheyer et al. (2013) and Salas-Gismondi et al. (2015). The caimanine taxa present in the Urumaco Formation are marked in bold face.

crushing dentition (Scheyer et al., 2013), most small caimanine remains were referred to $C$. brevirostris. It was only with the description of new material of $C$. brevirostris from the late Miocene Solimões Formation of Amazonas state, Brazil, that an emended diagnosis of the species was given, and detailed images and drawings of the holotype material were provided (Fortier et al., 2014). Detailed comparison of small caimanine remains from the Urumaco Formation leads us to propose that only a single specimen, MCNC-1829, is attributable to $C$. brevirostris.

MCNC-1829 (Figure 2) shows a well-developed durophagous dentition in the broad and short skull and robust lower jaw, which are congruent with that of the holotype of Caiman brevirostris (Fortier et al., 2014). A splenial symphysis is lacking in C. brevirostris (Fortier et al., 2014), but with the upper and lower jaw being in articulation, it cannot be determined whether the splenial partici- 


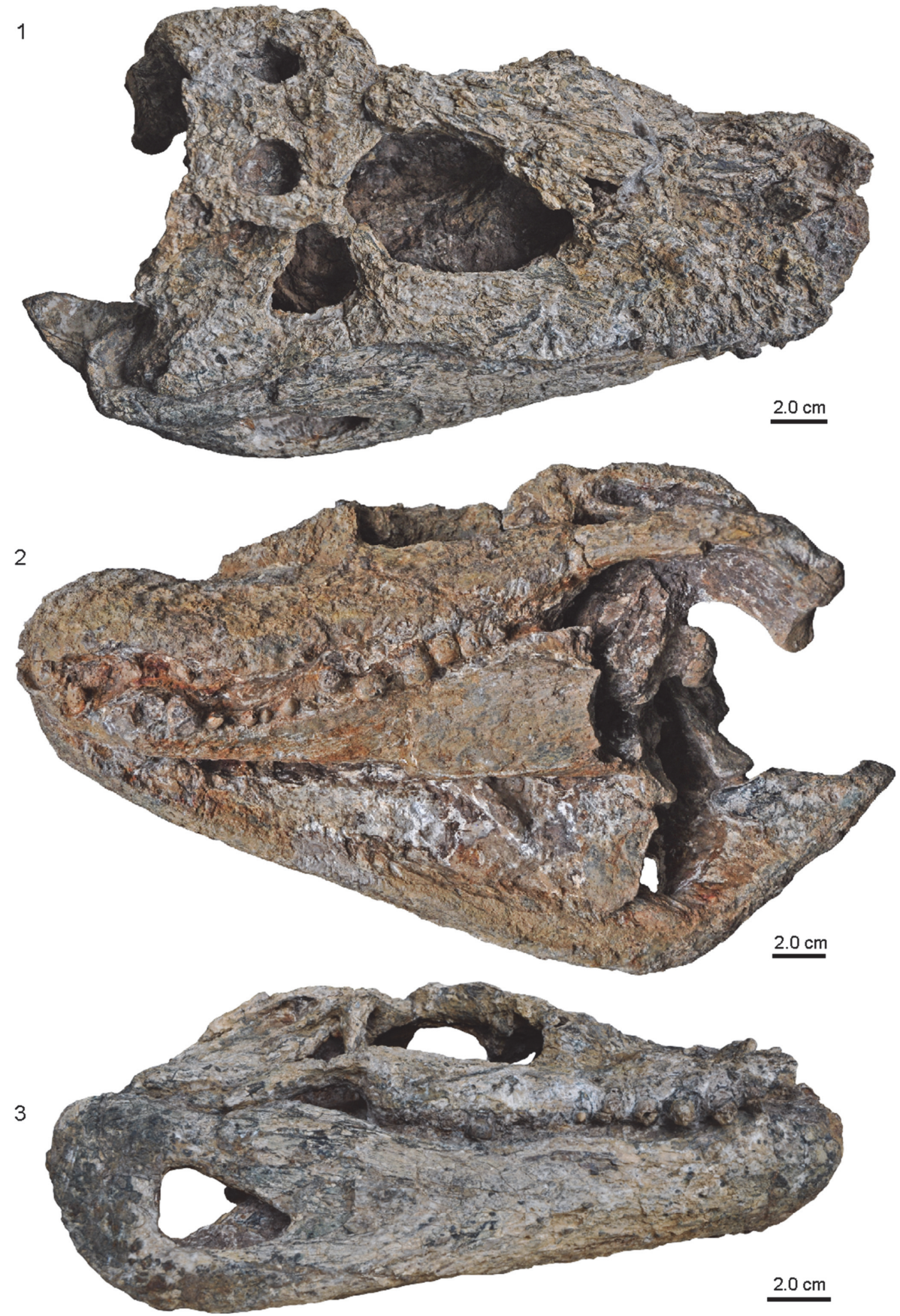

FIGURE 2. Photographs of Caiman brevirostris (MCNC-1829). 1, right dorsolateral view. 2, left ventrolateral view. 3, right lateral view. Note that the specimen is strongly crushed and folded in on itself.

pates in the symphysis or not in MCNC-1829 (Figures 2,3$)$. The frontal meets the nasals in MCNC1829 (Figure 3.1-2) as in the holotype of C. brevirostris (UFAC-196), whereas in Globidentosuchus brachyrostris (e.g., in the holotype AMU-CURS222), the prefrontals meet broadly medially, thus separating the frontal from the nasals (Figure 4; Scheyer et al., 2013). The latter condition is also present in the holotype of Melanosuchus fisheri (MCNC-243) and can also occur in some specimens of extant M. niger (Mook, 1921, figure 11), whereas the prefrontals are usually separated by a frontal-nasal contact in extant Caiman latirostris (Bona and Desojo, 2011). Furthermore the supratemporal fenestrae appear larger in a less expanded skull table (although at least partial 

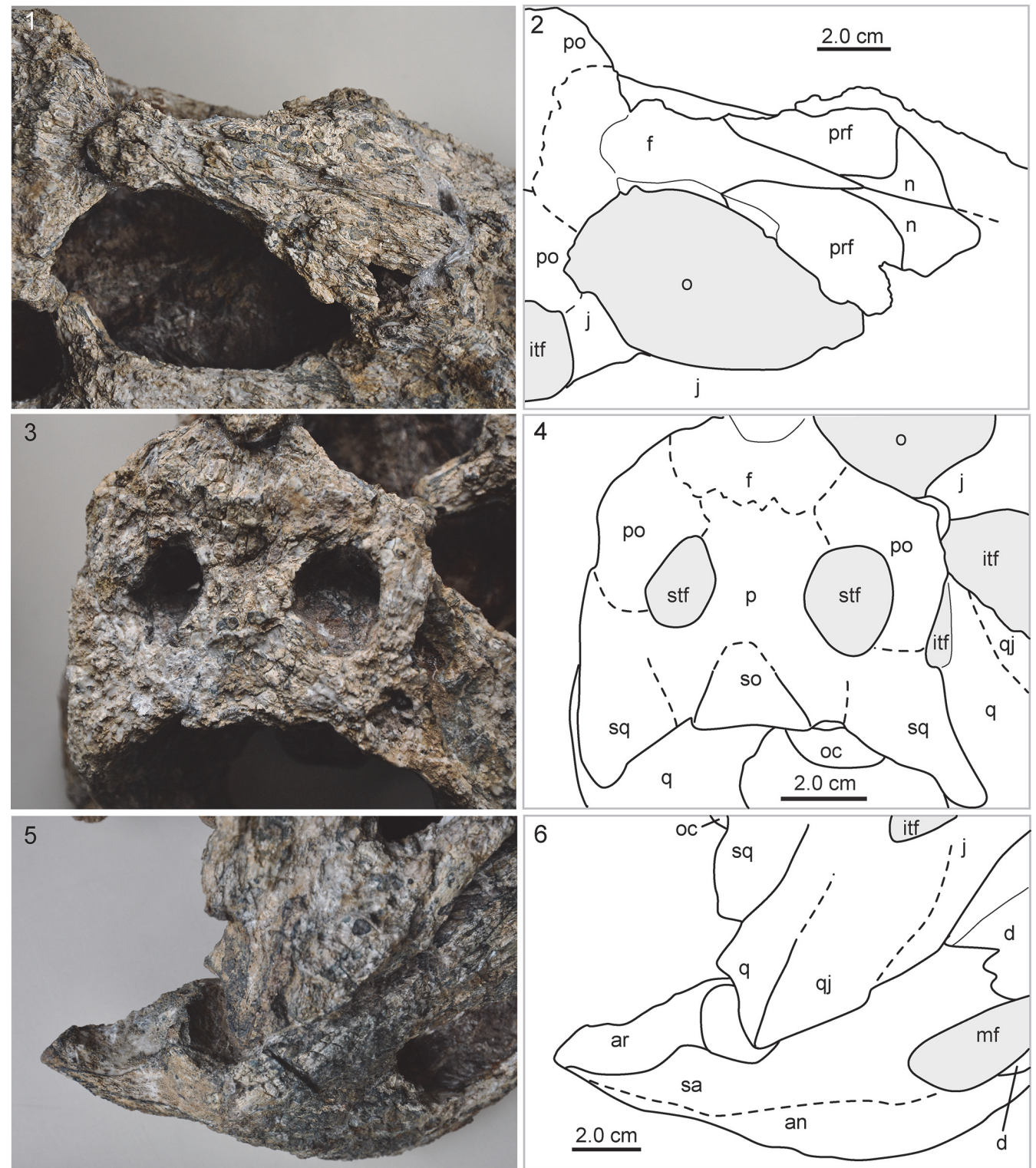

FIGURE 3. Photographs $(\mathbf{1}, \mathbf{3}, \mathbf{5})$ and interpretative drawings $(\mathbf{2}, \mathbf{4}, \mathbf{6})$ of Caiman brevirostris (MCNC-1829). 1, 2, close-up of the fronto-nasal contact in right dorsolateral view. 3, 4, close-up of the skull roof in dorsal view. 5, 6, closeup of the craniomandibular articulation in slanted right dorsolateral view. Abbreviations: an, angular, ar, articular; $d$, dentary; f, frontal; j, jugal, itf, infratemporal fenestra; mf, mandibular fenestra; $\mathrm{n}$, nasal; o, orbit; oc, occipital condyle; po, postorbital; prf, prefrontal, q, quadrate; qj, quadratojugal; sa, surangular; so, supraoccipital; sq, squamosal; stf, supratemporal fenestra.

taphonomic expansion of the supratemporal fenestrae cannot be ruled out), and the supraoccipital has a trapezoidal exposure in MCNC-1829, which appears not to exclude the parietal from reaching the posterior skull margin (Figure 3.3-4). In occipital view (Figure 5), the distortion of the skull is clearly visible. The squamosals and the supraoccipital form the posterior margin of the skull table, but sutures with the exoccipitals are not discernible. The foramen magnum has a dorsoventrally elongated appearance because of the mediolateral compression the specimen experienced, but was probably broad oval-shaped in life; its margins are formed by the basioccipital ventromedially and by the exoccipitals ventrolaterally, laterally, and dorsally. In the lower jaw, the angular-surangular suture enters the mandibular fenestra at about half the height of its posterior margin (Figure 3.5-6). The angular-surangular suture reaches the posterior tip of the short retroarticular process in MCNC- 
1

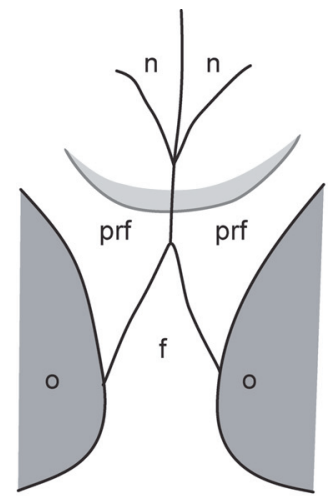

4

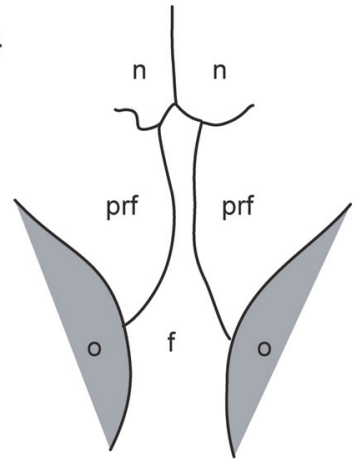

7

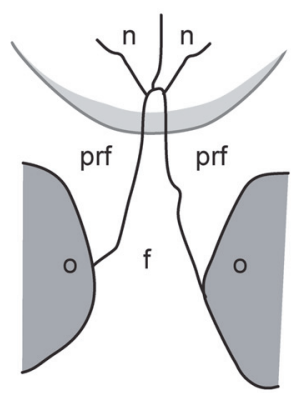

2

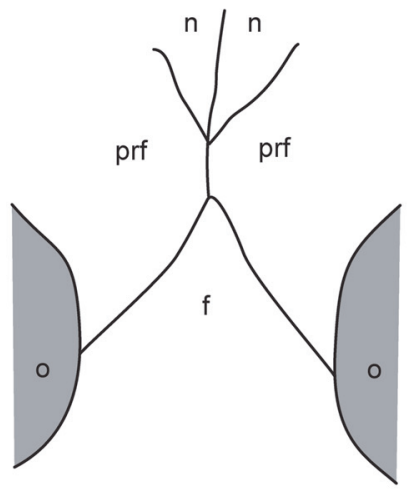

5

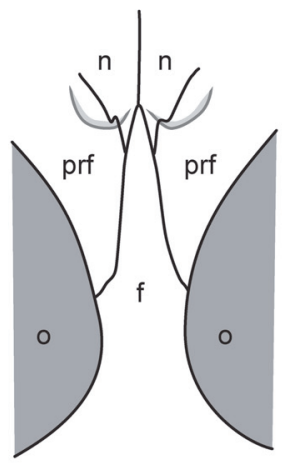

8

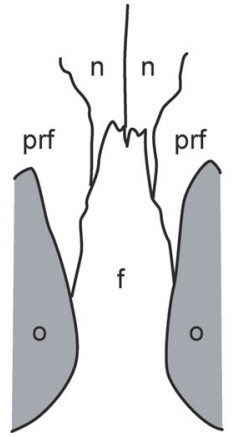

3

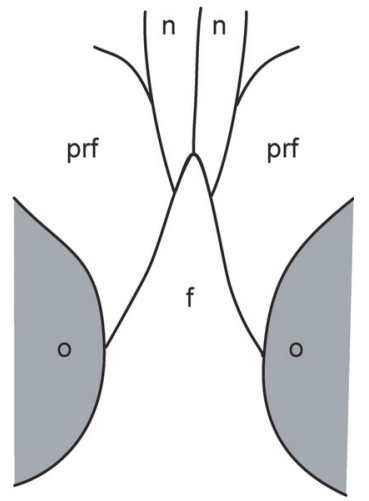

6

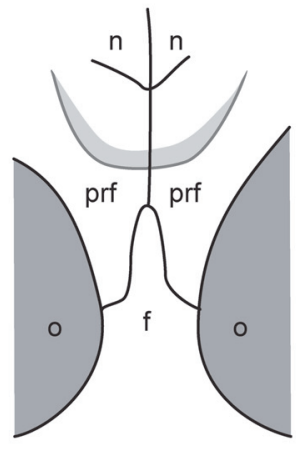

9

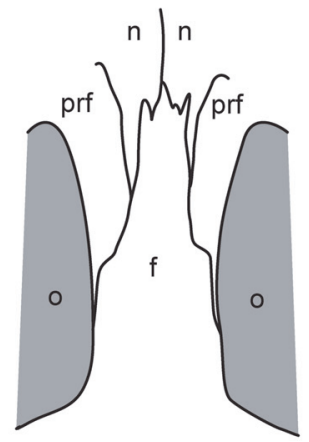

FIGURE 4. Interpretative drawings of skull bone configuration in the rostro-orbital region of three small sized caimanines from the Urumaco Formation, in comparison to three living caimanines (anterior is to the top). 1, Melanosuchus fisheri based on holotype skull MCNC-243. 2, Globidentosuchus brachyrostris based on holotype skull AMUCURS-222. 3, Caiman brevirostris based on MCNC-1829 from the late Miocene Urumaco Formation, Urumaco, Venezuela. 4, Caiman brevirostris from the Pleistocene of Acre, Brazil (UFAC-196) originally described by Souza Filho (1987, also figured in Fortier et al., 2014). Note that the anterior projection of the frontal appears much broader in the Venezuelan specimen than in the Pleistocene specimen. 5, extant Melanosuchus niger based on ZSM 76/1911 (picture courtesy: Julia Desojo; see also Foth et al., 2015). 6, extant Caiman crocodilus based on lordansky (1973, figure 7A). 7, extant Caiman latirostris based on Bona and Desojo (2011, figure 2). 8, extant Paleosuchus trigonatus and $\mathbf{9}$, extant Paleosuchus palpebrosus based on Medem (1958, figure 36). The bridge of the 'spectacles' between the orbits is indicated in 1, 5, 6, and 7. Drawings not to scale. Abbreviations: f, frontal; $n$, nasal; o, orbit; prf, prefrontal.

1829 , although the latter is somewhat incompletely preserved. Due to the overall strongly weathered condition of MCNC-1829, other sutures in the skull and lower jaw are partly or completely obscured and therefore yield little additional information.
Caiman latirostris (Daudin, 1802) and Caiman wannlangstoni (Salas-Gismondi, Flynn, Baby, Tejada-Lara, Wesselingh, and Antoine, 2015)

The species Caiman lutescens was originally described as a species of Alligator from the Miocene "capas del Paraná" in northeastern Argentina 


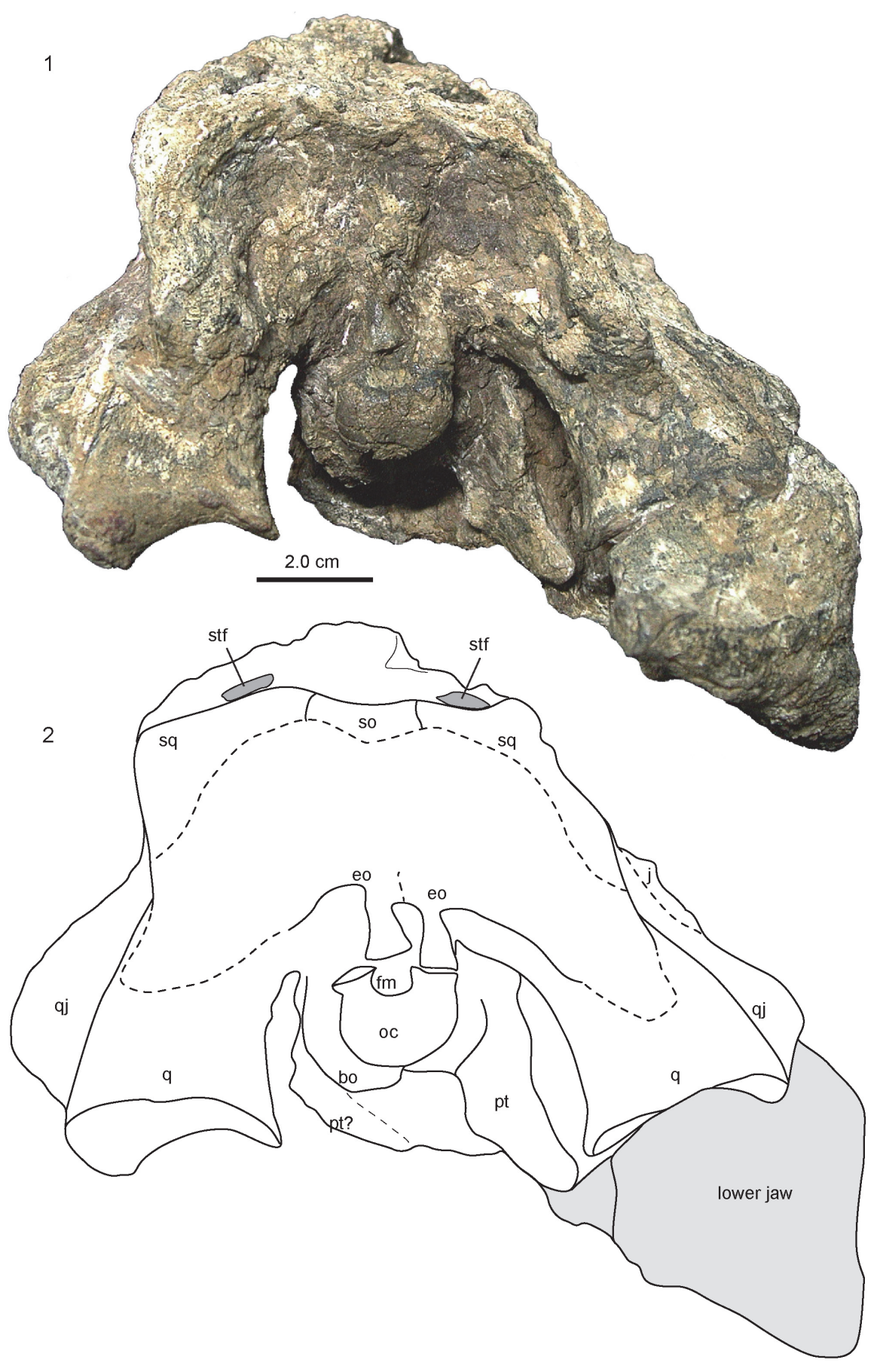

FIGURE 5. Photograph (1) and interpretative drawing (2) of Caiman brevirostris (MCNC-1829) in occipital view. Abbreviations: bo, basioccipital; eo, exoccipital; fm, foramen magnum; j, jugal; so, supraoccipital; sq, squamosal; stf, supratemporal fenestra; oc, occipital condyle; pt, pterygoid; q, quadrate; qj, quadratojugal.

(Rovereto, 1912) based on two specimens (see below) and was sometimes proposed to be a junior synonym (see Riff et al., 2010 for discussion) of the modern broad snouted caiman Caiman latirostris. Bona et al. (2013b, c) reanalysed the type material of $C$. lutescens, and identified and figured MACN
PV 13551 (a skull table) as the holotype. The second type specimen, MACN PV 5416 (partial right rostrum) was reassigned by Bona et al. (2013b, 2013c) to the extant species $C$. latirostris. In dorsal view MACN PV 5416 shows a strong lateral festooning of the skull margin, although this is a fea- 
ture which is less prominent in the extant species (Bona and Desojo, 2011). Langston (1965) also described a fragmentary skull (UCMP 39978) from La Venta fauna, Colombia, as Caiman cf. C. lutescens based on comparison with MACN PV 5416 the partial right rostrum. Some of the characteristics given by Langston (1965) for UCMP 39978, which according to (Bona et al., 2013b) lack data comparable to the holotype of $C$. lutescens, are: triangular head shape in dorsal view with blunted tip of snout; bulbous appearance of skull in lateral view in the region of the external naris; large undivided external naris that is a bit wider than long; nasals that do not enter the external naris; strong facial canthi across the rostrum as in spectacled caimans; and an upper tooth row comprising 18 alveoli, five of which are in the premaxilla. As in MACN PV 5416, the fourth, ninth, and fourteenth maxillary alveoli are the largest in the series, but UCMP 39978 does not show strong lateral festooning of the skull margin in dorsal view (Rovereto, 1912; Langston, 1965). Salas-Gismondi et al. (2015) erected a new caimanine species, Caiman wannlangstoni, from the late middle Miocene Pebas Formation of the Iquitos area in Peru, the holotype of which is a partial skull (MUSM 2377) with lateral margins that are strongly sinuous and distinctly diverging posteriorly in dorsal view. The authors indicate that specimen UCMP 39978 shows some affinities to $C$. wannlangstoni, but they treat its taxonomic status for the time being as a "La Venta Caiman" and a "distinct entity of uncertain taxonomic affinities."

AMU-CURS-49 from Urumaco was previously identified as belonging to Caiman lutescens (Aguilera, 2004). It consists of a fragmentary right premaxilla and maxilla, comprising 17 alveoli in total (premaxillary alveoli 2-5, the first alveolus is not preserved; maxillary alveoli 1-13), hosting three (partially) preserved teeth, as well as a sliver of the right nasal entering the external narial opening (Figure 6). The posterior suture of the nasal with the premaxilla and maxilla is not determinable with confidence. The specimen was figured both in Aguilera (2004) and Sánchez-Villagra and Aguilera (2006), and a short description in Spanish was given in the former work. As noted by Aguilera (2004), the lateral margin of the specimen is festooned in dorsal view, with a series of convexities that coincide with the presence of the largest alveoli in the series (the fourth premaxillary alveolus and the fourth and tenth of the preserved maxillary alveoli), one of the characters of the Argentinian (MACN PV 5416) and the Colombian material
(UCMP 39978). Salas-Gismondi et al. (2015, page 6) refer AMU-CURS-49 to the recently erected species $C$. wannlangstoni, based on its "strong sinuous rostral margins and robust globular posterior teeth." According to Bona and Desojo (2011) in modern $C$. latirostris the lateral margins of the rostrum are more triangular and not wavy/festooned in dorsal view, whereas in ventral view, slight convexities also coincide with the largest alveoli in the premaxilla and maxilla (as Langston, 1965 described in UCMP 39978). Aguilera (2004) described the ninth and tenth maxillary alveolus in AMU-CURS49 as being confluent (= the thirteenth and fourteenth in Aguilera, 2004). Similarly, the eighth and ninth alveoli could be confluent as well, with the teeth standing very close to each other and the intermediate alveolar bone wall being very thin, if present at all. Given the weathering the specimen experienced in this area, this anatomical aspect remains inconclusive, however. Two large occlusion pits are present, the first is only partially preserved at the level of the second and third premaxillary alveolus, and the second lies medially to the fifth premaxillary and the first maxillary alveolus (corresponding to a small diastema). Two faint impressions of smaller occlusion pits are situated anteromedial and posteromedial to the fourth premaxillary alveolus. The number of teeth, as well as shape of the alveoli and occlusion pits are thus very similar to those in modern C. latirostris (Bona and Desojo, 2011). The maxillary-premaxillary suture is visible laterally and dorsolaterally on the specimen (Figure 6), but gets increasingly obscured medially (both on the dorsal and ventral surface). Size and shape of the external narial aperture and the orbit remains ambiguous in AMUCURS-49 because it is too fragmentarily preserved in these areas.

Another rostral fragment, MCNC-URU-14572V (=MCNC-URU-2002-145), from the Urumaco Formation was previously identified as belonging to Caiman lutescens as well (Aguilera, 2004). It comprises of the left premaxilla, the anterior portion of the left maxilla, and the anterior portion of the left nasal bone (Figure 7). The sutures of the three bones are clearly visible dorsally and ventrally. The premaxilla forms the anterior, lateral, and posterolateral portions of the external naris, and the nasal enters the external naris posteriorly. The external naris is undivided, slightly constricted posteriorly, with slightly concave borders in the posterior half and more strongly concave (crescent-shaped) borders in the anterior half. Ventrally, the tooth row of the premaxilla and the preserved anterior maxillary 

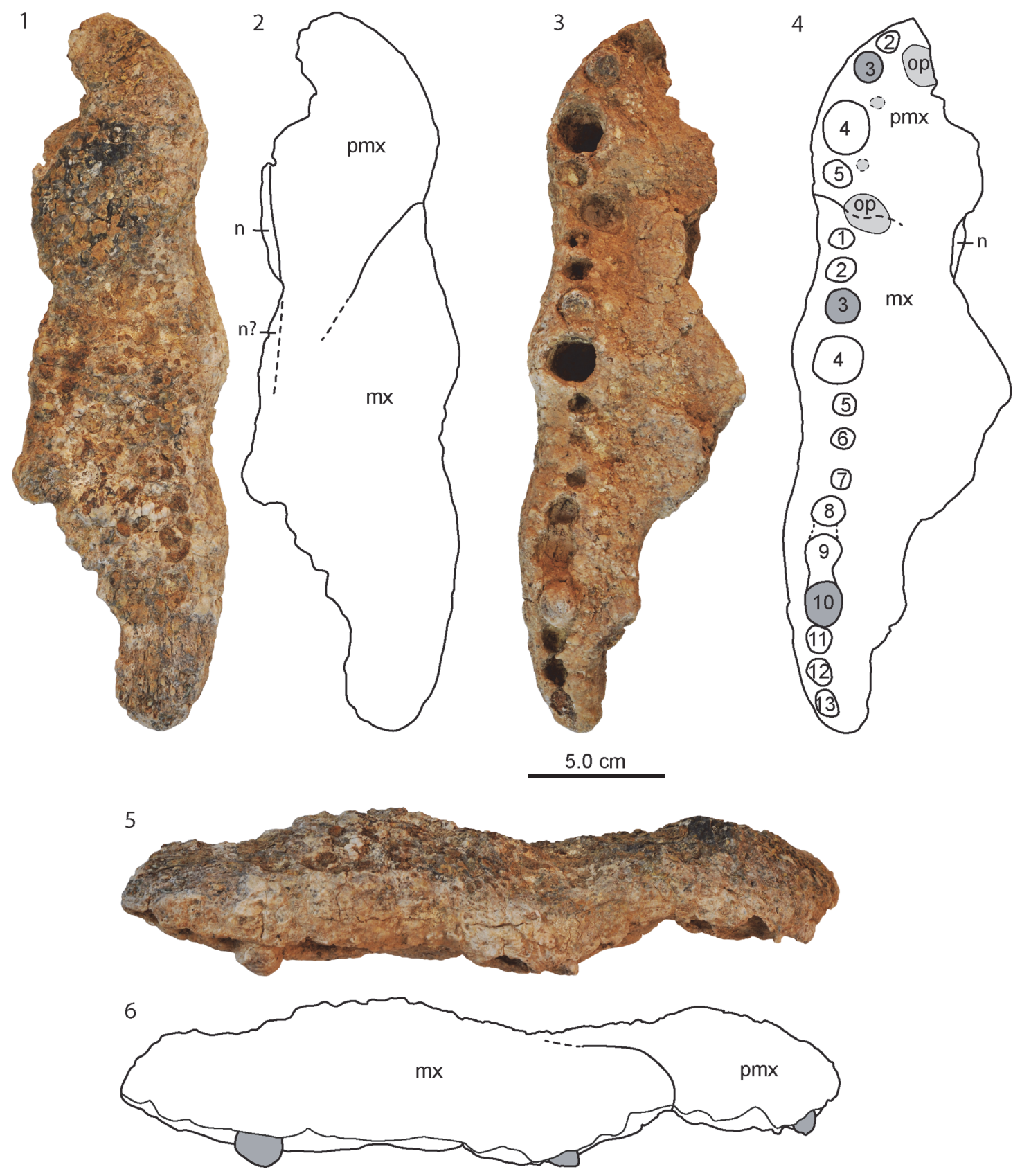

FIGURE 6. Photographs $(\mathbf{1}, \mathbf{3}, \mathbf{5})$ and interpretative drawings $(\mathbf{2}, \mathbf{4}, \mathbf{6})$ of Caiman wannlangstoni (AMU-CURS-49). 1, 2, dorsal view. 3, 4, ventral view. 5, 6, right lateral view. Occlusion pits are marked in grey. The partially preserved teeth in the third premaxillary alveolus and the third and tenth maxillary alveoli are marked in dark grey. Note that the two occlusion pits anteromedial and posteromedial to the fourth premaxillary alveolus are preserved only as very faint impressions on the bone surface. Abbreviations: mx, maxilla; $\mathrm{n}$, nasal; op, occlusion pit; pmx, premaxilla.

portion contains nine alveoli in total (four in the premaxilla and five in the maxilla), with the fourth alveolus in the premaxilla being the largest. There is a large gap between maxillary alveoli 3 and 4, with the alveolar bone showing a generally rough irregular structure here. In comparison with AMUCURS-49, its lateral margins are not highly sinu- ous, but reminiscent of the condition seen in C. latirostris. We propose that one maxillary alveolus (either the third or the fourth) has not been developed in MCNC-URU-145-72V, thus creating the larger distance between the alveoli here. Premaxillary alveolus 4 is the only one containing a tilted tooth fragment. There are four distinct depressions 


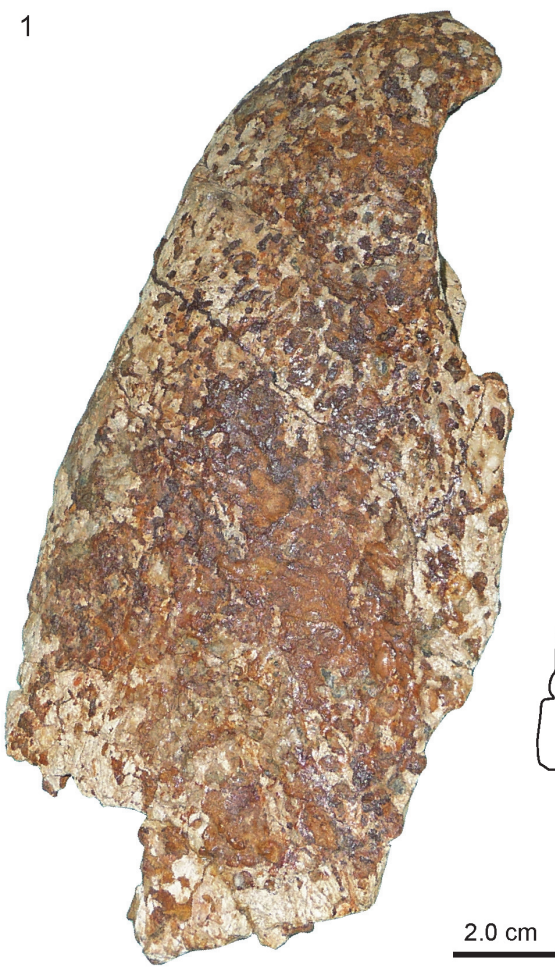

3
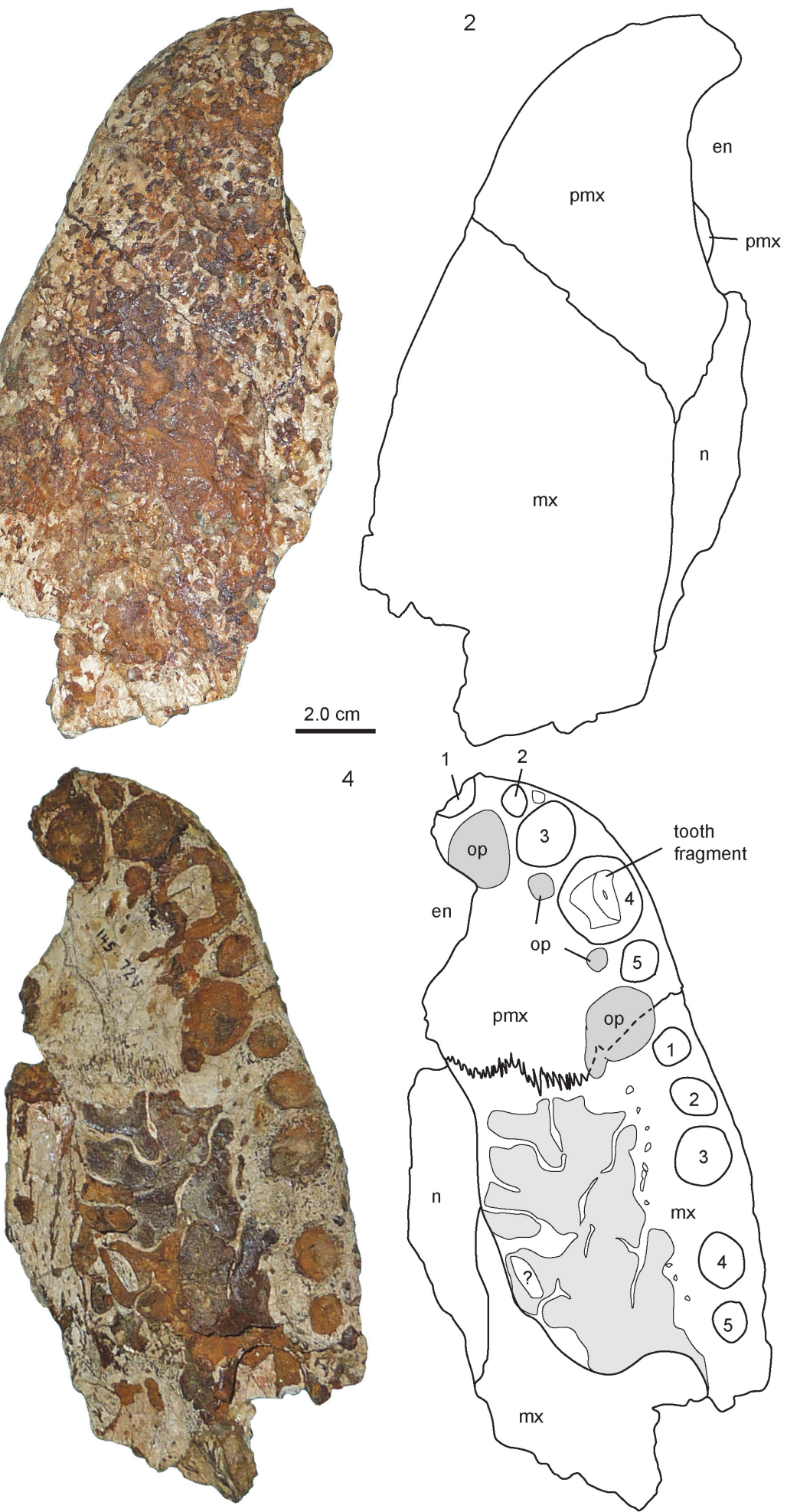

FIGURE 7. Photographs $(\mathbf{1}, \mathbf{3})$ and interpretative drawings $(\mathbf{2}, \mathbf{4})$ of Caiman latirostris (MCNC-URU-145-72V). 1, 2, dorsal view. 3, 4, ventral view. Alveoli are marked with numbers, occlusion pits in dark grey. The internal trabecular space within the maxilla is marked in light grey. Abbreviations: en, external naris; mx, maxilla; $n$, nasal; op, occlusion pit; pmx, premaxilla. 
identified as occlusion pits that accommodate the teeth of the lower jaw, one large and deep occlusion pit posterior to premaxillary alveolus 1 (which is partially broken anteriorly) and 2, followed by two small occlusion pits anteromedial and posteromedial to premaxillary alveolus 4 . The fourth occlusion pit, again wide and deep, lies on the premaxillarymaxillary suture between the fourth premaxillary and first maxillary alveolus. Posteromedial, the deep occlusion pit is confluent with a much smaller pit, which, in comparison with extant Caiman latirostris skulls, opens into a large neurovascular foramen, the premaxilla-maxilla foramen that houses part of the maxillary branch of the trigeminal nerve. Posteriorly to the depressions and medial to maxillary alveoli 1 to 3 lies a row of eight small dental foramina. There are about three more foramina present medial to maxillary alveoli 4 and 5 , but here the secondary palate portion of the maxilla is partially eroded posteromedially, so that the internal trabecular support structures of the maxilla are exposed. Medially, the ventral side of the nasal bone is visible, forming the roof of the nasopalatine duct. The posterior margin of the specimen is formed by the ventral exposure of the dorsal compacta of the maxillary bone.

Genus GLOBIDENTOSUCHUS Scheyer, Aguilera, Delfino, Fortier, Carlini, Sánchez, Carrillo-Briceño, Quiroz and Sánchez-Villagra, 2013

The genus Globidentosuchus (type and only species G. brachyrostris) was described recently by Scheyer et al. (2013) based on skull and lower jaw material from the Middle and Upper Members of the Urumaco Formation (holotype AMU-CURS222; additional specimens AMU-CURS-223, -224, $-301,-383$ and -450$)$. We here refer additional material, AMU-CURS-067 (Figures 8, 9), to this taxon.

Globidentosuchus brachyrostris Scheyer, Aguilera, Delfino, Fortier, Carlini, Sánchez, Carrillo-Briceño, Quiroz and Sánchez-Villagra, 2013

The material accessioned as AMU-CURS-067 (Figures 8,9 ) from the Playa Larga locality, Middle Member of Urumaco Fm. includes: 1) a left mandibular ramus (35.6 cm preserved length) lacking part of the anterior symphyseal tip and posteriorly part of the surangular and angular, including the retroarticular process; 2) a fragment of the right mandibular ramus which lacks most of the anterior symphyseal area and everything posterior to the anterior edge of the external mandibular fenestra; 3) a fragment of the right maxilla with 7.5 alveoli, three of which carry tooth remains; 4 ) a fragment of a right premaxilla preserving 3.5 alveoli; and 5) an indeterminate cranial bone. In addition, four vertebrae and six other bone fragments were found associated with the above-mentioned cranial and mandibular bones.

The left mandibular ramus has the 14 posterior-most alveoli preserved, with the last eight still carrying teeth or broken-off tooth stumps. Given the shape of the preserved teeth and sizes of the alveoli, eight large crushing teeth were present in the living animal, similar to the condition in the holotype (Scheyer et al., 2013). This specimen also shows the outlines of the external mandibular fenestra and the foramen intermandibularis caudalis, and a surangular-angular suture which extends more or less horizontally towards the posterior margin of the ramus (this suture is angled upwards in the holotype material of Caiman brevirostris, see Fortier et al., 2014). Both mandibular rami have the splenial participating anteriorly in the mandibular symphysis as in other specimens of Globidentosuchus brachyrostris and the sutural contacts of most of the bones in the posterior portion of the mandible are traceable (Figure 9). The right portion of the mandible also carries a pathological circular bony excrescence lateral to the first and second crushing tooth. The premaxillary and the maxillary fragments and the surangular-angular portion of the right mandibular ramus also have pitting patterns preserved on the external bone surface.

The right maxilla fragment preserves the anterior portion of the bone from alveolus 1 (only partially preserved) to alveolus 8 . The fourth alveolus has the largest diameter, followed by the adjacent alveoli anteriorly and posteriorly. Alveoli 6 to 8 are slightly labiolingually compressed, while alveoli 2 to 5 are filled with broken-off teeth remains. Dorsally the maxilla fragment is slightly domed, showing some irregularly spaced foramina. The borders of the premaxilla and the opposite maxilla are not preserved. The premaxillary fragment, on the other hand, is interpreted as including alveoli 2 to 4 , with the fourth being the largest and the remaining two being of equal size. Anteromedially to alveolus 2, the first large occlusion pit is preserved. Dorsally the fragment is similarly domed and the surface carries numerous foramina. The borders of the external naris and the incisive foramen are not preserved.

Globidentosuchus cf. G. brachyrostris Scheyer, Aguilera, Delfino, Fortier, Carlini, Sánchez, CarrilloBriceño, Quiroz and Sánchez-Villagra, 2013

AMU-CURS-083, -084 and UNEFM- VF-017 represent remains of small, broad-snouted cai- 

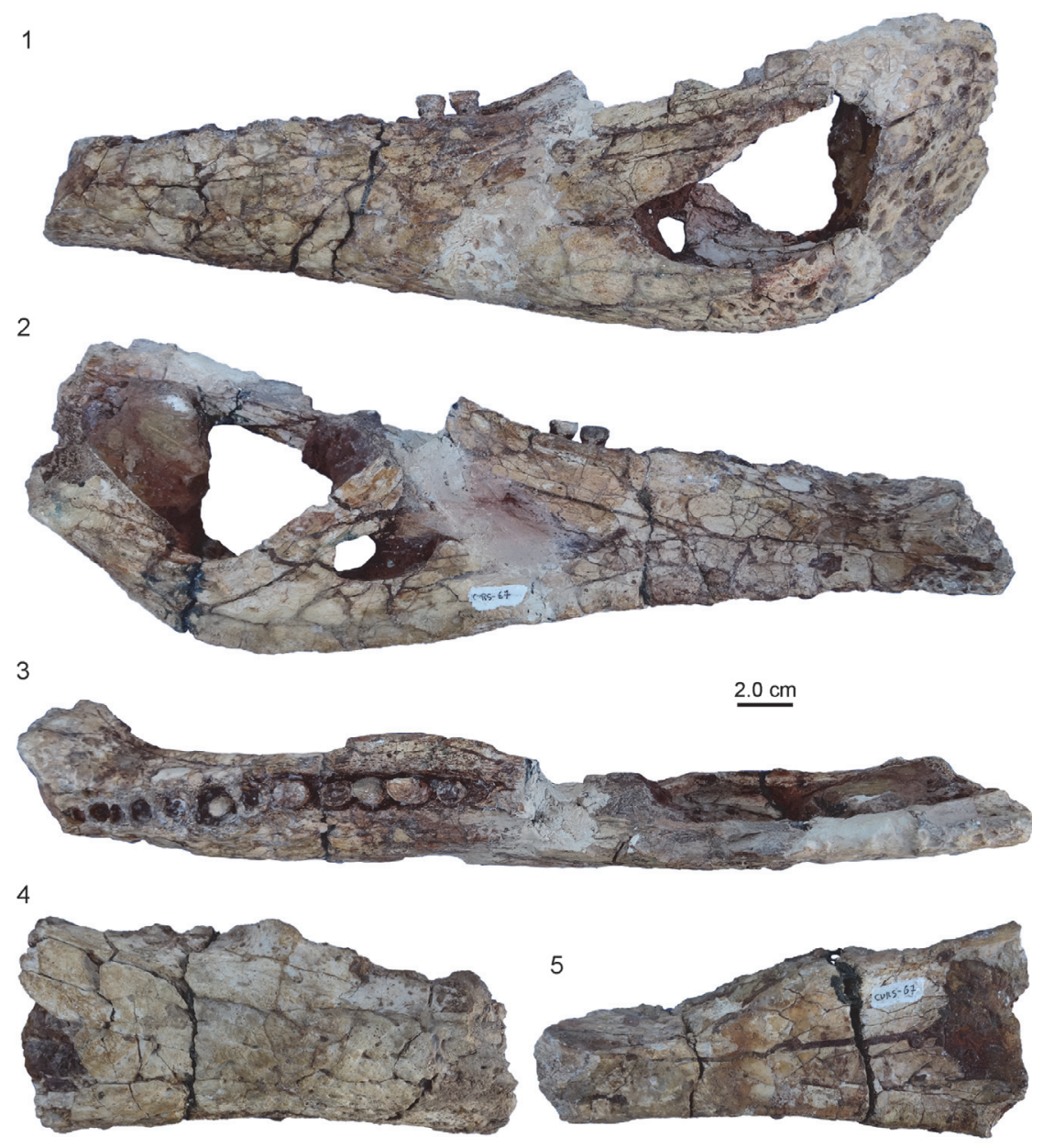

6
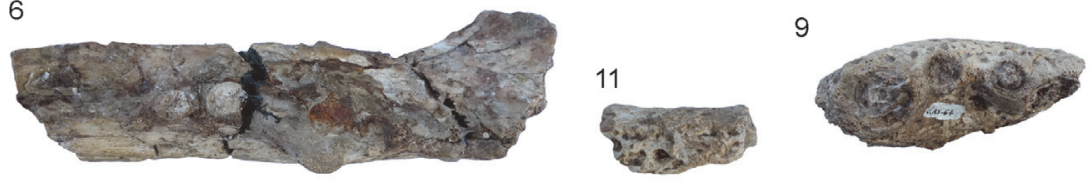

7

8
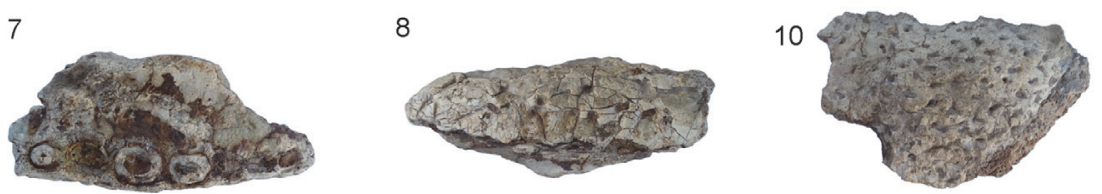

FIGURE 8. Photographs of Globidentosuchus brachyrostris (AMU-CURS-067). 1-3, left ramus of lower jaw in lateral (1), medial (2), and dorsal (3) view. 4-6, anterior, portion of right ramus in lateral (4), medial (5), and dorsal (6) view. $\mathbf{7 , 8}$, fragment of a (right?) maxilla in ventral (7) and lateral (8) view. 9, 10, Fragment of a (left?) premaxilla in ventral (9) and dorsal (10) view. 11, indeterminate cranial fragment found associated with the other skeletal element and therefore referred to the same specimen.

manines with deep jaws and robust dentition. Based on comparison with the type material of Globidentosuchus brachyrostris and the newly referred specimen AMU-CURS-067 described above, specimens AMU-CURS-083, -084 and UNEFM- VF-017 likely belong to the same taxon. However, we use "confer" in classifying these latter specimens because, although the splenial partici- pates in the symphysis, the material is otherwise fragmentary. The material differs from the Peruvian material of Gnatusuchus pebasensis, the other Miocene taxon in which the splenial participates in the symphysis, in the shape of the mandibles, the size and shape of the dentary alveoli, and in having less procumbent teeth. 
1

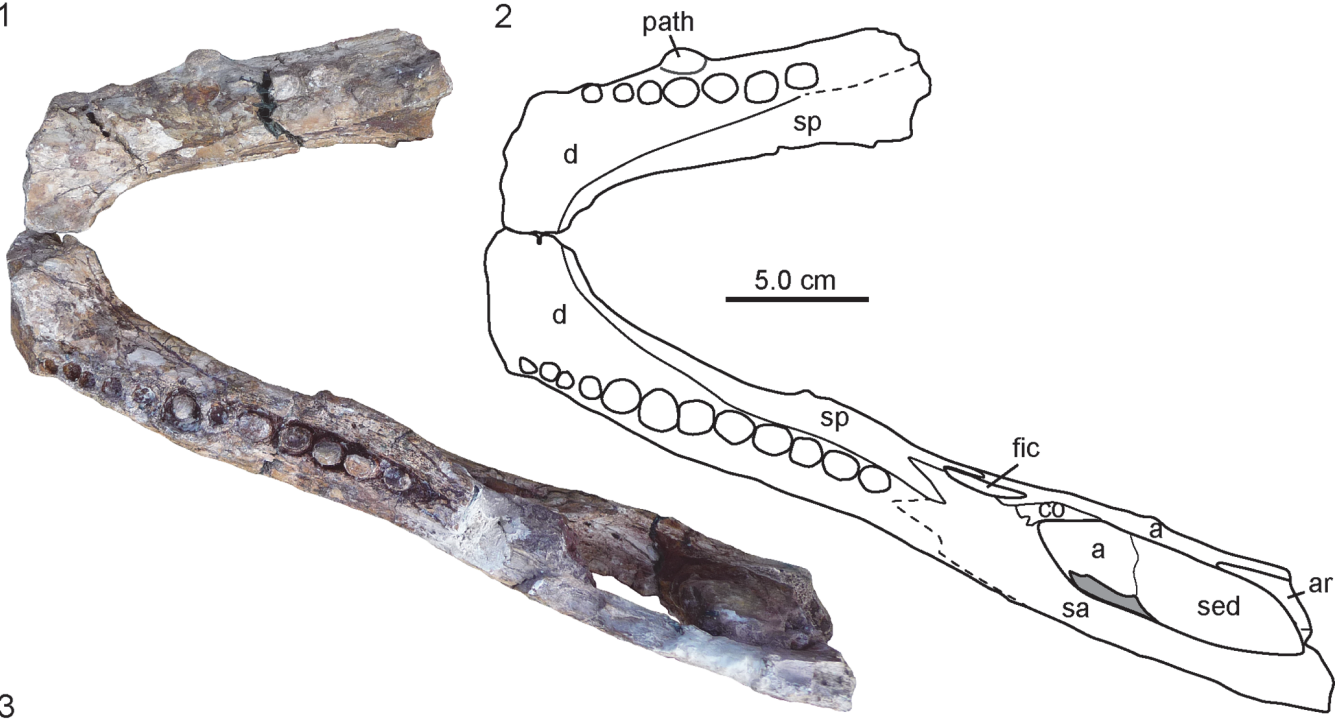

3

4

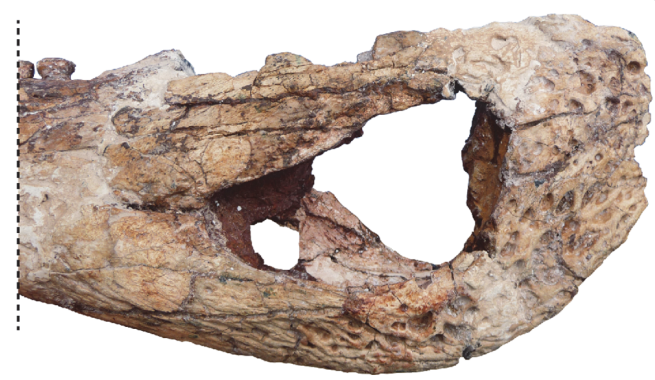

4

5

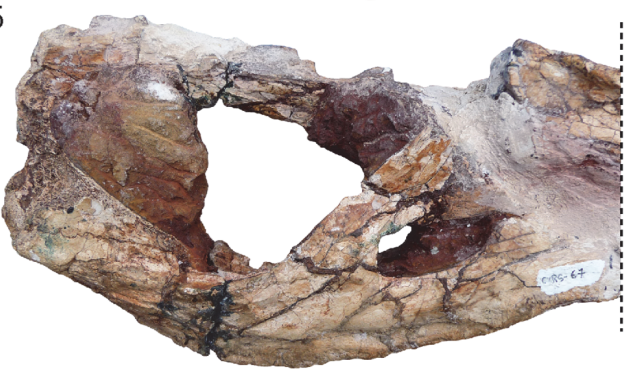

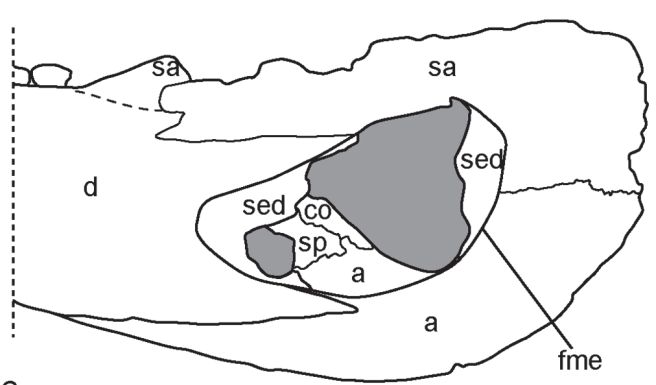

6

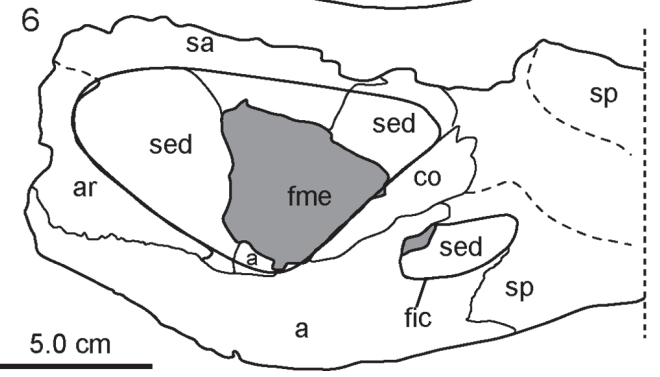

FIGURE 9. Photographs and interpretative drawings of Globidentosuchus brachyrostris lower jaw (AMU-CURS067). 1, 2, assembled right and left ramus in dorsal view showing posterior crushing dentition and the splenials participating in symphysis. 3, 4, posterior part of left ramus in lateral view. 5, 6, posterior part of left ramus in medial view. Note that fragment of articular is still partially present, articulating with the angular ventrally. Abbreviations: a, angular; ar, articular; co, coronoid; d, dentary; fic, foramen intermandibularis caudalis; fme; external mandibular fenestra; path, area of pathology; sa, surangular; sed, sediment; sp, splenial.

The so far best-preserved material thus assigned herein to Globidentosuchus cf. G. brachirostris derives from a locally restricted coquina layer at the Bejucal Creek locality, ca. $500 \mathrm{~m}$ south of Urumaco town, in which the usually disarticulated bones and teeth are black to dark brown in colour. It also lacks any gypsum crystal crusts or infillings, which cause the most severe preservational biases of vertebrate fossils in the Urumaco Formation. The material assigned to G. cf. G. brachyrostris thus includes (Figure 10): AMUCURS-083, an associated left and right dentary and one isolated right dentary (Figure 10.1-6); and AMU-CURS-084, one right maxilla (in two fragments with a neat contact fracture and therefore belonging to the same element), one right angular fragment, one left articular sutured to the surangular, one right surangular sutured to a posterior portion of a dentary, an isolated right surangular, as well as two isolated teeth (Figure 10.7-18). 


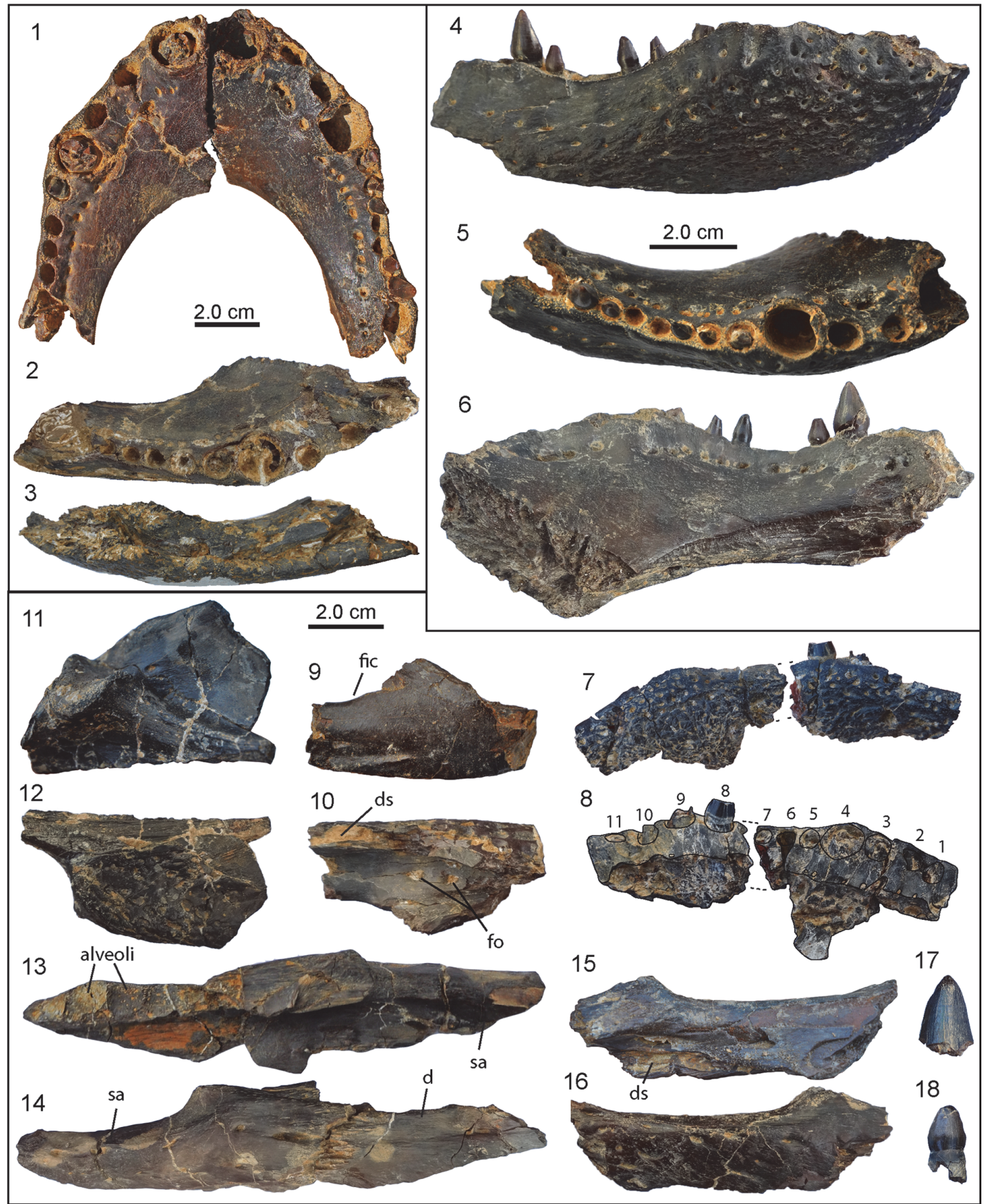

FIGURE 10. Photographs of Globidentosuchus cf. G. brachyrostris. 1-6, AMU-CURS-083. 7-18, AMU-CURS-084. 1, articulated left and right associated dentary in dorsal view. 2, 3, isolated right dentary in dorsal and angled medial view. 4-6, right dentary of (1) in lateral (4), dorsolateral (5) and angled medial view (6). 7, 8, right maxilla in angled lateral and angled medial view. 9, 10, right angular in medial and dorsal view. 11, 12, left articular and portion of surangular in angled medial and lateral view. 13, 14, right surangular sutured to part of dentary in angled medial and lateral view. 15, 16, left surangular in medial and lateral view. 17, 18, teeth. Abbreviations: d, dentary; ds, scar for dentary articulation; fic; foramen intermandibularis caudalis; fo, foramen; sa, surangular. 
One right and one of the left dentaries were not only found in close proximity to each other but they belong to the same specimen because their symphyseal suture is clearly complementary (Figure 10.1). The right one (Figure 10.4-6) preserves the first 12 alveoli and half of the thirteenth; the left preserves the first nine and a half alveoli. The alveolus length - width (and interalveolar length) are reported in millimetres for these two dentaries (note that * indicates approximation): right dentary: ?-10.6 (4.4); 6.6-5.4 (4.5); 7.4-6.1 (3.1*); 11.6*-12.0 (1.9); 7.3-6.0 (2.0); 5.5*-5.0 (?); 6.4*-4.7(?); 4.5-4.0 $\left(2.1^{*}\right)$; 4.0-4.0 (?); 4.5*-4.1* (?); ?-? (?); ?-7.9. Left dentary: $11.0^{*}-10.9^{*}(5.9) ; 8.9-6.1$ (6.0); 7.0-5.5 (2.0*); 11.1-? (2.2); 7.4-7.1 (5.0); 6.3-4.9 (2.0); 5.24.3 (1.6); $5.0^{*}-4.4$ (2.3). In lateral view, the dorsal edge of the dentary is undulated, with convexities corresponding to the first and fourth alveolus and the deepest point of the concavities corresponding to the second interalveolar space and the seventh alveolus. The splenial scar clearly indicates that this element was involved in the symphysis. In all the three specimens the dentary symphysis reaches the anterior edge of the seventh tooth (the splenial was probably rather thin and therefore it did not considerably increase the anteroposterior thickness of the symphysis). The Meckelian canal of the right and left dentaries belonging to the same specimen (Figure 10.1) is equally narrow in the anterior portion of the dentary, and placed closer to the ventral than to the dorsal edge of the dentary. The other right dentary (Figure 10.2-3) apparently has a much broader Meckelian canal, although this specimen experienced some crushing that could have widened the canal. The symphysis is broad (up to about $46 \mathrm{~mm}$ in the left dentary), long (about $55 \mathrm{~mm}$ ), and relatively thin (22 $\mathrm{mm}$ ). Several small (much smaller than the alveoli), deep foramina are aligned medially to the tooth row.

The poorly preserved maxilla corresponds to the first 11 alveoli (Figure 10.7-8). In lateral view, it is rather flat and the ventral edge is undulated, with a ventral convexity corresponding to approximately the middle of the preserved portion of the maxilla. The fourth alveolus is the largest of the preserved series, but precise sizes of the alveoli cannot be measured because of preservational reasons. Tooth fragments are present in the alveoli 2, 8-10 and even if not complete, they seem to be quite slender and labiolingually compressed. Welldefined occlusal pits are present medially to the fifth alveolus (and the fifth interalveolar space), the sixth interalveolar space (and the seventh alveo- lus), and the tenth interalveolar space (and eleventh alveolus).

The right angular fragment (Figure 10.9-10) preserves the anterior portion of the bone, so the articulation with the surangular and articular are not preserved. Anteriorly on the medial side, part of the ventral and posterior border of the foramen intermandibularis caudalis is preserved, whereas dorsally the scar for the articulation with the dentary is visible. Furthermore, two foramina are visible dorsally within the Meckelian groove.

In the fragment preserving the left articular and surangular (Figure 10.11-12), the articular surangular suture is nearly rectilinear in the glenoid fossa when seen in dorsal view (it is only slightly bowed) and is rather simple ventrally to the fossa. The largest foramen in the area of the angular/ articular suture opens on the surangular only (very close to the glenoid fossa) and could represent the lingual foramen for the articular artery. There is no marked sulcus on the anterior face of the articular. The posterior tip of the retroarticular process has broken off.

The posterior portion of a right dentary (sutured to surangular; the contact surfaces with the anterior portion of the available dentaries are not preserved; Figure 10.13-14) hosts the lateral wall of the last six alveoli, which are clearly very large (probably up to at least $10 \mathrm{~mm}$ long) if compared to most of the anterior alveoli preserved in the other remains. The size of the alveoli slightly decreases towards the back of the row, but the last alveolus is nevertheless rather large. It seems that the medial wall of the alveoli was formed by the missing splenial. Also the other posterior portion of a right dentary shows the presence of enlarged alveoli. This dentary fragment is associated to a part of the corresponding surangular showing the smooth and widened dorsal edge. The isolated right surangular fragment (Figure 10.15-16) preserves only the portion roofing the external mandibular fenestra. Anteriorly the contact to the dentary is not visible. The dorsal surface and the anterior portion of the lateral surface is smooth, whereas the posterior portion of the lateral surface shows pitting and foramina. Medially the scar for the articulation with the dentary is observable.

The best preserved right dentary (Figure 10.46) still hosts teeth in the fifth to seventh, tenth and eleventh alveoli. All these teeth are slender and pointed; labiolingually compressed, with an evident mesiodistal carina; the crown is slightly constricted at the base. The base of the eleventh tooth is 6.6 $\mathrm{mm}$ long and $5.2 \mathrm{~mm}$ broad, the crown $10.6 \mathrm{~mm}$ 

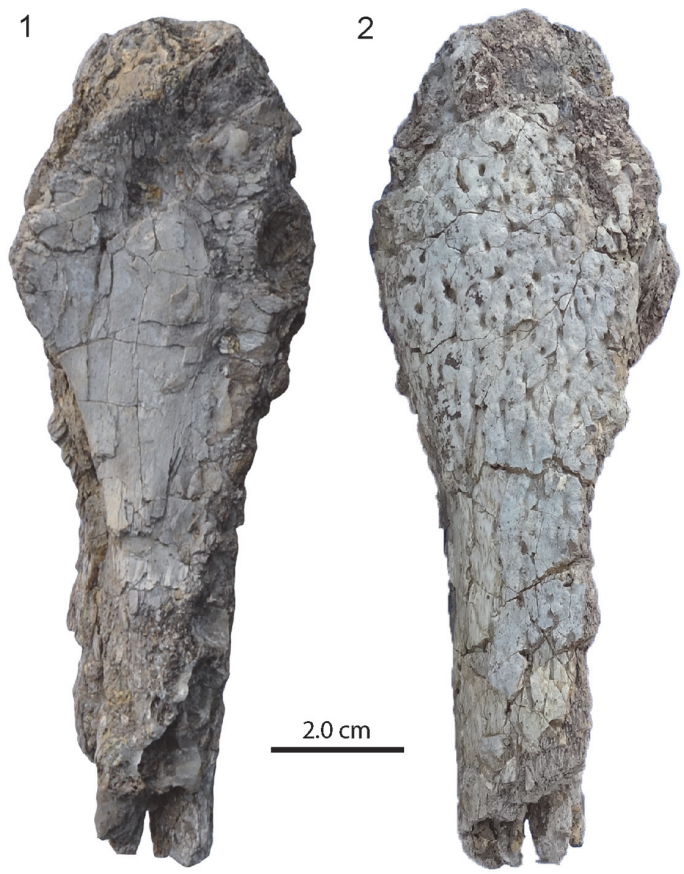

5
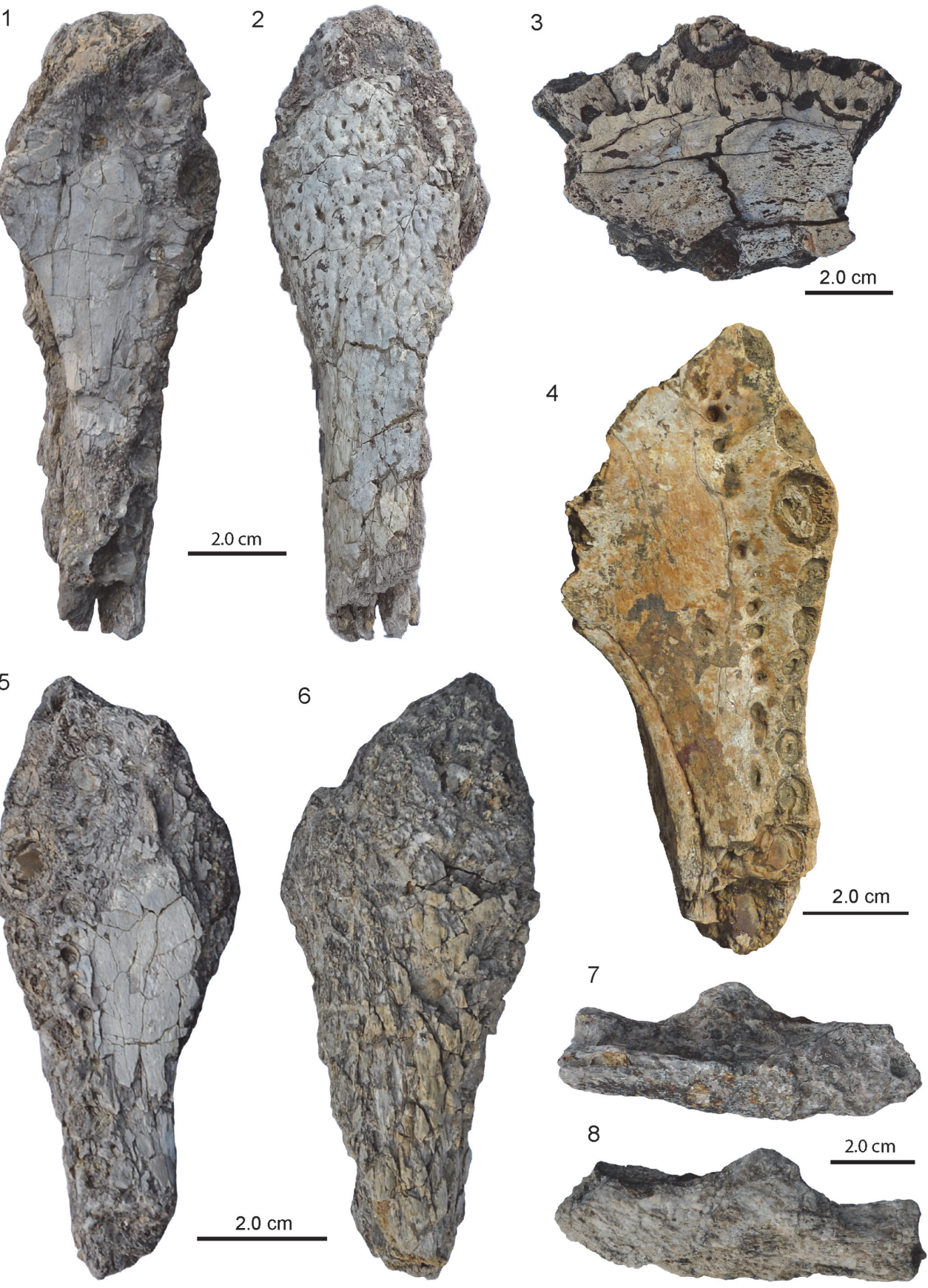

FIGURE 11. Images of Globidentosuchus cf. G. brachyrostris (UNEFM-VF-017) including three right dentaries (1-4), one left dentary $(5,6)$, and one left angular in angled dorsal (7) and medial (8) view. Images of dentaries in 3, 4, and 5 in dorsal view, 2 and $\mathbf{6}$ in ventral view. Note splenial associated with dentary and reaching the symphysis in (4).

tall. Two isolated teeth (Figure 10.17-18) associated with this material are bigger in size but not blunt, with the larger of the two having a wrinkled surface and the smaller also showing a constriction of the crown at the base. It remains unclear whether these teeth belonged to the skull or the mandibles.
Finally, the material of UNEFM-VF-017 (El Hatillo locality, lower Upper Member, Urumaco Fm.) includes (Figure 11): three right dentaries (Figure 11.1-4; one associated with its splenial) and one left dentary (Figure 11.5-6), as well as one left angular (Figure 11.7-8). Compared to the Bejucal Creek specimens, those from El Hatillo are mostly whitish or cream-coloured and one is light 
1
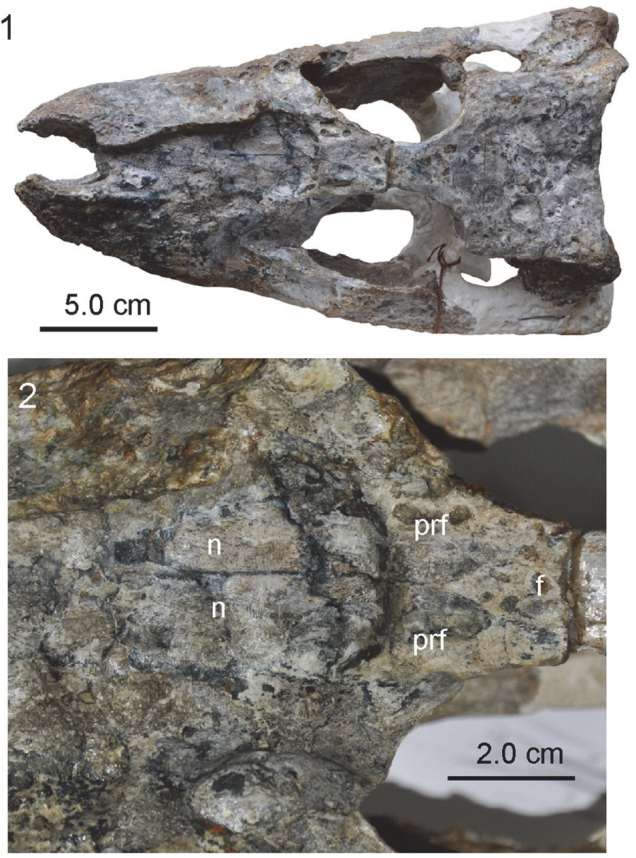

3

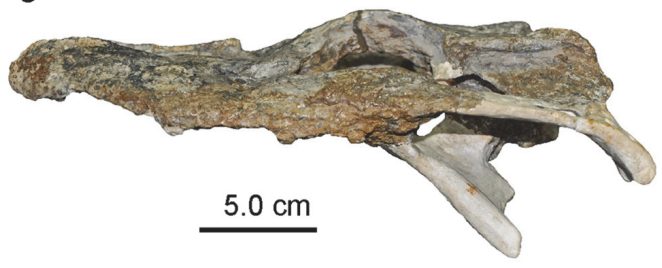

4

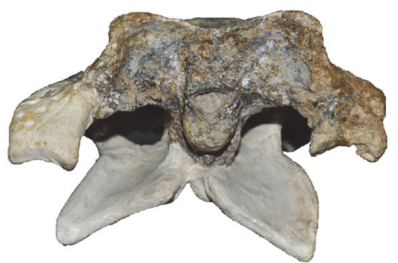

5
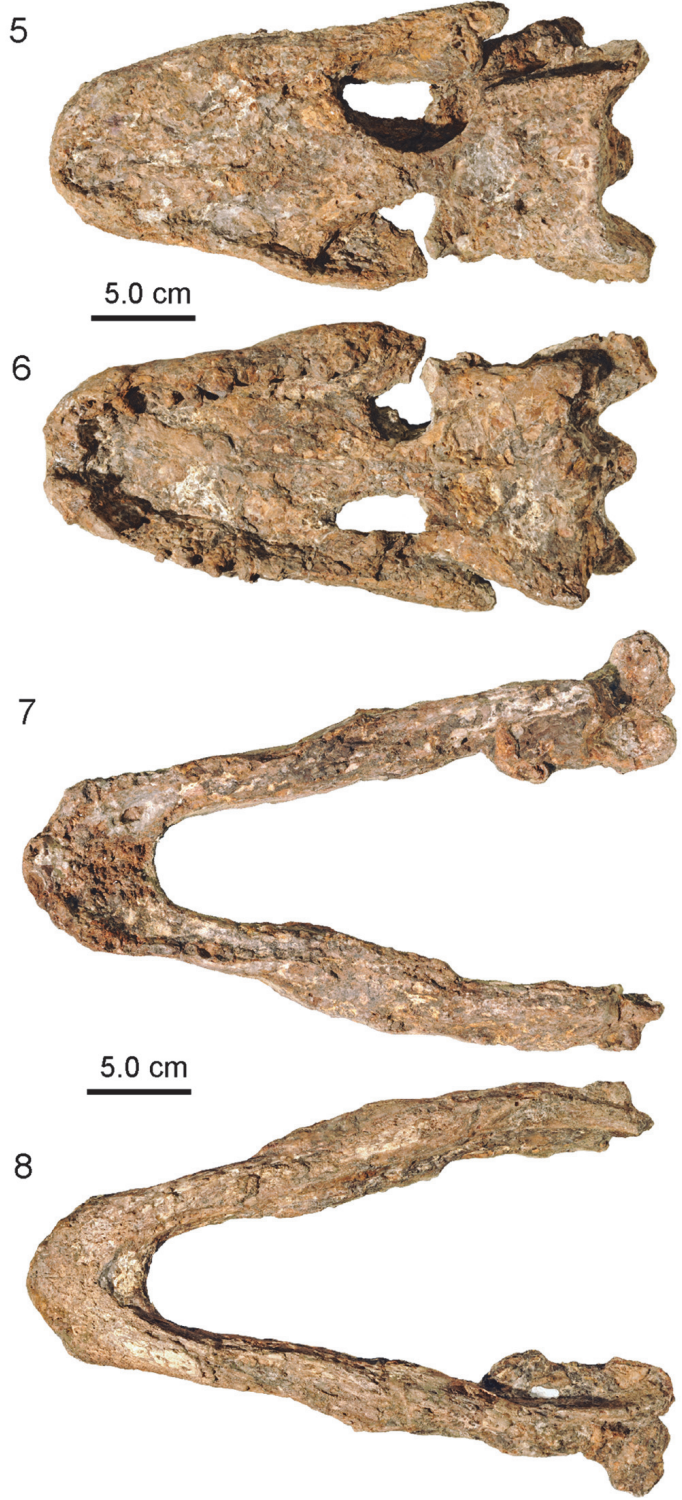

FIGURE 12. Photographs of the holotype skull of Melanosuchus fisheri (MCNC-243; 1-4) and the skull and associated lower jaw assignable to Caimaninae aff. Melanosuchus fisheri (AMU-CURS-234, 5-8). 1, skull in dorsal view. 2, close-up of the sutures between the frontal, prefrontals and posterior portion of nasals. Compare to interpretative drawing in Figure 4.1. 3, skull in left lateral view. 4, skull in occipital view. 5, 6, skull in dorsal and ventral view. 7, 8, lower jaw in dorsal and ventral view. Abbreviations: $f$, frontal; $n$, nasal; prf, prefrontal.

brownish in colour. The morphology of the incomplete dentaries from El Hatillo is fully congruent with that of the dentaries described from Bejucal Creek above. The best preserved element is the right dentary associated with the splenial (Figure 11.4; both light brownish in colour). The alveoli from 2 to 11 are present, but a section of the first alveolus is visible along the anterior fracture. The fourth alveolus (the third preserved) is by far the largest. The splenial is relatively massive, being up to $4.2 \mathrm{~mm}$ thick. Its anterior tip clearly reaches the symphyseal area (at the level of the seventh alveolus) where it splits into two branches. Even considering that they could be only partially preserved, the lower branch seems to be the smallest and the shortest. It does not develop any sutural surface for the left splenial. Conversely the dorsal branch has an irregular surface that indicates at least a modest involvement in the jaw symphysis. The possible left angular (Figure 11.7-8) does not provide additional information because of preservational reasons. 
Genus MELANOSUCHUS Gray, 1862

Caimaninae aff. Melanosuchus fisheri Medina, 1976

The genus Melanosuchus was described by Gray (1862), to accommodate the living black caiman Melanosuchus niger (Spix, 1825) as type species. Medina (1976) described Melanosuchus fisheri based on two fossils from the Urumaco Formation (at the time thought to be Pliocene in age) of Falcón State, Venezuela. The holotype skull MCNC-243 (Figure 12.1-4) and one referred skull, MCZ 4336, both are only partly preserved and suffered some distortion. Medina (1976) mentioned that $M$. fisheri would represent the first fossil record of the genus and that it is also distinct from the living species M. niger (Spix, 1825). The revision of the type material of $M$. fisheri is currently the subject of a further specific contribution on the South American crocodylians, for which we will refrain from adding to its osteological description here.

An additional specimen from Urumaco, AMUCURS-234 (Figure 12.5-8), consists of an almost complete skull and associated lower jaw. It was found at the El Hatillo locality, associated with few postcranial remains, within the lowest part of the Upper Member of the Urumaco Formation. The specimen was previously recognised as Melanosuchus fisheri (Scheyer et al., 2013), but re-examination showed a lack of clear sutures of the skull and mandible bones. It shares however the slender, triangular skull shape with the holotype, and it lacks closely spaced crushing teeth in the posterior part of the mandibles. The lower jaws are long and gracile. The skull is otherwise dorsoventrally compacted and the quadratojugals and quadrates are missing on both sides, whereas the jugals are damaged and missing the posterior section. The lower jaw consists of both rami in articulation, but the latter are damaged posterior to the craniomandibular articulation with the articular and angular and retroarticular process being incompletely (right side) or not preserved (left side).

Genus MOURASUCHUS Price, 1964

Mourasuchus arendsi Bocquentin-Villanueva, 1984 Mourasuchus nativus (Gasparini, 1985)

The type species of Mourasuchus, M. amazonensis, was described in Price (1964) based on cranial remains from the late Miocene Solimões Formation, Acre, Brazil. Mourasuchus (Nettosuchus) atopus has been described from the middle Miocene La Venta fauna, Colombia (Langston, 1965, 1966) and is now also known from the Pebas system, Iquitos area, Peru (Salas-Gismondi,
2015), M. arendsi from the Urumaco Formation, Venezuela (Bocquentin Villanueva, 1984), and $M$. nativus from late Miocene of Argentina (Gasparini, 1985). The latter species is based on material from the late Miocene Ituzaingó Formation ("Conglomerado Osífero") of Paraná, Argentina and was originally described as Carandaisuchus nativus (Gasparini, 1985), based mainly on the presence of squamosal "horns", herein referred to as squamosal eminences. It was later synonymised with Mourasuchus based on Brazilian material from Acre (Bocquentin and Souza Filho, 1990). Although published earlier, the description of $M$. arendsi from Venezuela was not noted or referenced in the description of $M$. nativus (Gasparini, 1985). The most detailed anatomical study of $M$. nativus cranial material to date, including the holotype MLP 73-IV-15-8, was given by Bona et al. (2013a). Scheyer et al. (2013) noted and partially described skull remains (AMU-CURS-212 and 218) of $M$. nativus from the Middle and Upper Member of the Urumaco Formation, mainly based on the pronounced squamosal eminences and a posterior median ridge on the parietal. Specimen UNEFM-CIAAP-1333, a right maxilla from the type locality of $M$. arendsi, noted by Bocquentin Villanueva (1984) could currently not be located. Additional cranial material, assigned to Mourasuchus, is known from the middle Miocene Fitzcarrald Arch, Peru (Salas-Gismondi et al., 2007; Salas-Gismondi, 2015) and the late Miocene Yecua Formation in Bolivia (Tineo et al., 2015). The record of Mourasuchus from the Pleistocene of Tarija, Bolivia (e.g., Bocquentin and Souza Filho, 1990; Aguilera, 2004), however, remains doubtful.

The holotype of Mourasuchus arendsi (UNEFM-CIAAP-1297) consists of a skull, associated with the right ramus and a fragment of left ramus of a lower jaw (Figure 13), as well as some additional postcranial remains including the anterior portion of the cervical vertebral column in natural position up to the sixth cervical vertebra (Bocquentin Villanueva, 1984). In the original description interpretative line drawings of the skull in dorsal, ventral, and occipital view were given, however, pictures of the actual specimen were not included. Our revision of the type material yields some important differences to the original description. Unfortunately, we were not able to study the ventral side of the skull due to the fragile status the specimen is in.

The skull roof of UNEFM-CIAAP-1297 is small, showing also small sized, sub-circular supratemporal fenestrae, the anterior (rostral) bor- 

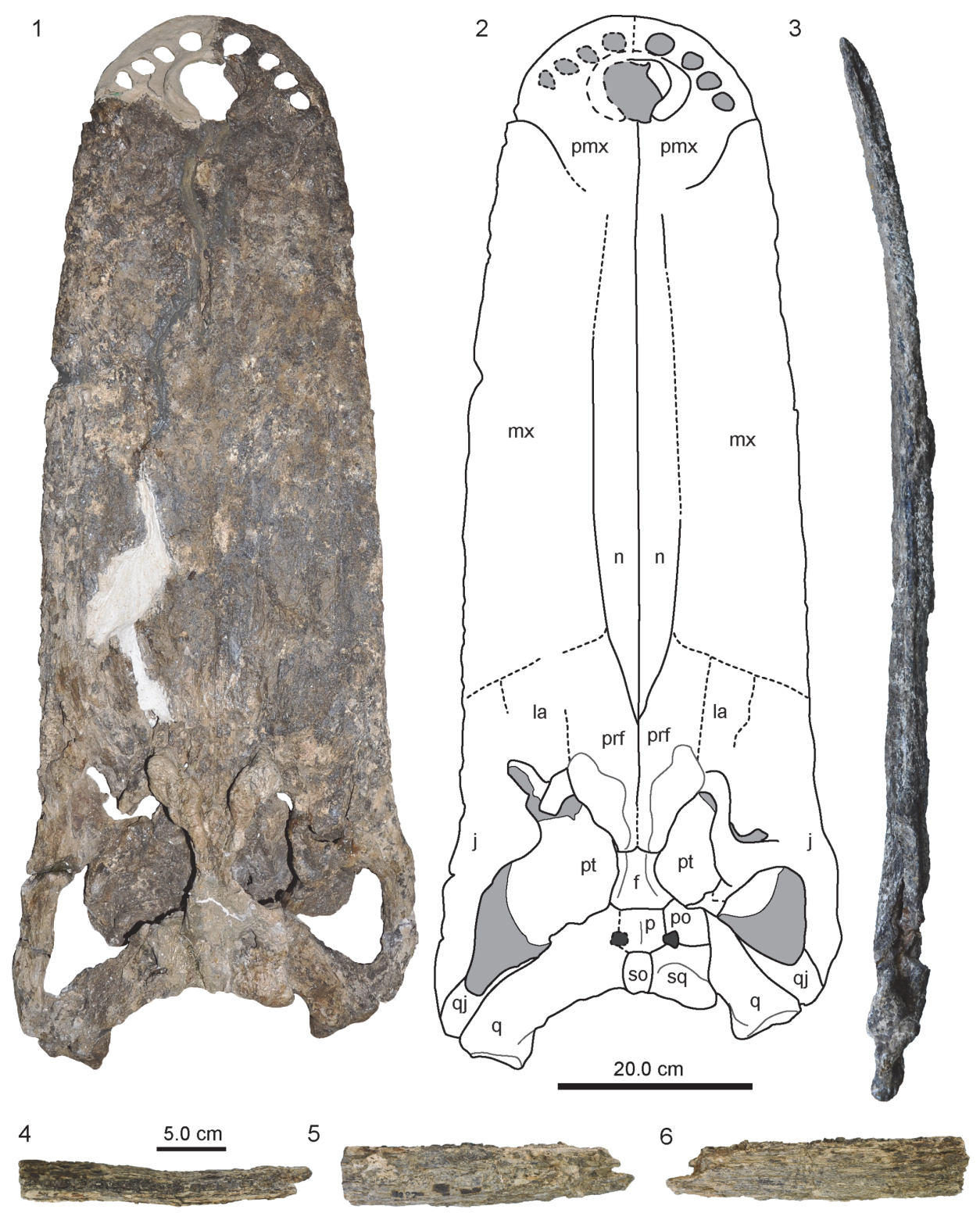

FIGURE 13. Photographs $(1,3,4-6)$ and interpretative drawing (2) of the holotype skull and associated lower jaw remains (UNEFM-CIAAP-1297) (3) of Mourasuchus arendsi. 1, 2, skull in dorsal view. 3, right mandibular ramus in dorsal view. 4-6, Fragment of left mandibular ramus in dorsal (4), medial (5) and lateral (6) view. Abbreviations: $f$, frontal; j, jugal; la, lacrimal; mx, maxilla; n, nasal; p, parietal; pmx, premaxilla; po, postorbital; prf, prefrontal; pt, pterygoid; q, quadrate; qj, quadratojugal; so, supraoccipital; sq, squamosal.

der of which is formed by the parietal and the postorbital (Figure 13.1-2). The postorbital-squamosal suture enters the supratemporal fenestra laterally and not posterolaterally as proposed by Bocquentin Villanueva (1984). The postorbitals thus have a rectangular shape. The supratemporal is prominently exposed on the skull roof and resides in a v-shaped valley between the squamosals, which exhibit strong squamosal eminences. These eminences (Figure 14) are, however, either slightly eroded (right side) or broken off completely (left side). If reconstructed, they form a much more pronounced incised median $V$-shaped valley of the posterior skull margin in occipital view. The parietal carries a median crest posteriorly (Figure 14). Interestingly the crest was also indicated graphically by Bocquentin Villanueva (1984, figure 1A), but it was not further described in the text. The frontal is shorter than previously reconstructed without a large anterior process (as is the case for example in UFAC-1424, see Bocquentin and Souza Filho, 1990; Bona, et al., 2013a). The fron- 

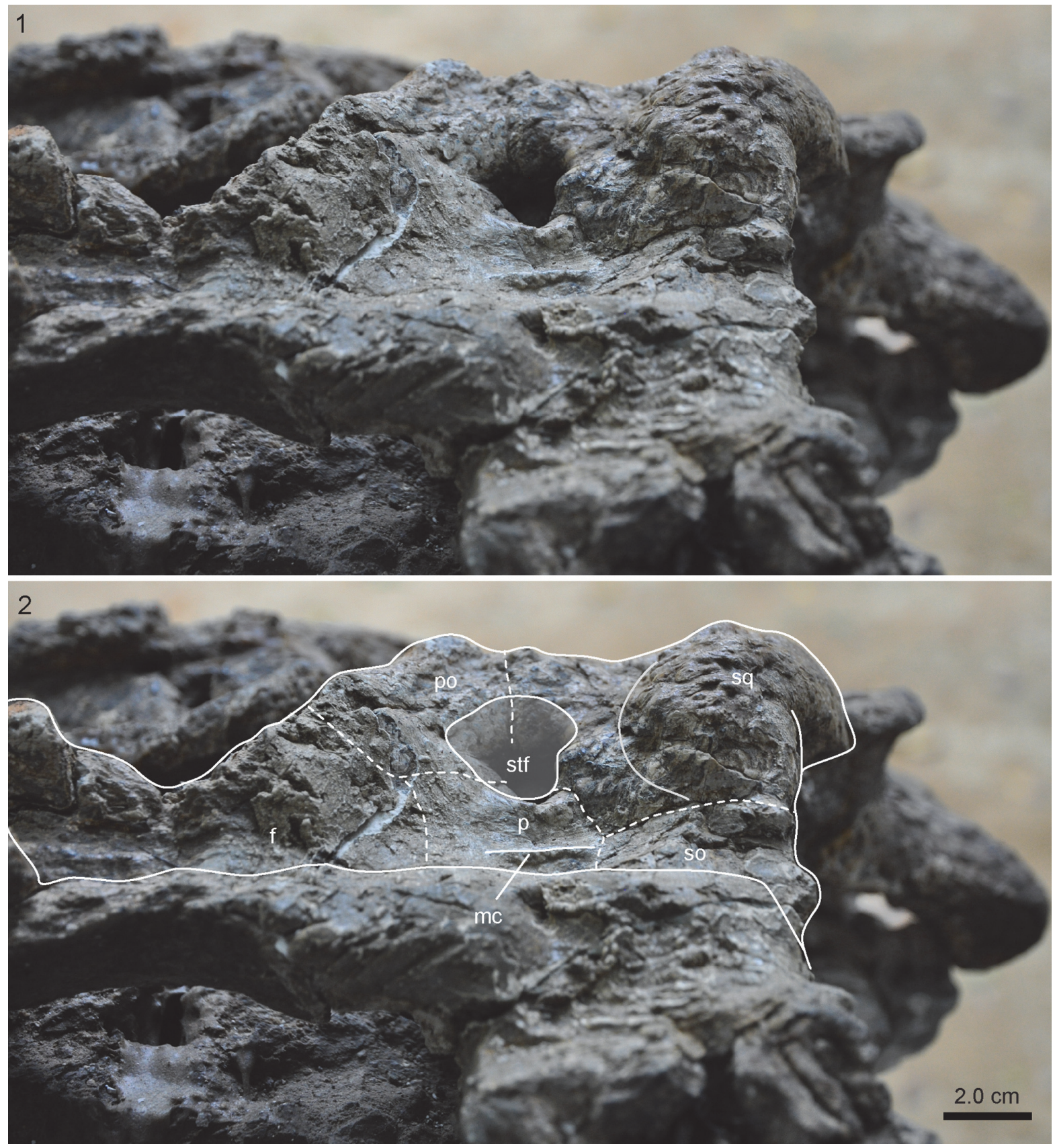

FIGURE 14. Photograph without (1) and with superimposed interpretative drawing (2) of the skull roof of holotype skull (UNEFM-CIAAP-1297) of Mourasuchus arendsi in left dorsolateral view. Abbreviations: $f$, frontal; mc, medial crest on parietal; p, parietal; po, postorbital; so, supraoccipital; sq, squamosal; stf, supratemporal fenestra.

tal-prefrontal suture thus lies at mid-orbit level, just at the posterior extend of the prominent orbital knobs of the prefrontals. The prefrontal bones meet broadly medially for most of their anteroposterior extend before articulating with the nasals in a Vshaped suture. The anterior-most extent of the prefrontals, the lacrimals, and the jugals is not clear. The maxilla has a rectangular outline posteriorly. In dorsal view, the jugal does not show a clear notch as in Mourasuchus amazonensis, due to cracks in UNEFM-CIAAP-1297. There is, however, a bend of the ventral edge of the right jugal in lateral view (Figure 15; for preservational reasons the left side does not show the original morphology). There is clear evidence that the posterior portion of the right jugal, quadratojugal, and quadrate has been separated by a system of fractures from the rest of the skull and was tilted downwards. If the bones are 

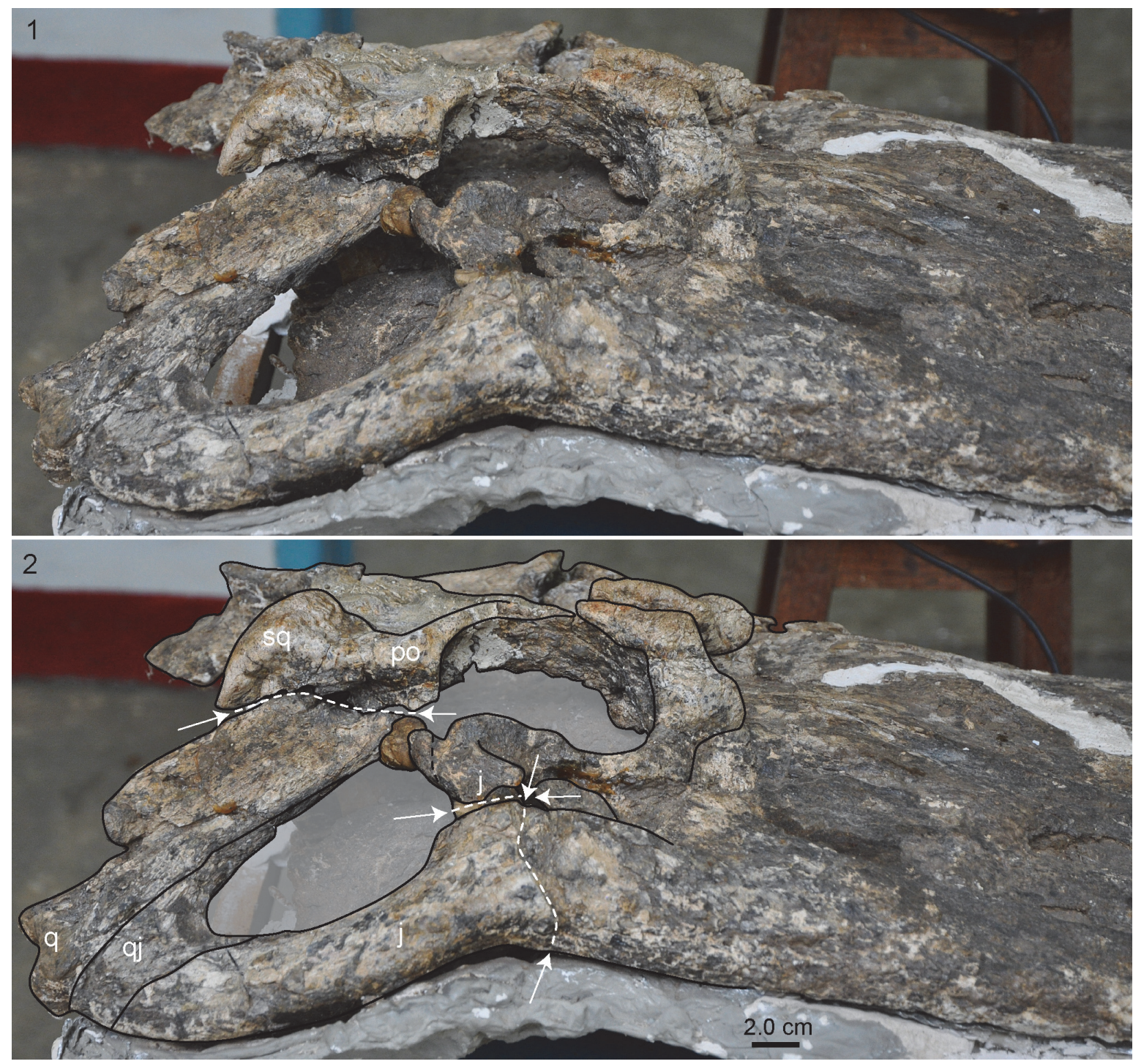

FIGURE 15. Photograph without (1) and with superimposed interpretative drawing (2) of the right side of the posterior portion of holotype skull (UNEFM-CIAAP-1297) of Mourasuchus arendsi in angled lateral view. Note clear notch of jugal and system of cracks (indicated by dotted white lines and arrows) leading to displacement of right posterolateral portion of skull. Abbreviations: j, jugal; po, postorbital; q, quadrate; qj, quadratojugal; sq, squamosal.

virtually relocated (moving of the actual bones was not possible and might result in a partial collapse of the specimen in its present state) into their original position, the notch becomes more pronounced in dorsal view. The jugal bars of UNEFM-CIAAP-1297 are round in cross section. The suture between the nasals, the maxillae, and the premaxillae is obscured anteriorly, so that it is questionable whether the premaxillae meet in a median posterior process as proposed by Bocquentin Villanueva (1984), or whether the premaxillae show two processes framing the nasals laterally, thus forming a $\mathrm{W}$-shaped suture (as is present in $M$. amazonensis, see Langston, 1966). The premaxillae show a raised rim around the external naris. In addition there are four perforations anteriorly and laterally to the external naris, which accommodated the four enlarged anterior-most teeth in the lower jaws. In occipital view (Figure 16), the skull shows more dorsolateral compaction than was initially indicated by Bocquentin Villanueva (1984), but the right squamosal eminence is well discernible. The quadrates show sutural scars on their dorsal surface for the posterior-most parts of the exoccipitals and the squamosals, which are partially broken off. The occipital condyle is round, and the basioccipital dorsolaterally carries prominent sutural scars for the exoccipital pillars. It cannot be discerned if the 

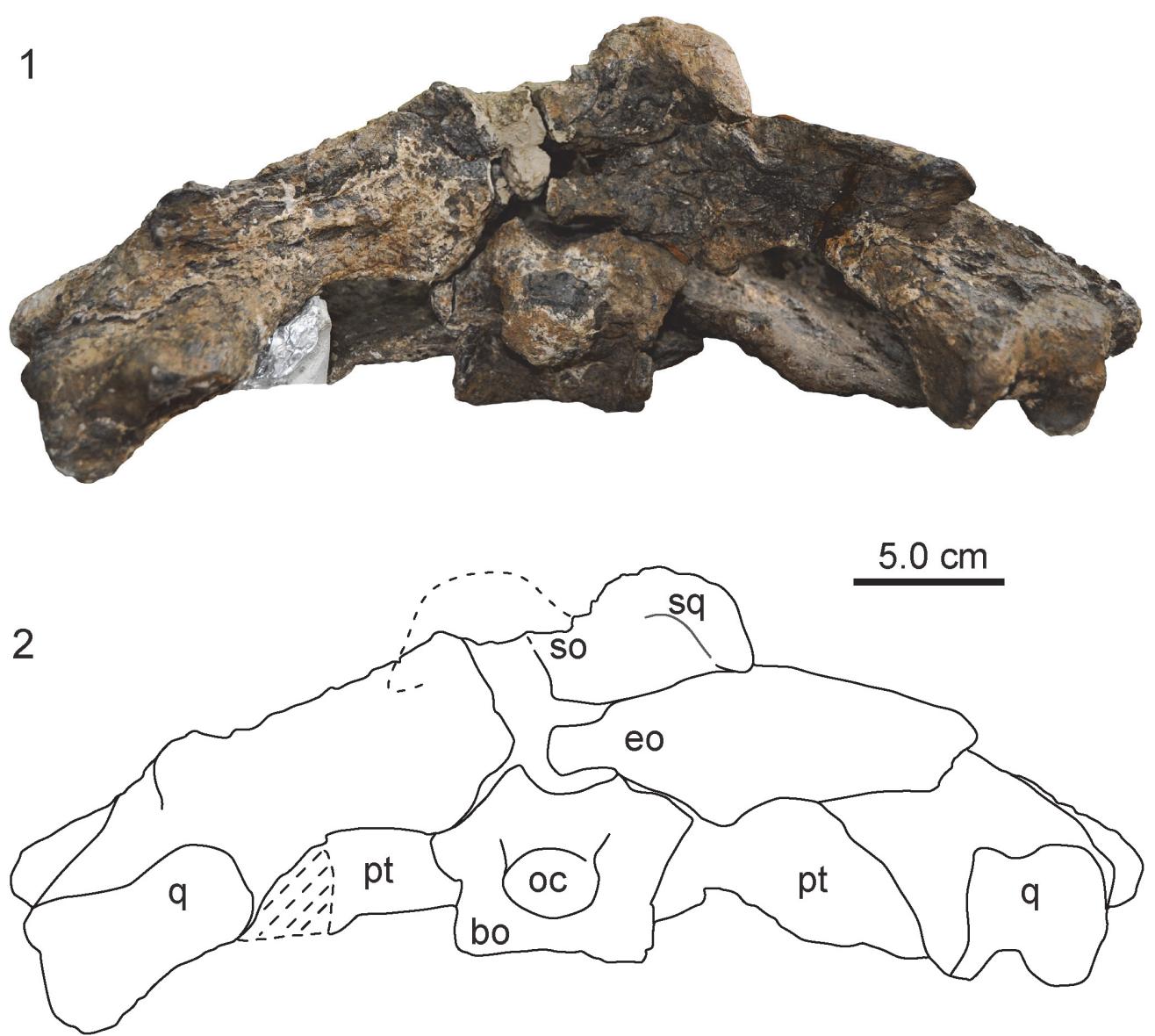

FIGURE 16. Photograph (1) and interpretative drawing (2) of the holotype skull (UNEFM-CIAAP-1297) of Mourasuchus arendsi in occipital view. Note dorsoventral compaction of specimen. Abbreviations: bo, basioccipital; eo, exoccipital; oc, occipital condyle; pt, pterygoid; q, quadrate; so, supraoccipital; sq, squamosal.

exoccipitals sent thin processes laterally to the basioccipital tubera. The lower jaw remains of $M$. arendsi were not figured in the original description (Bocquentin Villanueva, 1984), but photographs of the right lower jaw ramus in lateral view were later included by Aguilera (2004) and Sánchez-Villagra and Aguilera (2006). Bocquentin Villanueva (1984) noted that the lower jaw of $M$. arendsi essentially resembles that of $M$. atopus as described by Langston (1965). Aguilera (2004) added that the large jaw of $M$. arendsi is thin and curved, and the dentary carries at least 32 alveoli in a straight line. In dorsal view, the line of alveoli is straight throughout the posterior part of the dentary (visible as a mineralised or sediment-filled ridge), but individual alveoli are not discernible (Figure 13.3). The surangular is partially broken off, so that the angular and posterior portion of Meckel's groove is visible. Anteriorly, the symphyseal region of the jaw is not preserved.
1) A heavily reconstructed skull and lower jaw of a large specimen (MCNC-URU-110-72V ="MCNURU-2002-110" of Aguilera, 2004), of which Langston (2008) described associated postcranial remains (all labelled as "MCC-110-72V"). Much of the skull roof, the orbital region, and parts of the maxillae and premaxillae, as well as of the palate and dentary have been modelled in plaster (Figure 17.1-2), for which we only tentatively suggest assignment of this specimen to Mourasuchus arendsi. The maxillae are slightly convergent and do not extend parallel to each other as in $M$. atopus. The anterior snout region and the external naris were wrongly reconstructed to resemble $M$. amazonensis at the time, but are here interpreted to be similar to those of the $M$. arendsi holotype. Forty-two plaster-cast teeth are inserted on the right ramus and 38 on the left ramus of the lower jaw. In addition, all alveoli in the upper jaw are covered by plaster-reconstructed teeth. In contrast, the specimen has still a well- preserved occipital region and quadrates, quadratojugals and jugal bones delimiting the large infratemporal fenestrae. The jugals have a 


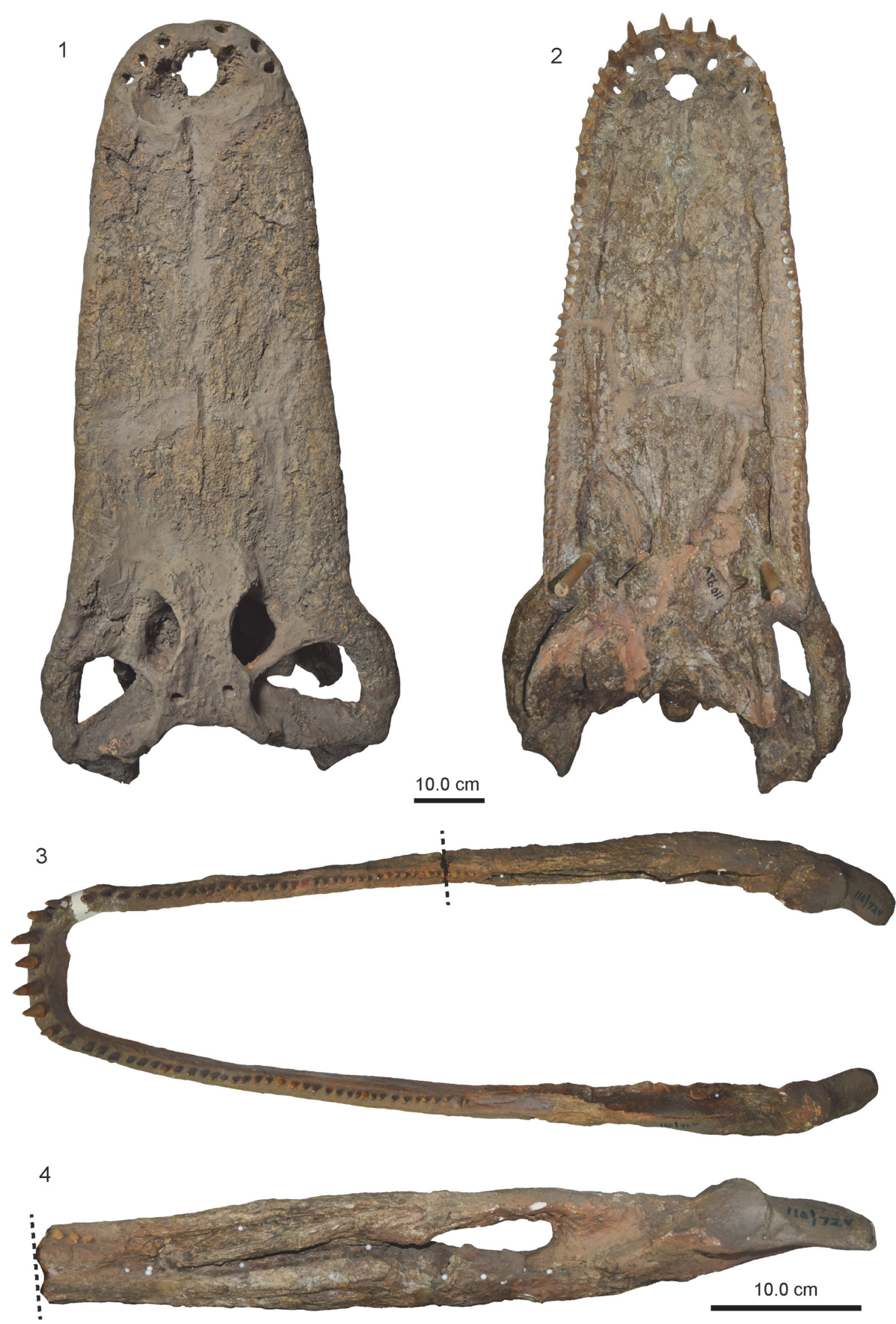

FIGURE 17. Photographs of skull and lower jaw (MCNC-URU-110-72V) assignable to Mourasuchus arendsi . 1, dorsal view. 2, ventral view. 3, dorsal view. 4, medial view. Note that large parts of the specimen have been heavily reconstructed and all tooth alveoli are covered by plaster-cast teeth.

pronounced notch at their lateral edges, as has been described in the holotype of $M$. amazonensis (Price, 1964) and specimen UFAC-1424, assigned to $M$. nativus (Bocquentin and Souza Filho, 1990; Bona et al., 2013a; Tineo et al., 2015). The posterior aspect of the right ramus preserves partially the dentary, whereas the splenial and coronoid are missing so that the Meckel's groove in the dentary is revealed (Figure 17.3-4). The posterior part of the right ramus, including the articular, surangular, and retroarticular process appear to be largely remodelled.

2) A weathered posterior skull fragment (UNEFM-VF03) with pronounced, but partially eroded squamosal eminences, small supratemporal fenestrae (their rostral border being composed of the parietal and 


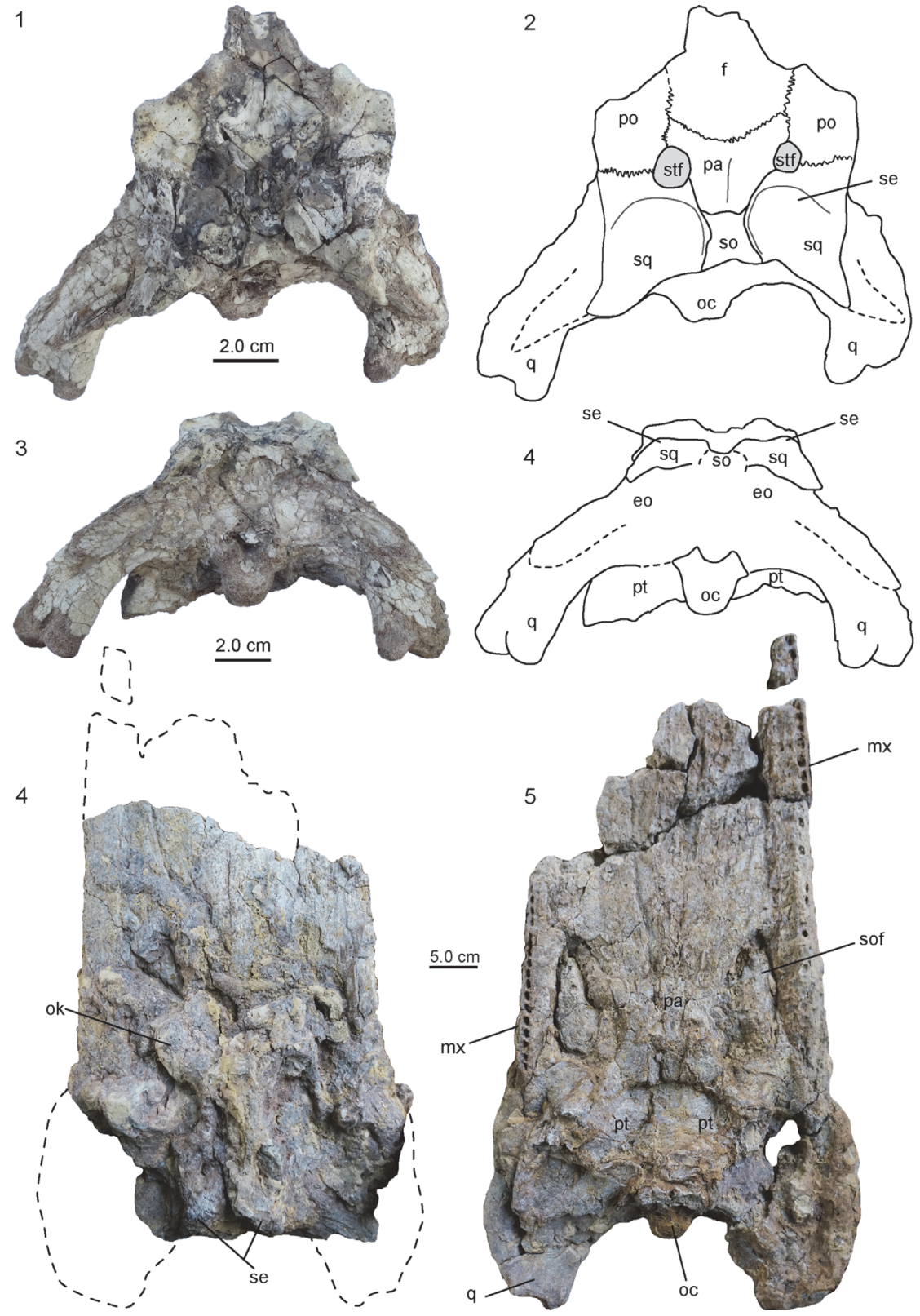

FIGURE 18. Photographs and interpretative drawing of weathered posterior skull portion (UNEFM-VF-03) and large skull part (AMU-CURS-768) of Mourasuchus arendsi. 1, 2, incomplete skull in dorsal view. 3, 4, incomplete skull in occipital view. 5, 6, large porterior skull part in dorsal and ventral view. Note squamosal eminences and posterior median ridge on parietal in UNEFM-VF-03 and both, the squamosal eminences and the knobs in front of the orbits in AMU-CURS-768. Abbreviations: eo, exoccipital $\mathrm{f}$, frontal; $\mathrm{mx}$, maxilla; oc, occipital condyle; ok, ornamental knob on prefrontal; pa, parietal; po, postorbital; pt, pterygoid; q, quadrate; se, squamosal eminences; so, supraoccipital; sof, suborbital fenestra; sq, squamosal; stf, supratemporal fenestra.

the postorbital), and a parietal carrying a medial ridge (Figure 18.1-4). The configuration of the bones and their sutures, as far as preserved, is very similar to that of the holotype skulls of Mourasuchus arendsi (UNEFM-CIAAP-1297) and M. nativus (MLP 73-IV-15-8).

3) A posterior skull part of a large specimen (AMUCURS-768) from El Vijiadero locality in the Lower
Member of the Urumaco Formation, presenting the skull table, occipital region and posterior portion of the rostrum (Figure 18.4-5). The preserved portion of the skull reaches about $65 \mathrm{~cm}$ in length and a maximum width of $40 \mathrm{~cm}$. Dorsally the squamosals show prominent eminences, the jugal has a jugal notch, and there are ornamental knobs present on the prefrontals. Ventrally the palatines separate the 

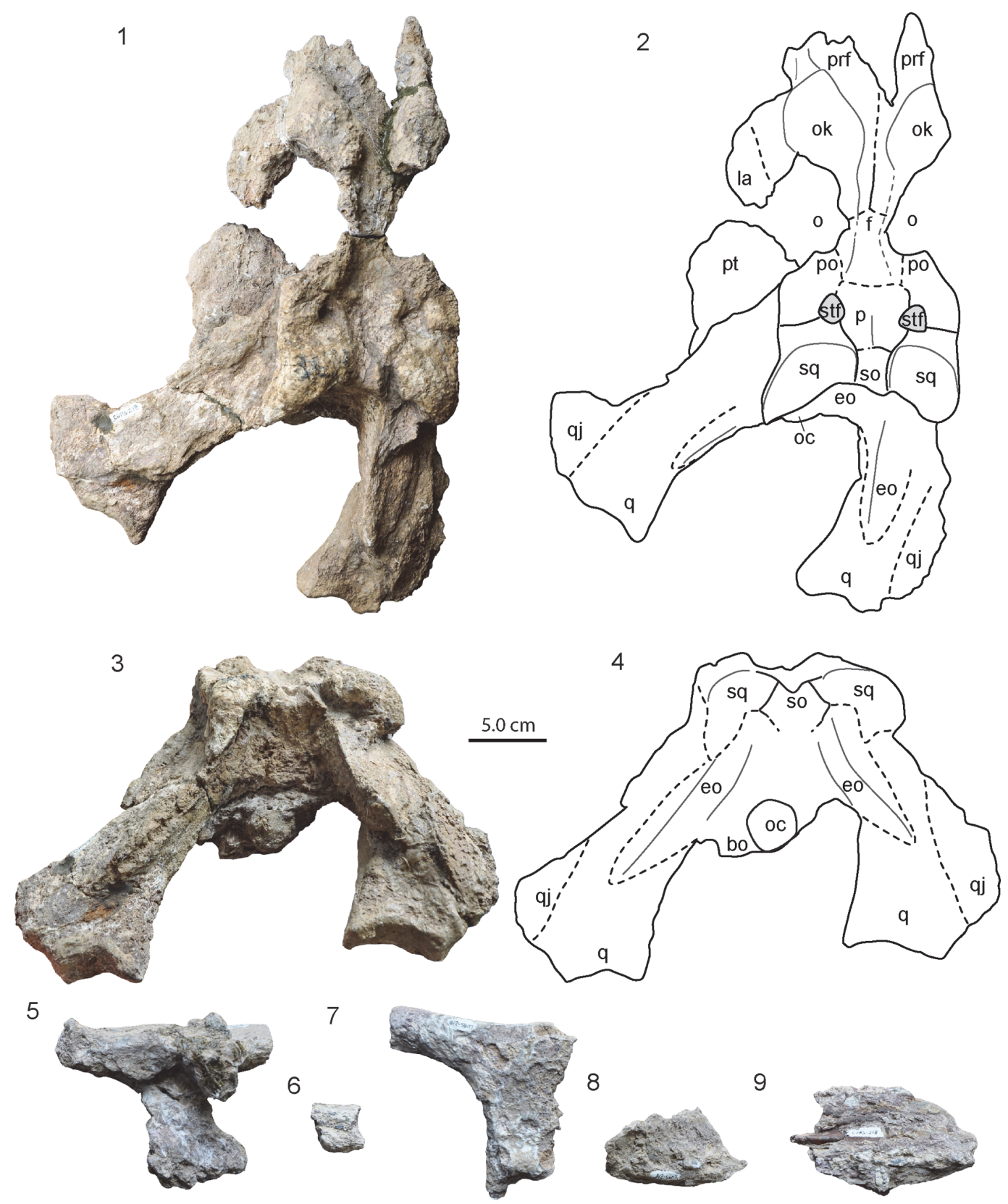

FIGURE 19. Photographs and interpretative drawings of the posterior skull portion and orbitofrontal region as well as additional fragments (possibly jugal and lower jaw fragments) of Mourasuchus arendsi (AMU-CURS-218). 1, 2, skull fragment in dorsal view. Note squamosal eminences and orbital bony excrescences. 3, 4, skull fragment in occipital view. 5-9, skull fragments (partially from jugals?) found associated with the larger skull portions. Abbreviations: bo, basioccipital; eo, exoccipital; f, frontal; j, jugal; la, lacrimal; oc, occipital condyle; o, orbit, ok, orbital knob; $p$, parietal; po, postorbital; prf, prefrontal; pt, pterygoid; q, quadrate; qj, quadratojugal; so, supraoccipital; sq, squamosal; stf, supratemporal fenestra.

suborbital fenestrae and the left and right maxillary portions present 30 and 17 alveoli, respectively. In addition, there is a small maxillary fragment with three alveoli present, but it does not preserve a direct contact with the other parts of the skull.
4) A distorted posterior skull part and associated orbitofrontal region (AMU-CURS-218). Of this specimen, the posterior skull part was originally identified as belonging to Mourasuchus nativus based on: a) prominent squamosal eminences forming a transverse ridge; b) raised skull table with $\mathrm{V}$-shaped out- 
TABLE 1. Comparison of different species of Mourasuchus. Characters 1-8 are taken from the emended diagnosis of M. nativus of Bona et al. (2013a, b); characters 9 and 10 from Bocquentin Villanueva (1984). Data on M. amazonensis is based on holotype DGM 526-R as described and shown by Price (1964) and Langston (1966). Data on M. nativus is based on holotype MLP 73-IV-15-8 and specimen MLP 73-IV-15-9 as shown by Bona et al. (2013a, b), as well as on specimen UFAC- 1424 in Tineo et al. (2015). Data on M. atopus is based on holotype UCMP 38012 in Langston (1965, 1966). Data on M. arendsi is based mainly on holotype UNEFM-CIAAP-1297 as described by Bocquentin Villanueva $(1984)^{1}$, as well as on our revised interpretation of the holotype presented herein ${ }^{2}$. As noted in the discussion, some characters are deemed to be of little taxonomic utility (e.g., characters 9,10$)$ and need to be treated with caution.

\begin{tabular}{|c|c|c|c|c|c|c|c|}
\hline Character & 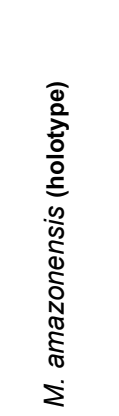 & 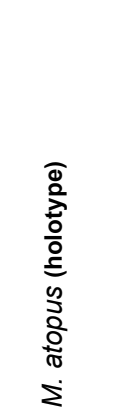 & 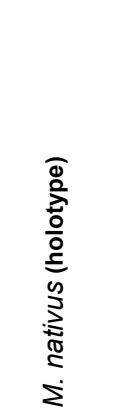 & 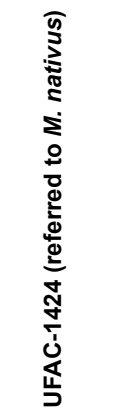 & 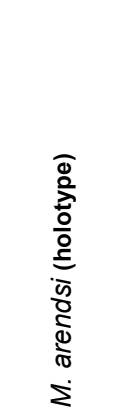 & 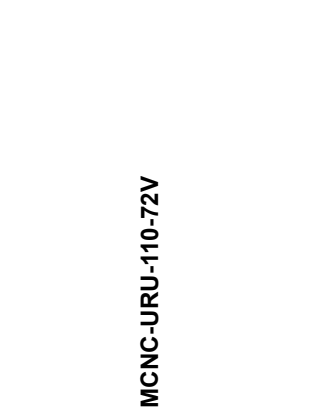 & 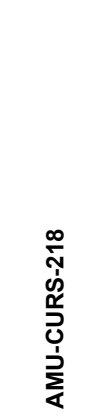 \\
\hline 1. prominent squamosal horns & absent & $?$ & present & present & $\begin{array}{l}\text { absent }{ }^{1} \text {, } \\
\text { present }^{2}\end{array}$ & $?$ & present \\
\hline $\begin{array}{l}\text { 2. marked knobs or bosses at orbital } \\
\text { margin }\end{array}$ & present & present & $?$ & absent & present & present & present \\
\hline $\begin{array}{l}\text { 3. supratemporal fenestra } \\
\text { surrounded rostrally by postorbital } \\
\text { and parietal }\end{array}$ & absent & absent & present & present & present & $?$ & present \\
\hline $\begin{array}{l}\text { 4. dentary linear between } 4 \text { th and } \\
\text { 10th alveoli }\end{array}$ & present & present & $?$ & present & present & present (but obscured) & $?$ \\
\hline $\begin{array}{l}\text { 5. orbits smaller than infratemporal } \\
\text { fenestrae }\end{array}$ & present & present & $?$ & present & present & present & present \\
\hline $\begin{array}{l}\text { 6. middle crest on posterior dorsal } \\
\text { surface of parietal }\end{array}$ & absent & absent & present & present & $\begin{array}{l}\text { absent }^{1} \\
\text { present }^{2}\end{array}$ & $?$ & present \\
\hline $\begin{array}{l}\text { 7. pronounced notch at lateral edge } \\
\text { of jugals }\end{array}$ & present & absent & $?$ & present & $\begin{array}{l}\text { absent }{ }^{1} \text {, } \\
\text { present }^{2}\end{array}$ & present & $?$ \\
\hline $\begin{array}{l}\text { 8. lateral border of maxillae extend } \\
\text { parallel to each other }\end{array}$ & absent & present & $?$ & absent & absent & absent & $?$ \\
\hline 9. premaxillary perforations & $\begin{array}{c}2 \\
\left(1^{\text {st }} \text { and }\right. \\
\left.4^{\text {th }}\right)\end{array}$ & $\begin{array}{c}2 \\
\left(1^{\text {st }} \text { and }\right. \\
\left.4^{\text {th }}\right)\end{array}$ & $?$ & $4 ?$ & $\begin{array}{c}4 \\
\left(1^{\text {st }}-4^{\text {th }}\right)\end{array}$ & $\begin{array}{l}\text { right: } 3\left(1^{\text {st_-3rd }}\right) \\
\text { left: } 3\left(2^{\text {nd }}-4^{\text {th }}\right)\end{array}$ & $?$ \\
\hline 10. palatine constriction & weak? & strong & $?$ & weak & weak $^{1}$ & weak? (area damaged) & $?$ \\
\hline
\end{tabular}

line in occipital view; and c) a midline crest in the posterior part of parietal (Scheyer et al., 2013). The posterior portion was recently complemented with another skull fragment, which had been stored previously in a separate storage section of the collections. This second part preserves mainly the frontal and prefrontal region of the skull (Figure 19). In combination these fossils indicate that this individual of Mourasuchus had both bony knobs at the orbits and strong squamosal eminences.

\section{Mourasuchus spp. Price, 1964}

In addition to the holotype and additional specimens mentioned above, several other, new specimens from the Urumaco Formation assignable to Mourasuchus were recovered in the field over the past years. These materials are presented below and a comparison of the most important specimens of the described Mourasuchus spp. is given in Table 1.

1) Incomplete skull and lower jaw material (Figure 20), associated with few postcranial remains including 10 isolated short vertebrae and three keeled osteoderms (both indicative of Mourasuchus in the fauna), a proximal fragment of a rib and one conical slightly curved and broken tooth of $7 \mathrm{~cm}$ in length (AMU-CURS-073). The very slender jaw and the 


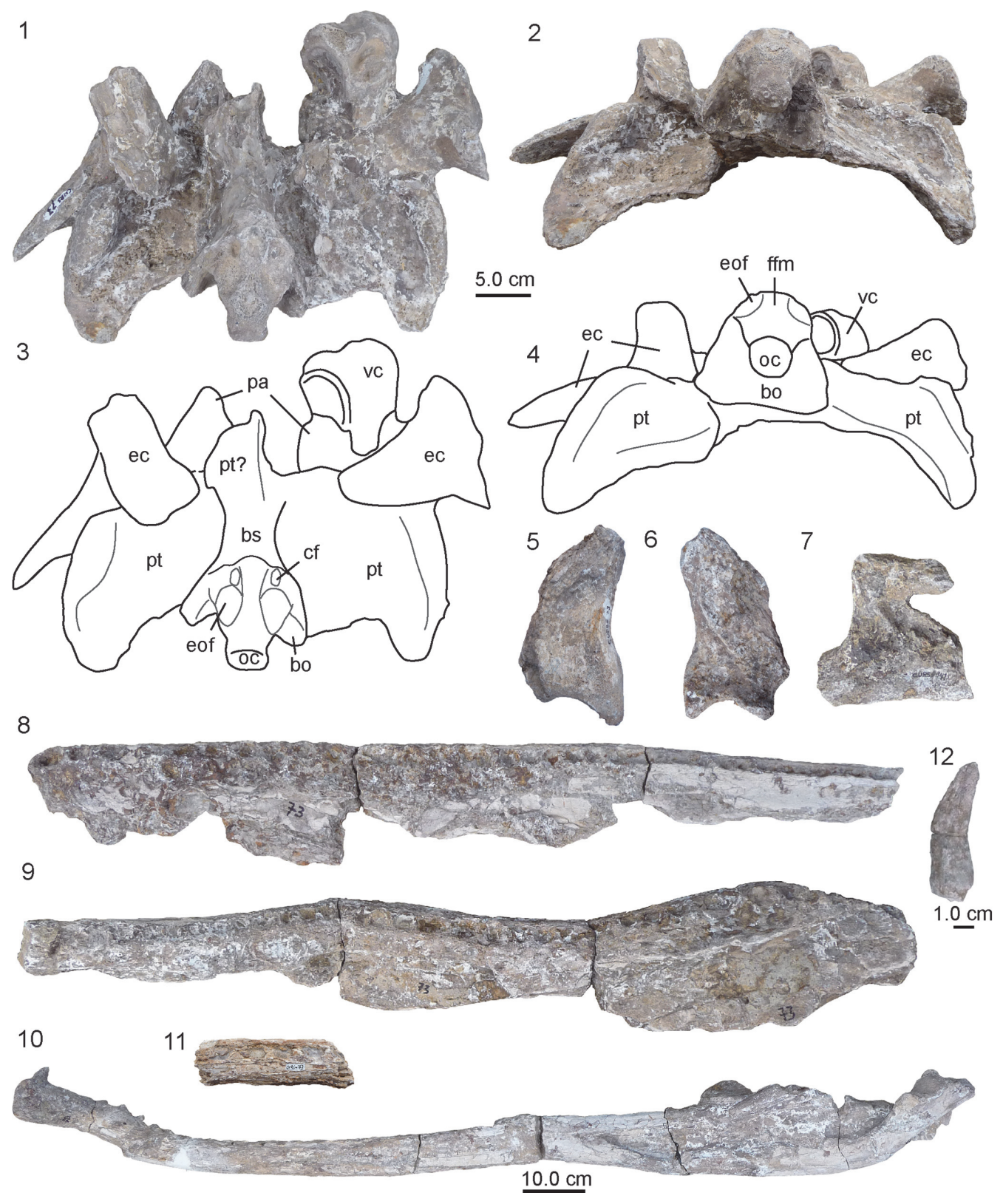

FIGURE 20. Photographs $(1,2,5-12)$ and interpretative drawings $(3,4)$ of skull and lower jaw remains (AMU-CURS073) of Mourasuchus sp. 1, 2, images of the largest fragment of the skull including the basioccipital-basisphenoidpterygoid complex in dorsal (1) and occipital (2) view. 3, 4, interpretative drawings of the skull bones shown in 1 and 2. 5, 6, left quadrate in dorsal (5) and ventral (6) view. 7, fragment tentatively assigned to the postorbital bar of a right jugal in dorsal (?) view. 8, 9, large fragments of the maxillae in ventral view. 10, right lower jaw ramus in medial view. 11, small fragment of the left lower jaw ramus in dorsal view. 12, conical, slightly curved isolated tooth (the tip is set off by a break). Note different scale bar in 10 and 12. Abbreviations: bo, basioccipital; bs, basisphenoid; cf, carotid foramen; ec, ectopterygoid; eof, facet for exoccipital on basioccipital; ffm, floor of foramen magnum on basioccipital; oc, occipital condyle; pa, palatine; pt, pterygoid; vc, vertebral centra.

straight maxillae carrying more than 30 alveoli of overall uniform size, together with the postcrania, allow assignment of the specimen to Mourasuchus. In addition, there are a few more small bone fragments accessioned under the same number, which could not be identified (not shown in the figure). The skull remains include a large fragment with the basioccipital-basisphenoid-pterygoid complex to which parts of the palatines, the two ectopterygoids and a vertebral centrum are still attached (Figure 20.1-4), a left quadrate, a part of a right jugal and two large maxillary fragments (Figure 20.5-9), as 


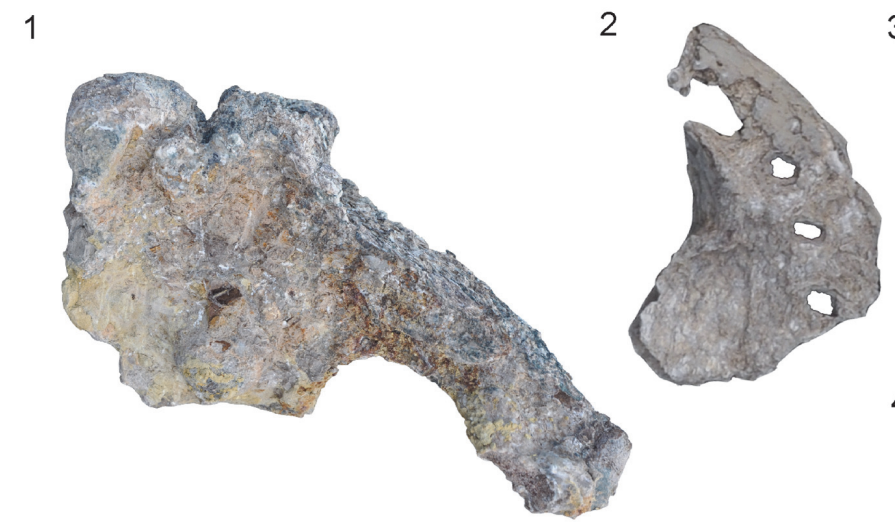

3

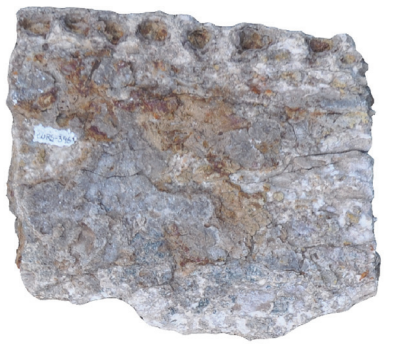

4

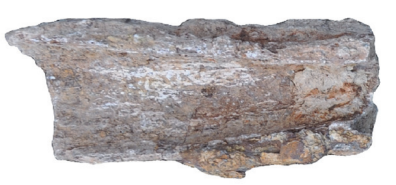

6

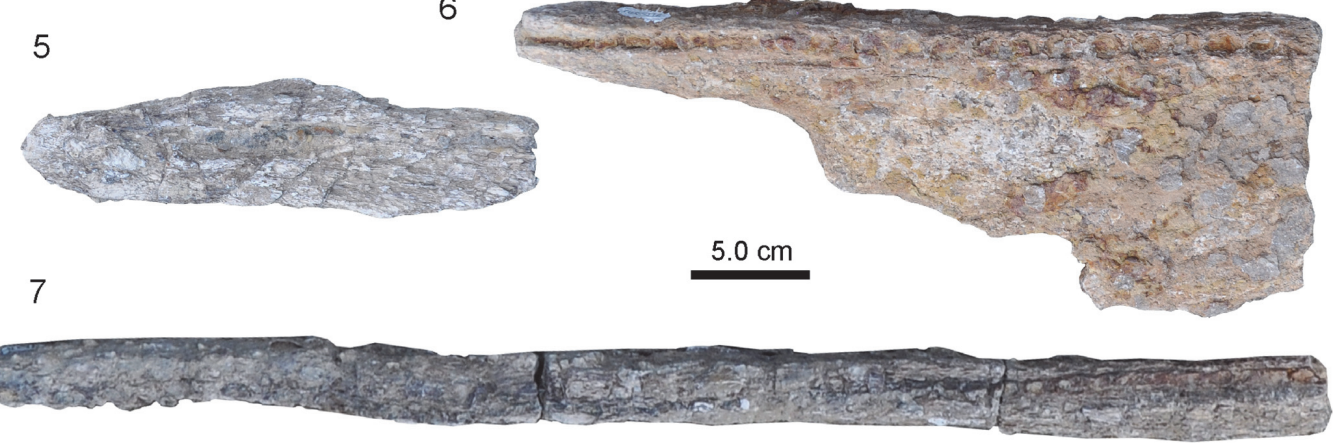

FIGURE 21. Photographs of weathered skull and lower jaw remains (AMU-CURS-396) of Mourasuchus sp. 1, posterior portion of skull and braincase in occipital view. Note squamosal eminences. 2, right premaxilla in dorsal view with perforations for anterior-most teeth of lower jaw. 3, fragment of maxilla with seven alveoli in ventral view. 4, portion of dentary in medial view. 5, unidentified bone fragment. 6, fragment of maxilla with about 26 alveoli in ventral view. $\mathbf{7}$, straight portion of lower jaw in dorsal view. The exact number of alveoli could not be elucidated.

well as a part of the left ramus and mostly complete right ramus of the lower jaw, and an isolated broken, conical tooth (Figure 20.10-12). The articular facets for the exoccipitals are visible on the dorsolateral sides of the occipital condyle. The basioccipital tubera expand ventrally to the condyle. There is only little dorsoventral compaction of the pterygoids in the specimen. The two maxillary fragments derive from the right and left side of the skull. Each bone is broken into three separate pieces - showing 28 and 36 alveoli, respectively (too many if they would derive from only one side). Because both fragments show mostly a straight border, similar sized alveoli for teeth, and no sutural contacts, it cannot be elucidated with confidence which fragment derives from the right and which from the left side of the skull. The part of the left ramus is circular in cross-section and preserves four and a half alveoli. The right ramus of the lower jaw is broken into four pieces which were glued back together, but is otherwise almost complete with only part of the surangular and the coronoid missing. The ramus is $137 \mathrm{~cm}$ in total length and has at least 40 alveoli in the dentary; an exact number cannot be given due to preservational reasons. Based on the lower jaw length and propor- tions of the occipital-pterygoid complex, AMUCURS-073 is comparable in size to Mourasuchus specimen MCNC-URU-110-72V.

2) Seven cranial fragments (Figure 21) of Mourasuchus sp. (AMU-CURS-396; associated with four vertebrae not shown in the figure) including a posterior skull table with right quadrate/quadratojugal and the occipital condyle preserved, two wide maxillary fragments (with seven and ca. 26 alveoli, respectively), one left premaxillary fragment comprising four perforations for lower jaw teeth, a long and straight lower jaw fragment, one fragment belonging to the lower jaw (dentary fragment), as well as an elongated unidentified fragment. The skull fragment shows prominent squamosal eminences framing a deeply incised valley, typically found in some Mourasuchus species (see Table 1). The supraoccipital appears to be displaced somewhat posteriorly between the squamosals. The state of preservation does not allow for identifying further anatomical details. The dentary fragment housing the Meckelian canal is curved.

3) A posterior skull fragment (AMU-CURS-530) with pronounced squamosal eminences heavily 


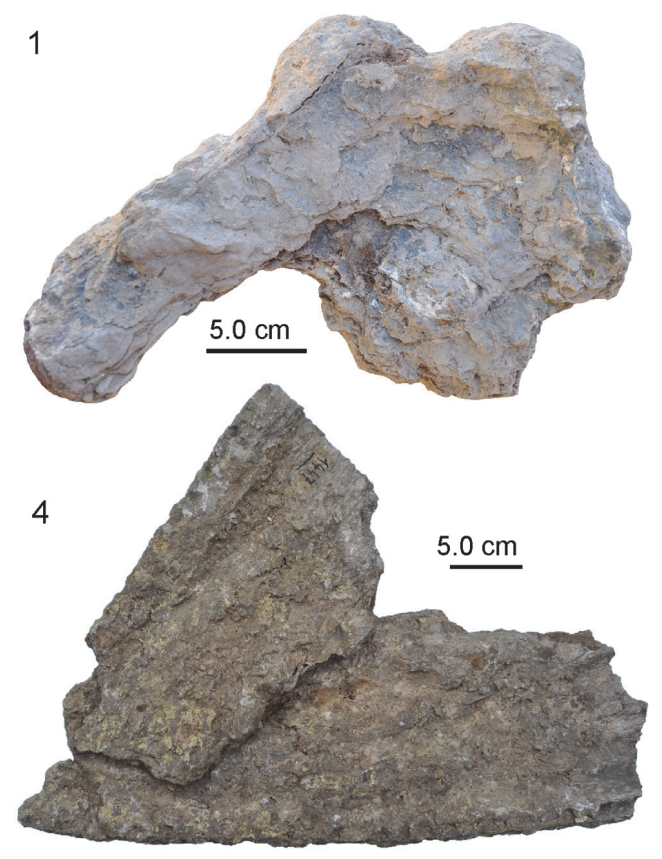

2
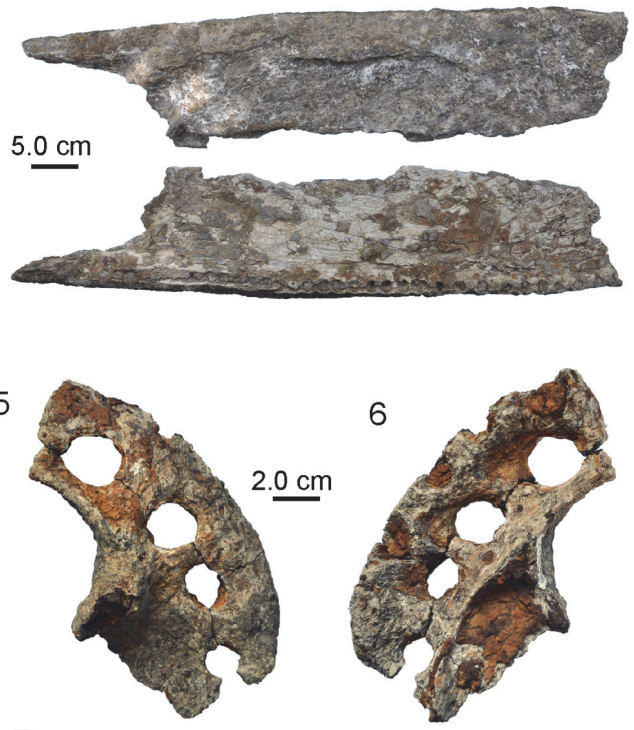

7

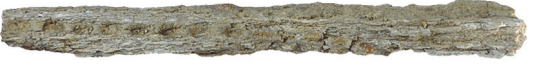

$2.0 \underline{\mathrm{cm}}$
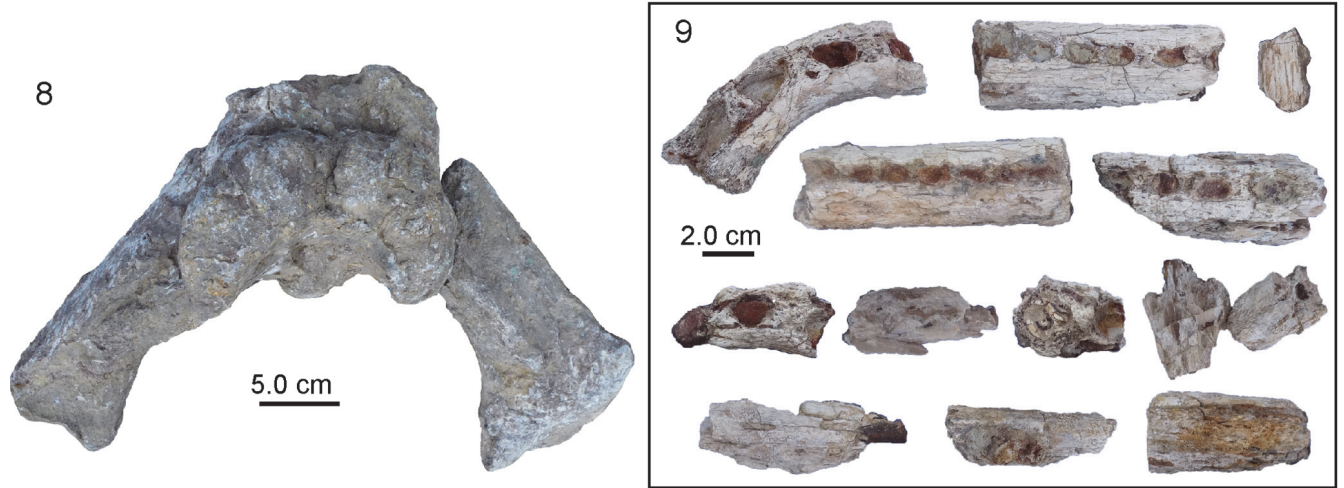

FIGURE 22. Photographs of skull and lower jaw remains of several individuals of Mourasuchus sp. 1, heavily encrusted posterior portion of skull (AMU-CURS-530) in occipital view. Note squamosal eminences. 2, 3, maxillary fragment (UNEFM-CIAPP-1378) in dorsal (2) and ventral (3) view. 4, two maxillary fragments (UNEFM-CIAPP-1447) preserved in overlapping position in ventral view. 5, 6, right premaxilla (AMU-CURS-395) in dorsal (5) and ventral (6) view. 7, small fragment of lower jaw in dorsal view with 13 alveoli (AMU-CURS-537). 8, posterior portion of skull (AMU-CURS-695) in dorsal view. Note massive squamosal eminences. 9, twelve fragments of a lower jaw (AMUCURS-430), with at least the larger fragments belonging to the right ramus. The largest pieces are in dorsal view, showing alveoli.

encrusted with - and locally substituted by - gypsum (Figure 22.1).

4) One maxillary fragment with 38 alveoli (UNEFMCIAAP-1378). The alveoli in the specimen form a very gently curving (convex) tooth row (Figure 22.2$3)$.

5) Two flat and wide, heavily encrusted, maxillary fragments (UNEFM-CIAAP-1447) carrying 11 and 25 alveoli, respectively (Figure 22.4). The alveoli in the larger of the two fragments form a very gently curving (convex) tooth row as well.

6) An isolated right premaxillary fragment (AMUCURS-395) comprising four holes for lower jaw teeth and part of the rim of the external naris (Figure 22.5-6).

7) A slender fragmentary straight part of a small lower jaw showing 13 alveoli (Figure 22.7), belonging to a small specimen of Mourasuchus (AMU-CURS-537).

8) Posterior portion of skull (Figure 22.8) with strong squamosal eminences (AMU-CURS-695) from Tío Gregorio locality in the Urumaco Formation.

9) Twelve isolated fragments (Figure 22.9) of a lower jaw (AMU-CURS-430).

10) Associated lower jaw fragments and isolated left prefrontal of Mourasuchus sp. (AMU-CURS-748; 

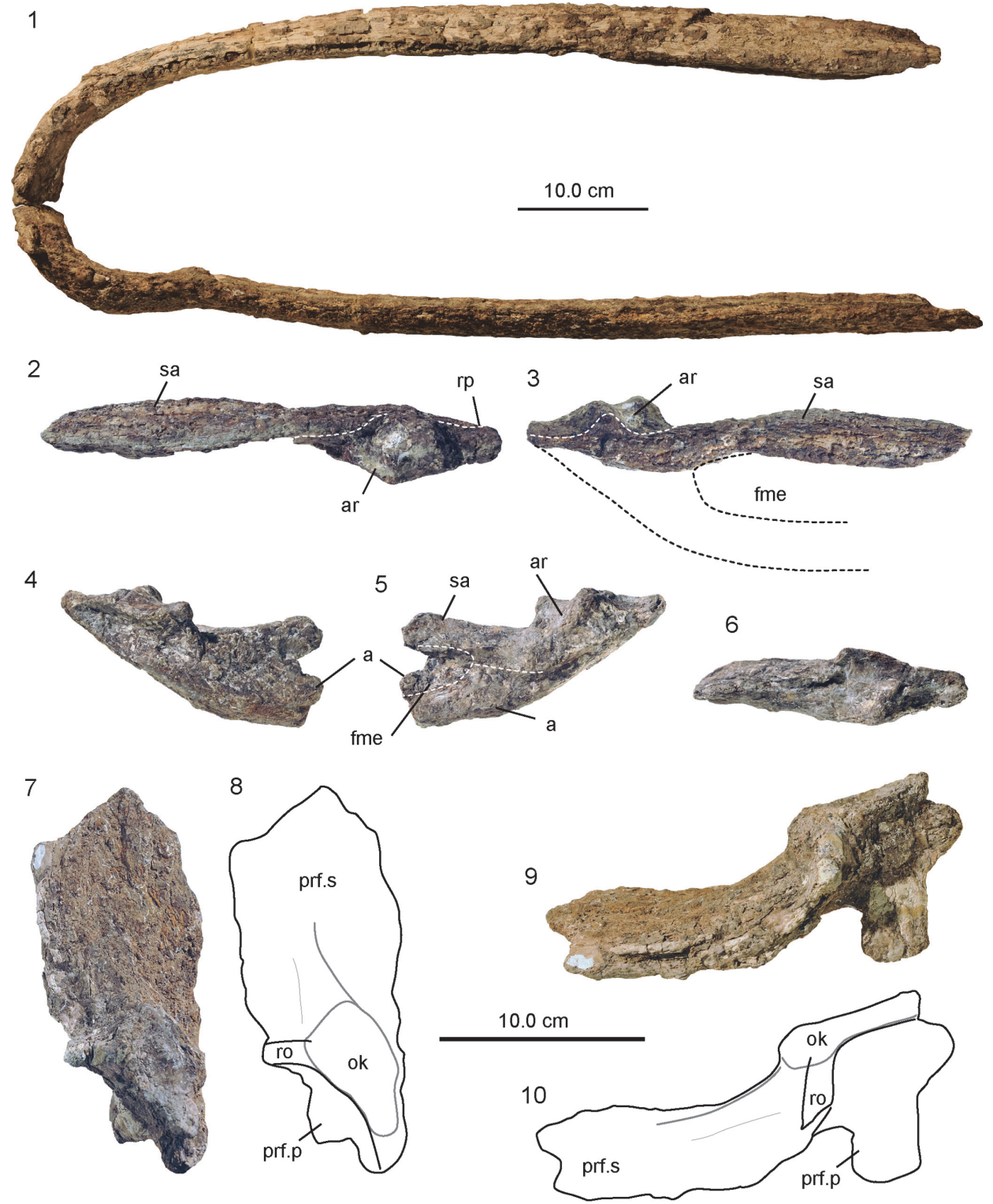

FIGURE 23. Photographs of lower jaw remains and associated left prefrontal of Mourasuchus sp. (AMU-CURS-748). 1 , anterior and medial portion of lower jaw in dorsal view. Note lateromedial distortion of the right ramus and the break in the anterior portion of the left ramus. 2-6, posterior portions of the lower jaw in dorsal $(2,6)$, lateral $(\mathbf{3}, \mathbf{5})$, and medial (4) view. 7-10, images and schematic interpretations of prefrontal in dorsal $(\mathbf{7}, \mathbf{8})$ and lateral $(\mathbf{9}, \mathbf{1 0})$ view. Abbreviations: a, angular; ar, articular; fme, external mandibular fenestra; ok, ornamental knob; prf.p, prefrontal pillar; prf.s, prefrontal shelf; ro, rim of orbit; rp, retroarticular process; sa, surangular.

Figure 23). The first 30 alveoli of the right ramus of the lower jaw are discrete, followed by 12 alveoli which are less distinguishable and often appear confluent with adjacent alveoli (the number would correspond with the 42 plaster-cast teeth on the right lower jaw ramus of MCNC-URU-110-72V). On the left ramus, only the anterior-most 10 alveoli are distinguishable. In both rami the four anterior-most alveoli are the largest, which corresponds with the four perforations seen in the premaxillae of other Mourasuchus specimens from Urumaco. The posterior parts of both rami have been separated from the anterior portions and there is a gap in between the bones. The left part preserves the angular and surangular up to the posterior portion of the external mandibular fenestra, as well as the articular. The right part preserves the articular and a large portion of the surangular, whereas the angular is largely missing. This part, together with the anterior portion of the right ramus experienced some distortion. The splenial is missing in both rami, but according to the attachment scar on the dentary it would have reached the thirteenth alveolus from anterior (tenth alveolus in M. atopus according to Langston, 1965). 
The anterior portions of the rami are 71 (right) and $74 \mathrm{~cm}$ (left) in length, the posterior ones $35 \mathrm{~cm}$ (right) and $21.5 \mathrm{~cm}$ (left) respectively. Total length of the lower jaw might have been similar or slightly smaller than specimen AMU-CURS-073. The isolated left prefrontal (Figure 23.7-10) has a length of $21 \mathrm{~cm}$ and a maximum width of $9 \mathrm{~cm}$. It shows a long medial articulation with the right prefrontal of about $14 \mathrm{~cm}$ in length. The large but strongly eroded and anteromedially situated bony knobs in front of the orbits continue into a descending ridge onto the prefrontal shelf. The sutural contacts with the nasal, frontal, and the lacrimal are not well traceable due to the poor preservation of the specimen. A stout descending process is preserved ventrally, below the medial portion of the orbital rim, which is the dorsal portion of the prefrontal pillar. There are two low ventral keels or laminae protruding from the anterior portion of the prefrontal.

Genus PURUSSAURUS Barbosa-Rodrigues, 1892 Purussaurus mirandai Aguilera, Riff, and Bocquentin Villanueva, 2006

The type species of Purussaurus, P. brasiliensis, was described based on the anterior portion of a right mandibular ramus from the Miocene Solimões Formation, Acre, Brazil (BarbosaRodrigues, 1892). More complete cranial and mandibular material from this formation was later described and figured (Aguilera et al., 2006; Aureliano et al., 2015). Besides P. brasiliensis, two more species were described, $P$. neivensis from the middle Miocene, La Venta fauna, Colombia (Mook, 1941; Langston, 1965) and the Pebas system of Peru (Salas-Gismondi et al., 2015), and P. mirandai from the Urumaco Formation, Venezuela (Aguilera et al., 2006).

To date, only a single species, Purussaurus mirandai, is recognised in the Urumaco Formation (Aguilera et al., 2006; Sánchez-Villagra and Aguilera, 2006; Riff et al., 2010; Scheyer et al., 2013). Besides the cranial and mandibular remains used in the original description (of the holotype UNEFMCIAAP-1369, Figure 24.1-5; paratypes UNEFMCIAAP-1445, Figure 24.6; AMU-CURS-135, Figure 24.7, MCNC-URU-115-72V, Figure 25.1; MCNCURU-157-72V; referred material AMU-CURS-033 and -057; MCNC-URU-76-72V), several other Purussaurus specimens including cranial remains are stored in the collections in Urumaco, Coro, and Caracas or have since been discovered in the field. It is difficult in many cases, however, to identify isolated specimens down to the species level.

MCNC-URU-115-72V constitutes the anterior portion of a right dentary (Figure 25.1). This dentary fragment preserves the anterior nine and a half alveoli, the fourth alveolus being $46 \mathrm{~mm}$ in diameter. It was apparently found close to specimen MCNC-URU-112-72V, associated cranial and mandibular material that was both heavily and falsely reconstructed with plaster, which, following Aguilera et al. (2006, page 230) is excluded herein.

A right premaxilla and maxilla shown in ventral view, instead of the aforementioned right dentary, was presented by Aguilera et al. (2006) as paratype material (as 'MCC URU-115-72V': Aguilera et al., 2006, figure 3B). These bones are part of a more complete cranial specimen, accompanied by the left premaxilla and maxilla, as was shown previously in Aguilera (2004, page 91). The remains from the left side of the skull could be relocated and have been virtually assembled to their life position in Figure 25.2-3, which is some degrees wider than previously indicated (Aguilera, 2004), forming a round snout shape. The premaxillae are huge, flat, and carry a prominent posterior process framing a huge external narial opening, thus allowing assignment of the material to Purussaurus mirandai. We hypothesise that all skull fragments (Figure 25.2-4) belong to MCNC-URU-158$72 \mathrm{~V}$ (see discussion below), together with more posterior skull parts, including a partial skull table, a jugal, the pterygoids (?), an ectopterygoid, and the quadrates (Figure 25.5-21). On the other hand, it is noteworthy that at least one other, smaller skull fragment (Figure 25.22) assignable to Purussaurus was accessioned under the same number (two small caimanine skulls, not shown in the figures, are also within this assemblage). Furthermore, two lower dentary fragments lacking documentation (Figure 25.23) likely belong to MCNC-URU-158$72 \mathrm{~V}$ as well. The fragments show the symphyseal region, which was measured to be $21 \mathrm{~cm}$ in anteroposterior length. The left dentary has nine alveoli preserved, whereas 17 alveoli are preserved on the right dentary fragment. The diameter of the first alveolus is about $6 \mathrm{~cm}$.

\section{Purussaurus cf. P. mirandai Aguilera, Riff, and Bocquentin Villanueva, 2006}

AMU-CURS-057 was previously listed as a referred specimen of Purussaurus mirandai by Aguilera et al. (2006). These lower jaw remains of a smaller (likely juvenile) individual are here figured for the first time (Figure 26.1). They resemble the lower jaw remains of the $P$. mirandai holotype in shape and proportions. In addition, the dentaries are less deep than those of $P$. amazonensis. In this specimen the anterior parts of the left and right dentaries are preserved, showing 13 alveoli and 14 alveoli, respectively. The presence and shape of 


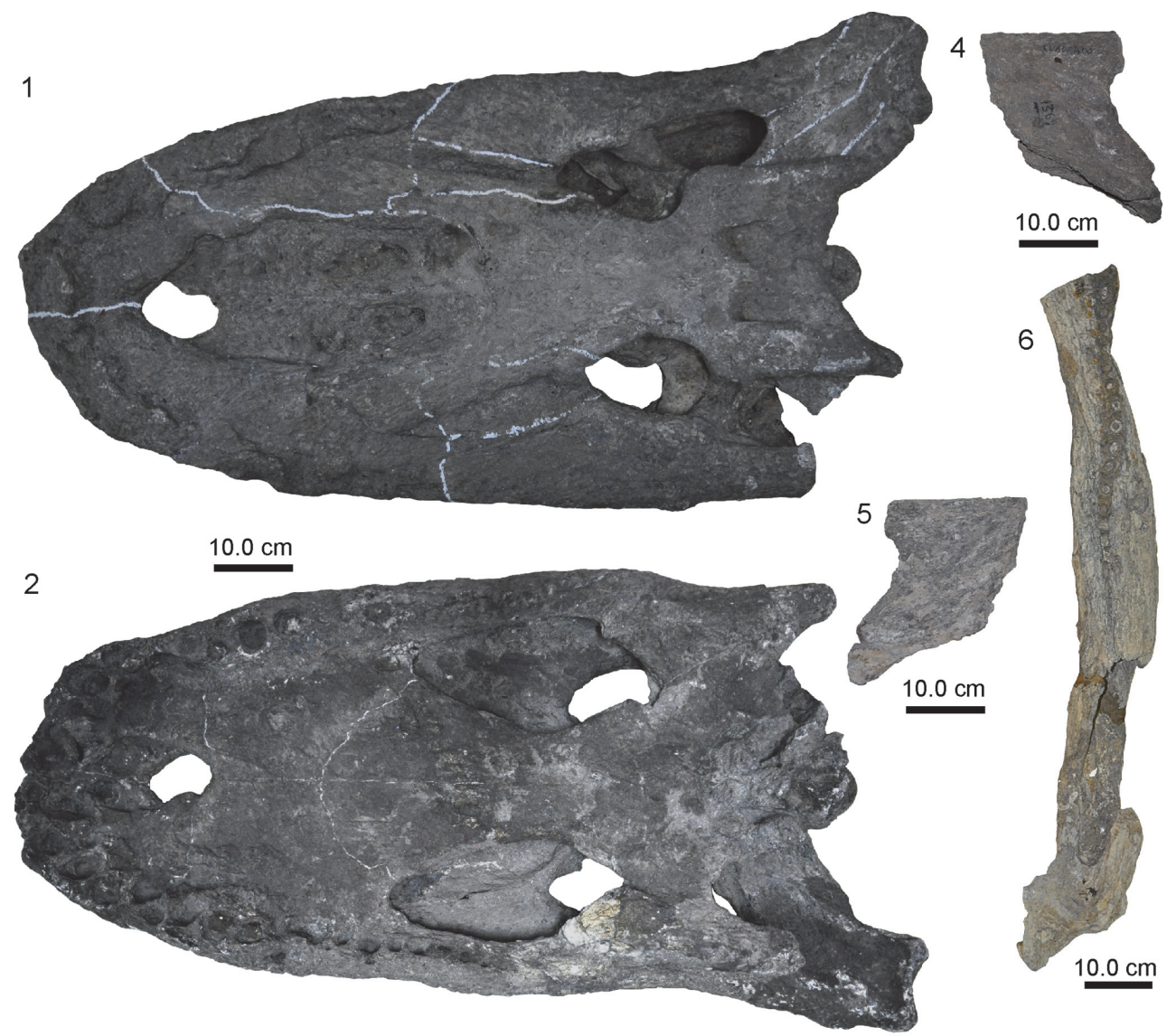

3
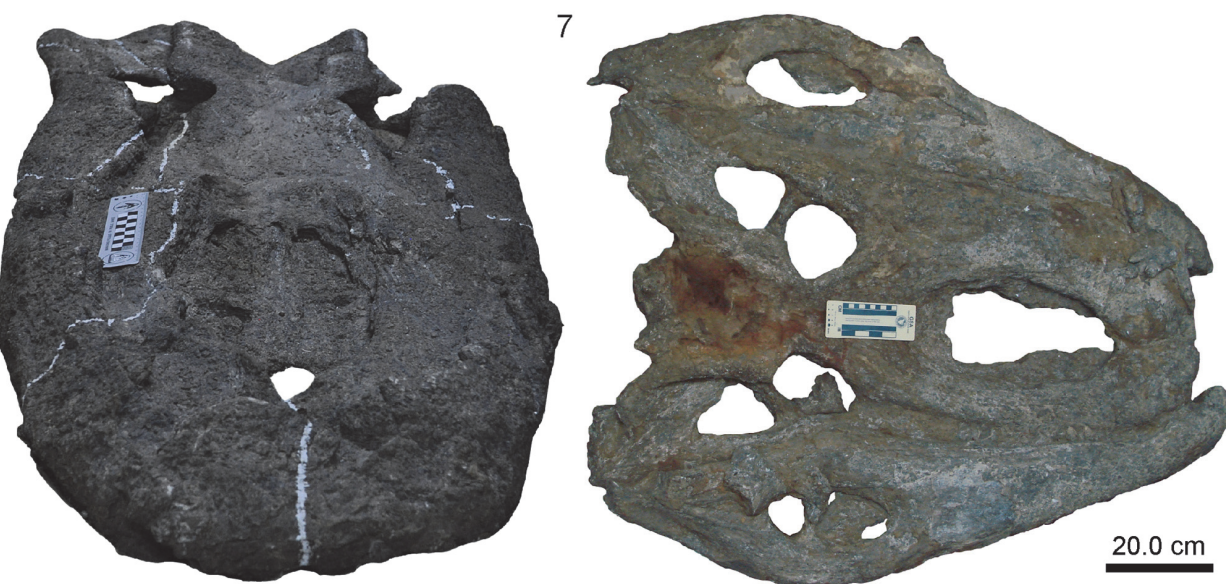

FIGURE 24. Photographs of skull of holotype (1-5: UNEFM-CIAAP-1369; associated lower jaw not shown) and paratypes UNEFM-CIAAP 1445 (6) and AMU-CURS-135 (7) of Purussaurus mirandai. 1-3, holotype skull in dorsal (1), ventral (2) and angled rostral view (3); the latter is not to scale. 4, 5, skull fragment labelled as "quadrate" of UNEFM-CIAAP-1369, which possibly constitutes a proximal fragment of the left quadrate/quadratojugal complex of the holotype skull. 6, right lower jaw in dorsal view. 7, largely unprepared skull and attached left and right lower jaw rami in dorsal view (picture courtesy: Jorge Moreno, Colombia).

splenials is not clear because of preservational reasons. Compared to the complete lower jaw of the holotype UNEFM-CIAAP-1369, both fragments represent about one third of the total lower jaw length. Given the fragmentary nature of the specimen, however, we refer to it as Purussaurus cf. P. mirandai herein.

Besides the holotype specimen (UNEFMCIAAP 1369) of Purussaurus mirandai, the UNEFM collections house also two other speci- 

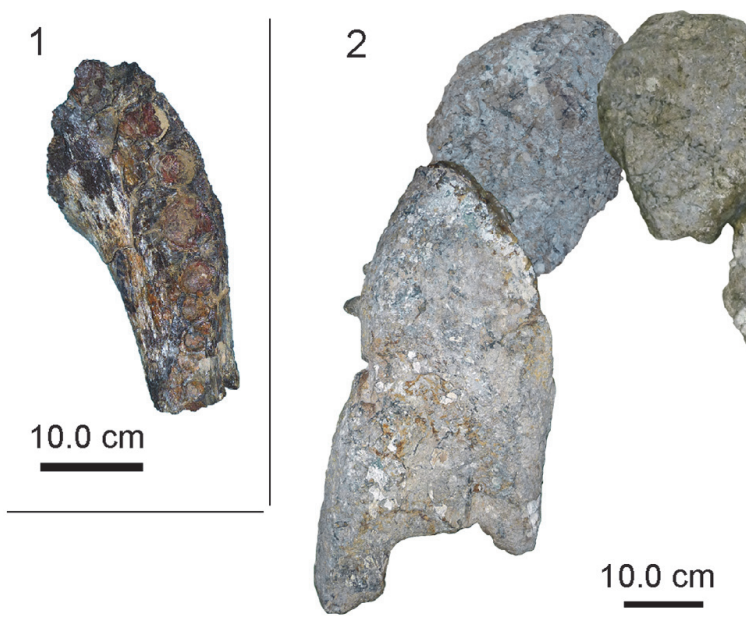

4

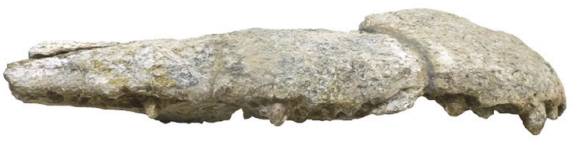

8

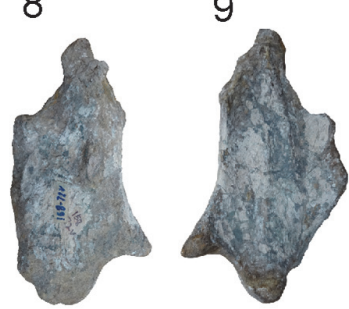

18

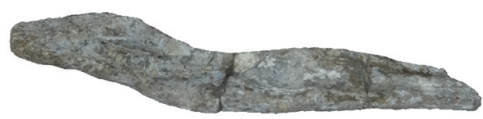

20

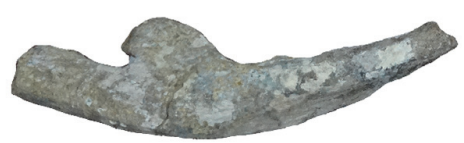

11

10

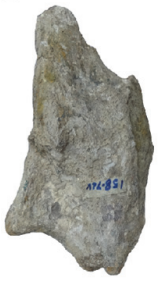

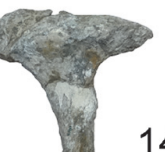

5

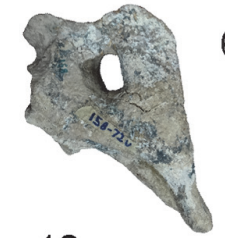

3

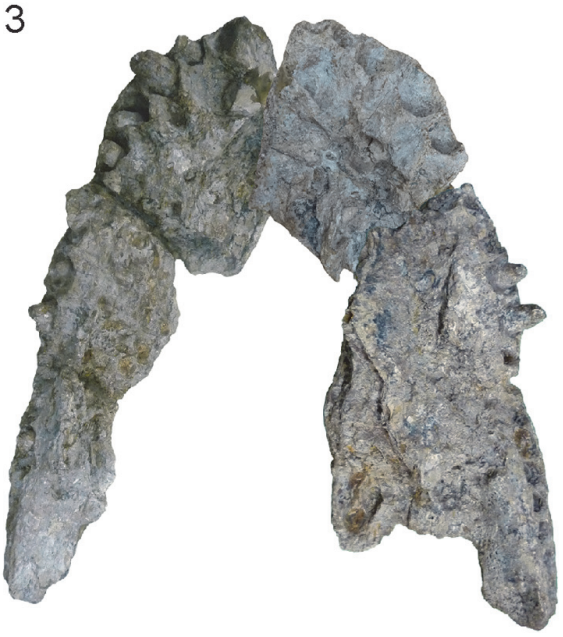

6

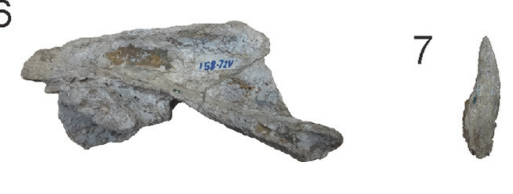

12

13

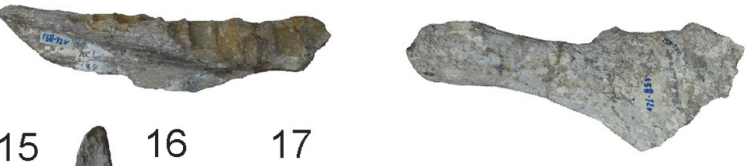

19

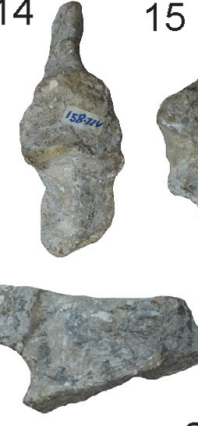

21

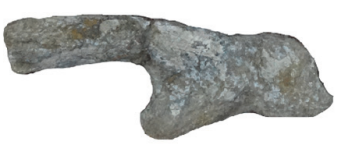

22

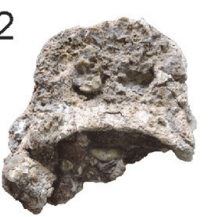

17

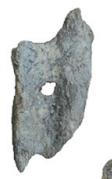

FIGURE 25. Photographs of skull and jaw material of Purussaurus. 1, right dentary fragment (MCNC-URU-115-72V) in dorsal view; 2-23, skull and lower jaw material belonging to several different individuals currently accessioned under a single collection number (MCNC-URU-158-72V). 2-3, anterior part of skull (electronically assembled to represent life position) in dorsal and ventral view. Only the right premaxilla and maxilla (2-4) were shown as part of the paratype series of $P$. mirandai by (Aguilera et al., 2006). 5, right part of skull table in dorsal view. 6, left part of skull table in lateral view. 7, isolated tooth. 8, 9, left quadrate in dorsal and ventral view. 10, right quadrate in dorsal view. 11, right ectopterygoid in posterolateral view. 12, lower jaw fragment in medial view with alveoli. 13, right jugal in lateral view. 14, 15, articulars with retroarticular processes in dorsal view. 16, 17, pterygoids? 18-21, lower jaw elements. 18, possible anterior fragment of left surangular in ventral view? 19, posterior fragment of surangular in lateral view? 20, fragment of right angular in medial view? 21, fragment of right surangular in medial view? 22, smaller skull table in the assemblage also assignable to Purussaurus in dorsal view. 23, anterior portion of lower jaw, initially referred to and figured as MCNC-URU-157-72V by (Aguilera, 2004). 

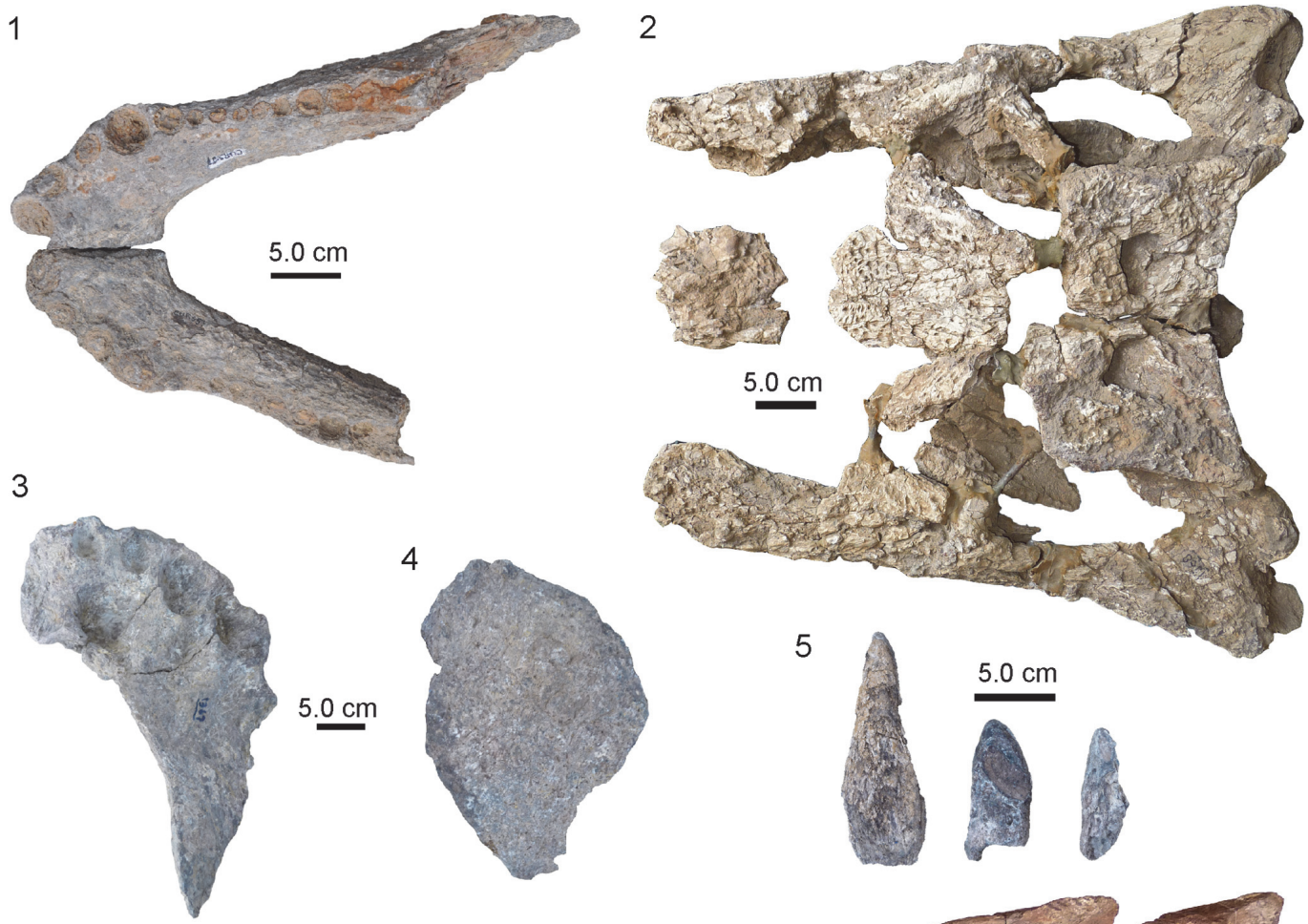

5
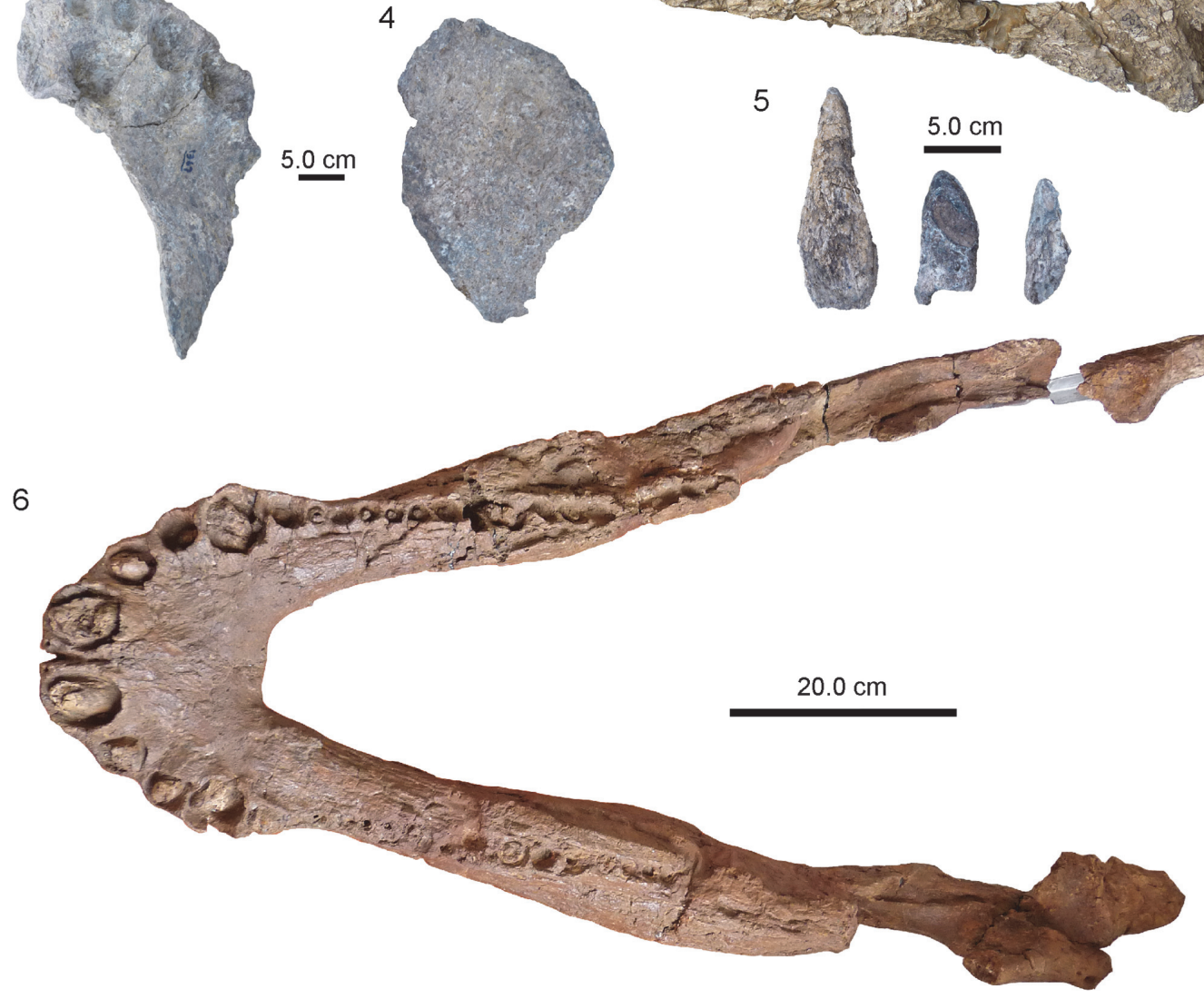

FIGURE 26. Photographs of specimens referable to Purussaurus cf. $P$. mirandai. 1, referred specimen AMU-CURS057, right and left dentaries in dorsal view. 2, posterior skull fragment UNEFM-CIAAP-1368/1372 in dorsal view. 3, 4, premaxillae of UNEFM-CIAAP-1367 in dorsal and ventral view. 5, three isolated teeth of UNEFM-CIAAP-1367. 6, lower jaw of AMU-CURS-541 in dorsal view.

mens assignable to Purussaurus cf. P. mirandai. These include a smaller, badly weathered posterior skull fragment (Figure 26.2; UNEFM-CIAAP 1368/ 1372 , stored at the museum in Coro), as well as a specimen which consists of numerous associated cranial and postcranial bones (UNEFM-CIAAP 1367, stored at the collections at Taratara near Coro) of which we present here only the left and right premaxillae (which are low in height and frame a large external narial opening) and three isolated teeth of various height (Figure 26.3-5). The dorsal, medial, and lateral borders of the left premaxilla are only partially preserved, with the bone showing only four and a half alveoli, and it misses the dorsal posterior process completely. Ventrally, a portion of the secondary palate of the maxilla appears to be still attached to the premaxilla. The right premaxilla appears more complete 

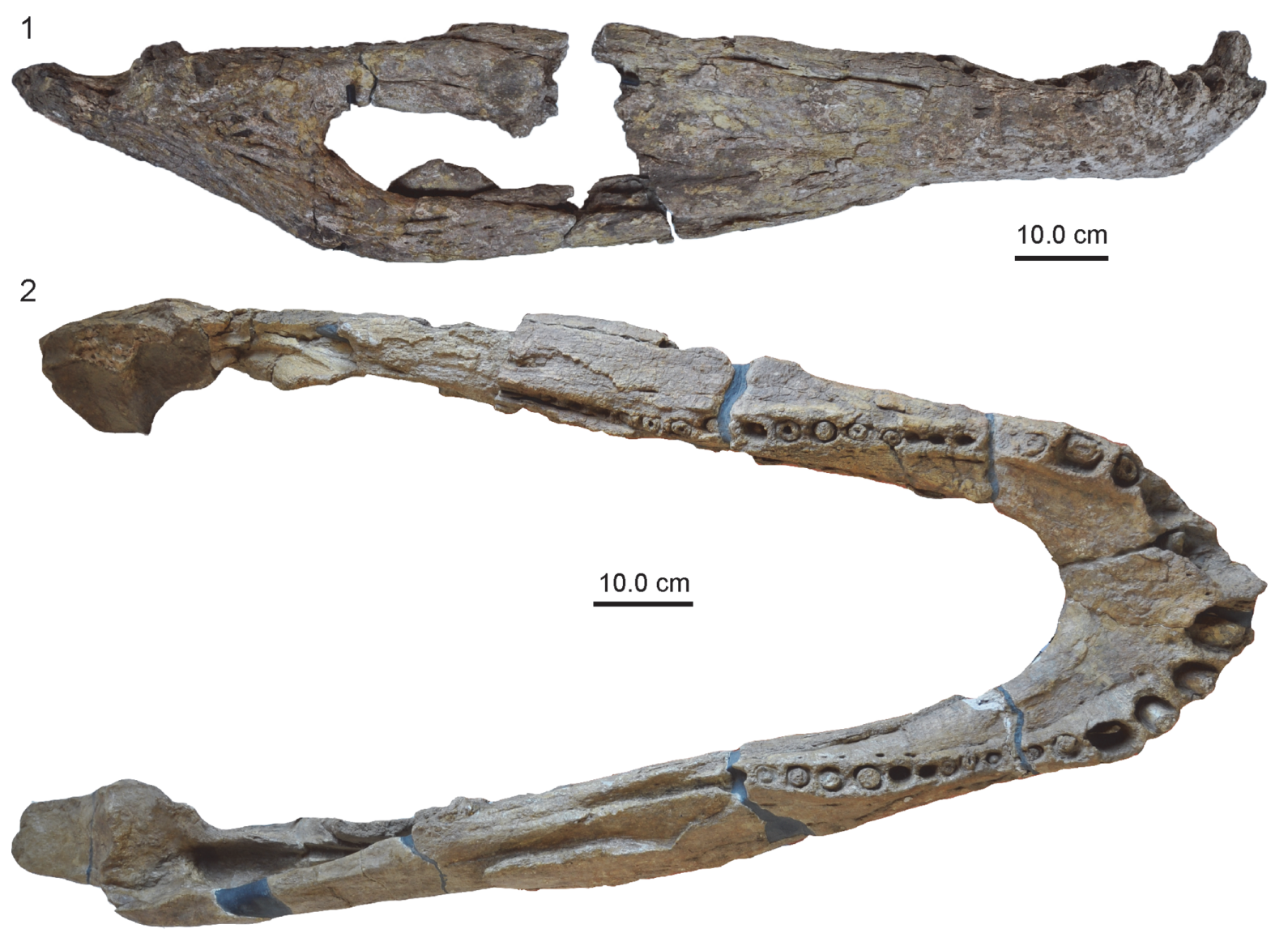

FIGURE 27. Photographs of lower jaw material of Purussaurus cf. P. mirandai in the show room of Museo Paleontológico Urumaco. 1, right mandibular ramus in lateral view (AMU-CURS-685). 2, lower jaw in dorsal view (MCNUSB no number).

dorsally and laterally, but it also shows only four and a half alveoli ventrally, and it lacks the dorsal tip of the posterior process.

Although it lacks the anterior snout portion and thus the characteristic narial opening, UNEFMCIAAP 1368/1372 has a rather low skull height as is typical for Purussaurus mirandai. The specimen further shows a triangular skull shape with a squared skull table and a posterior gently concave margin, as well as small supratemporal fenestrae. Due to poor preservation sutures are not well traceable (with the exception of the right quadratequadratojugal suture). The posterior skull fragment is accompanied by a smaller bone fragment of unclear position on the anterior part of the rostrum. There is also a collection of seven isolated teeth accessioned under UNEFM-CIAAP 1368 (stored at Taratara near Coro), which are recurved and much too large (up to $10 \mathrm{~cm}$ in length) to belong to the posterior skull fragment curated in the same institu- tion. These teeth rather belong to a giant gavialid, such as Gryposuchus.

In addition, a new associated large specimen, AMU-CURS-541 (Figure 26.6), was recovered from the 'North of El Picache' locality in November 2013, which included most of the lower jaw and some skull fragments besides numerous postcranial elements. The lower jaw is rather low and virtually identical in shape and proportions to that of the Purussaurus mirandai holotype. As this specimen is currently under study together with the associated postcranium elsewhere, we refrain from adding to its morphological description here.

Two specimens (Figure 27) are stored in the show rooms of the Museo Paleontológico Urumaco, namely a right mandibular ramus (AMUCURS-685), and a well-preserved, articulated lower jaw, which lacks part of the left dentary tip, the left surangular and the retroarticular process (MCN-USB no number). AMU-CURS-685 measures $133 \mathrm{~cm}$ in length the maximum height is 24 


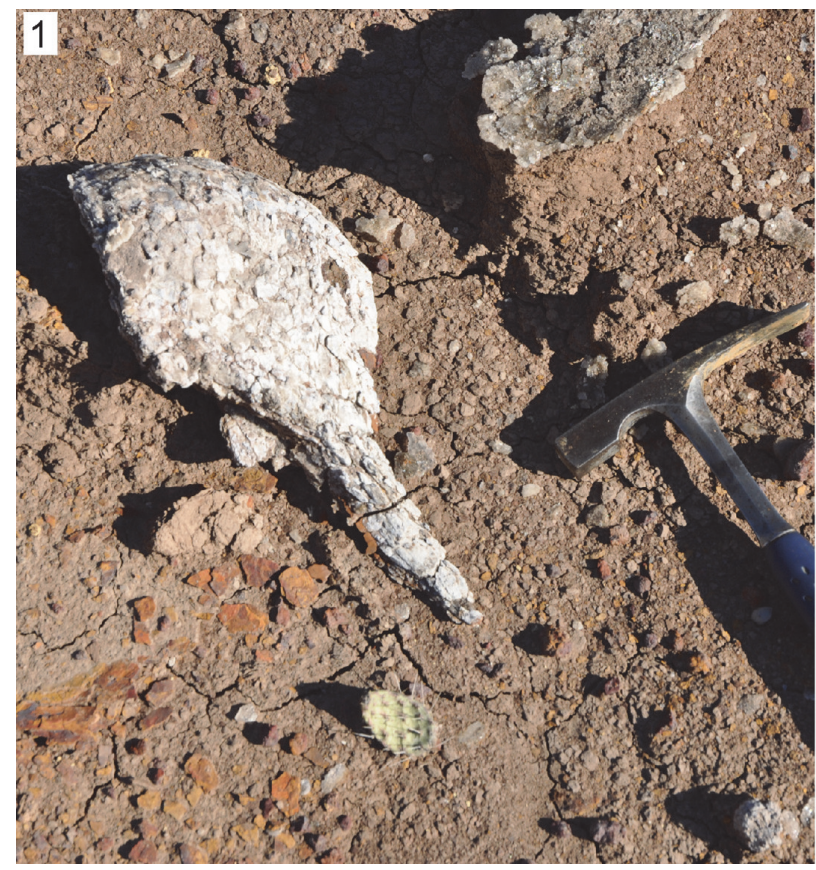

2

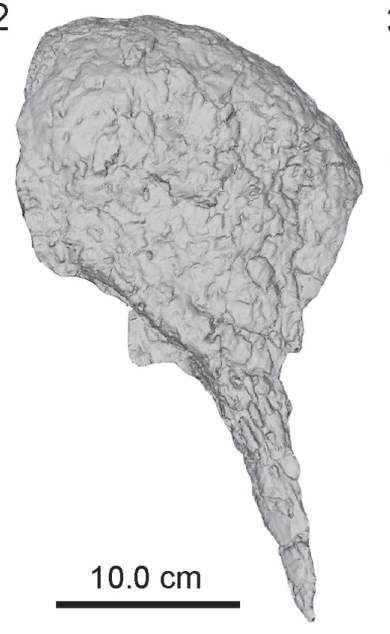

4

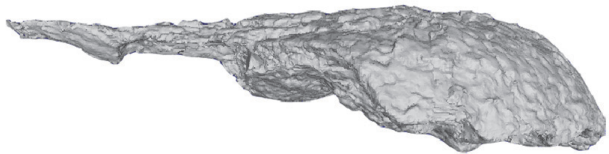

FIGURE 28. Photographs of isolated right premaxilla of Purussaurus cf. $P$. mirandai (AMU-CURS-602). 1, specimen prior to collection in the field (dorsal view). 2-4, surface scan model of specimen (taken with an Artec Spider Surface Scanner) in (2) dorsal, (3) ventral, and (4) lateral view.

$\mathrm{cm}$. The retroarticular process has a length of 14 $\mathrm{cm}$ from the posterior tip to the articular facet. MCN-USB no number shows 21 alveoli in both rami, despite the bad preservation of the right ramus, whose length is $130 \mathrm{~cm}$; the length of the symphysis measures $17 \mathrm{~cm}$. The splenials reach anteriorly up to the eighth alveolus. Although both jaws are congruent with the morphology described for the lower jaw of the holotype of Purussaurus mirandai (Aguilera et al., 2006), them being isolated findings, we refer them to Purussaurus cf. $P$. mirandai instead.

An isolated right premaxilla with most of its posterior process intact (AMU-CURS-602; Figure 28) and disarticulated skull remains found associated with some postcranial elements of a single specimen (AMU-CURS-528; Figure 29), all assignable to Purussaurus cf. P. mirandai, were recovered in November 2013 from the Upper Member of the Urumaco Formation, in the 'North of El Picache' and 'Northeast San Rafael' localities, respectively. The premaxilla AMU-CURS-602 has a maximum length of $35.5 \mathrm{~cm}$ and a maximum width of $19.5 \mathrm{~cm}$. AMU-CURS-528 includes the right premaxilla (Figure 29.1-2) with five alveoli, the right jugal (Figure 29.3-4), the left and right ectopterygoids (Figure 29.5-8), a dentary fragment (Figure 29.9-10), and seven isolated teeth (Figure
29.11). The cranial elements were associated with an ischium, possible ilium, rib, and metapodial fragments, currently under study elsewhere). The long posterior premaxillary processes framing a large external nasal aperture together with the restricted thickness (=height) of the premaxillae in AMU-CURS-528 and AMU-CURS-602 argue for an assignment of the material to $P$. mirandai. The premaxilla also preserves a large margin of the incisive foramen, which does not reach in between the first premaxillary alveoli. The dentary fragment preserves the anterior portion of the external mandibular fenestra. In medial view, the scar for the articulation with the splenial is visible ventrally, whereas the dorsal border of the dentary is broken off. The jugal has a deep anterior portion, a strong inset portion of the postorbital pillar, and a slender infratemporal bar.

The ectopterygoids have a triangular articulation with the jugal and maxilla with the anterior process pointing medially, indicating that the ectopterygoid does not extend parallel to the posterior maxillary tooth row. The left ectopterygoid preserves an ectopterygoid-pterygoid flexure, typical of the caimanine crown group (Brochu, 1999). The teeth of AMU-CURS-528 (Figure 29) are more strongly weathered so that their original shape is often obscured and details are no longer visible. 


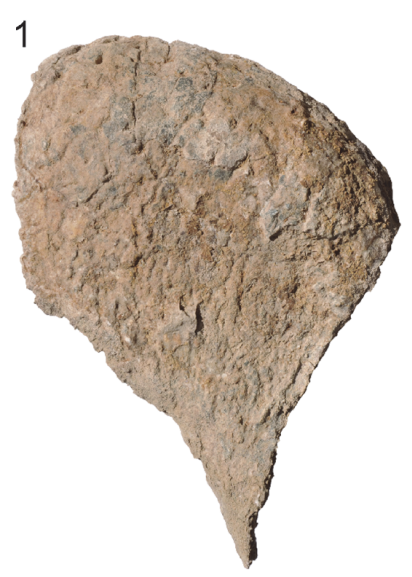

5

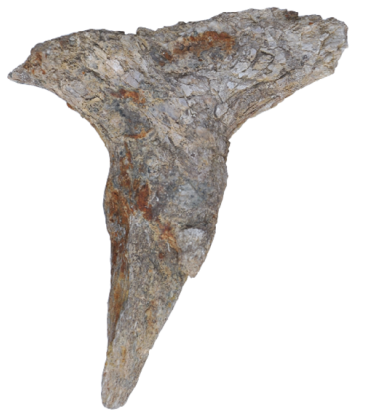

2

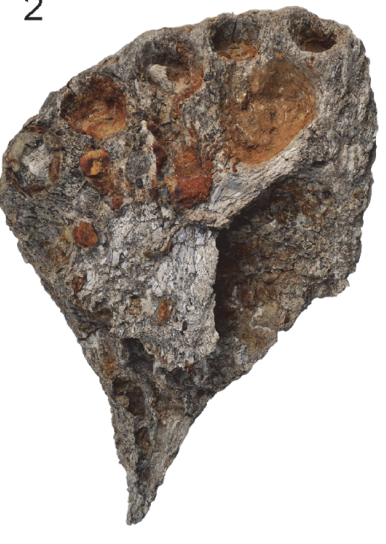

6

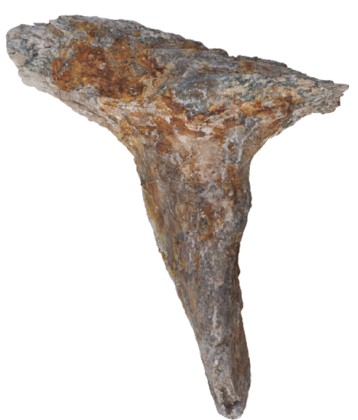

7

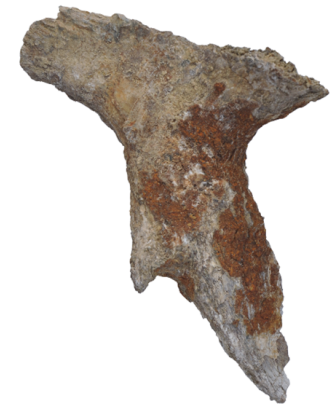

3

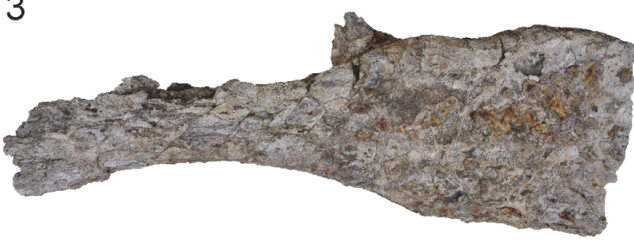

4

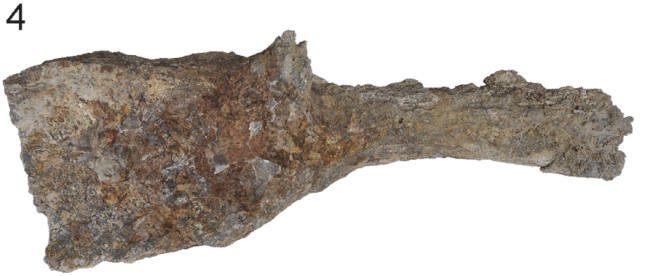

8
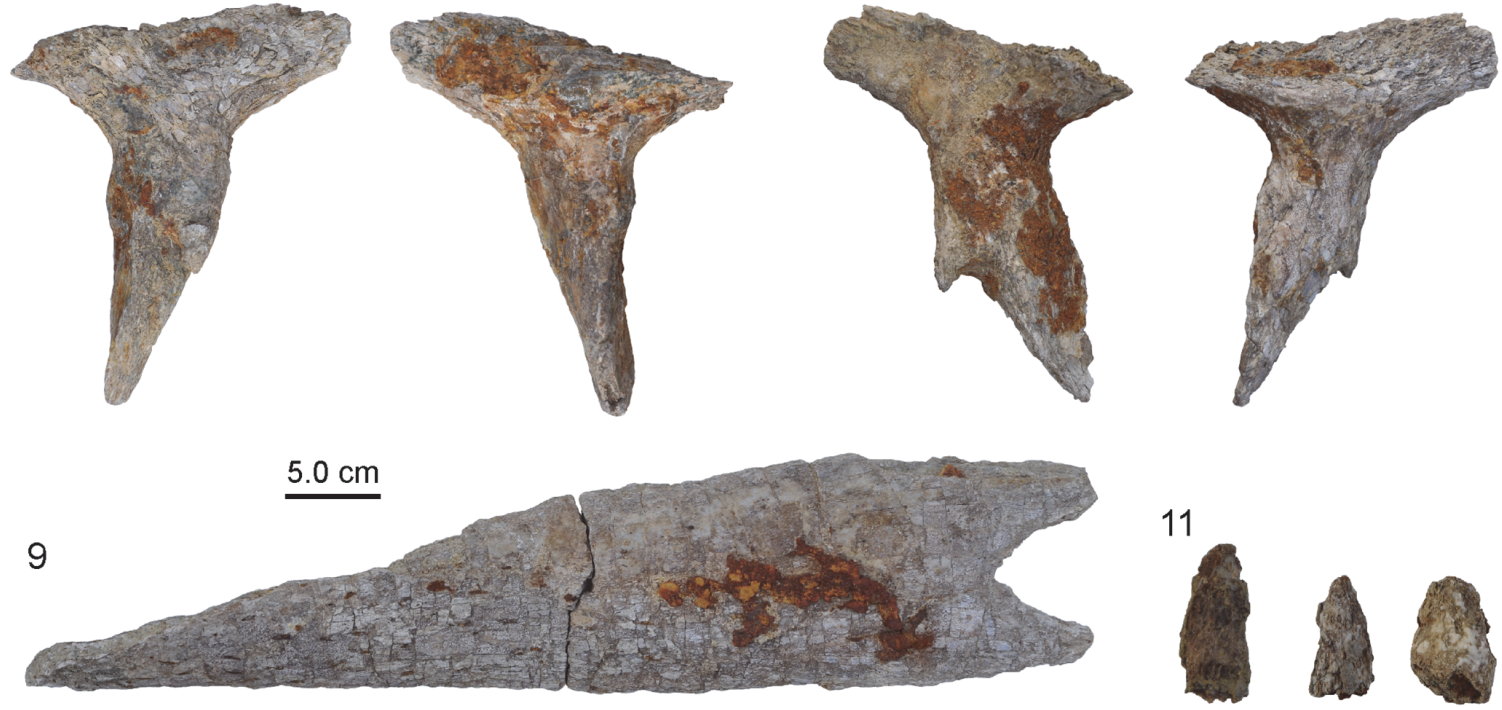

11

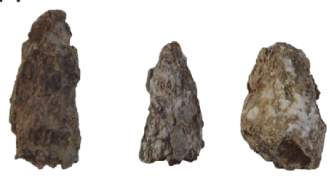

$2.0 \mathrm{~cm}$

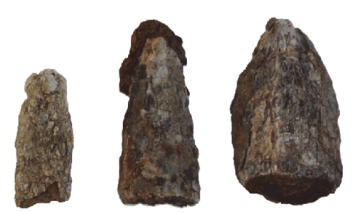

FIGURE 29. Photographs of associated cranial material (AMU-CURS-528) of Purussaurus cf. P. mirandai. 1-2, right premaxilla in dorsal (1) and ventral (2) view. 3-4, right jugal in lateral (3) and medial (4) view. 5-6, right ectopterygoid in ventral (5) and dorsal (6) view. 7-8, left ectopterygoid in ventral (7) and dorsal (8) view. 9-10, dentary fragment in external (9) and internal (10) view. 11, isolated teeth (note different scale bar).

The width of the teeth at the base ranges in diameter between $16 \mathrm{~mm}$ and $30 \mathrm{~mm}$, falling well into the range of the teeth accessioned as AMU-CURS033 (Aguilera et al., 2006).

Purussaurus sp. Barbosa-Rodrigues, 1892

Giant, massive, non-gavialoid cranial elements assignable to Purussaurus sp. are stored at UNEFM-CIAAP in Coro and the MCNC collections in Caracas (Figure 30), which are fragmentarily preserved and largely unprepared, such as specimens UNEFM-CIAAP-1434, MCNC-URU-76-72V, MCNC-URU-90-72V, and MCNC-URU-111-72V. The latter two specimens comprise also associated postcranial bones. Again, MCNC-URU-111-72V might constitute a mixed assemblage of several individuals, because there are at least two different sized cranial tables presented. Because of the 

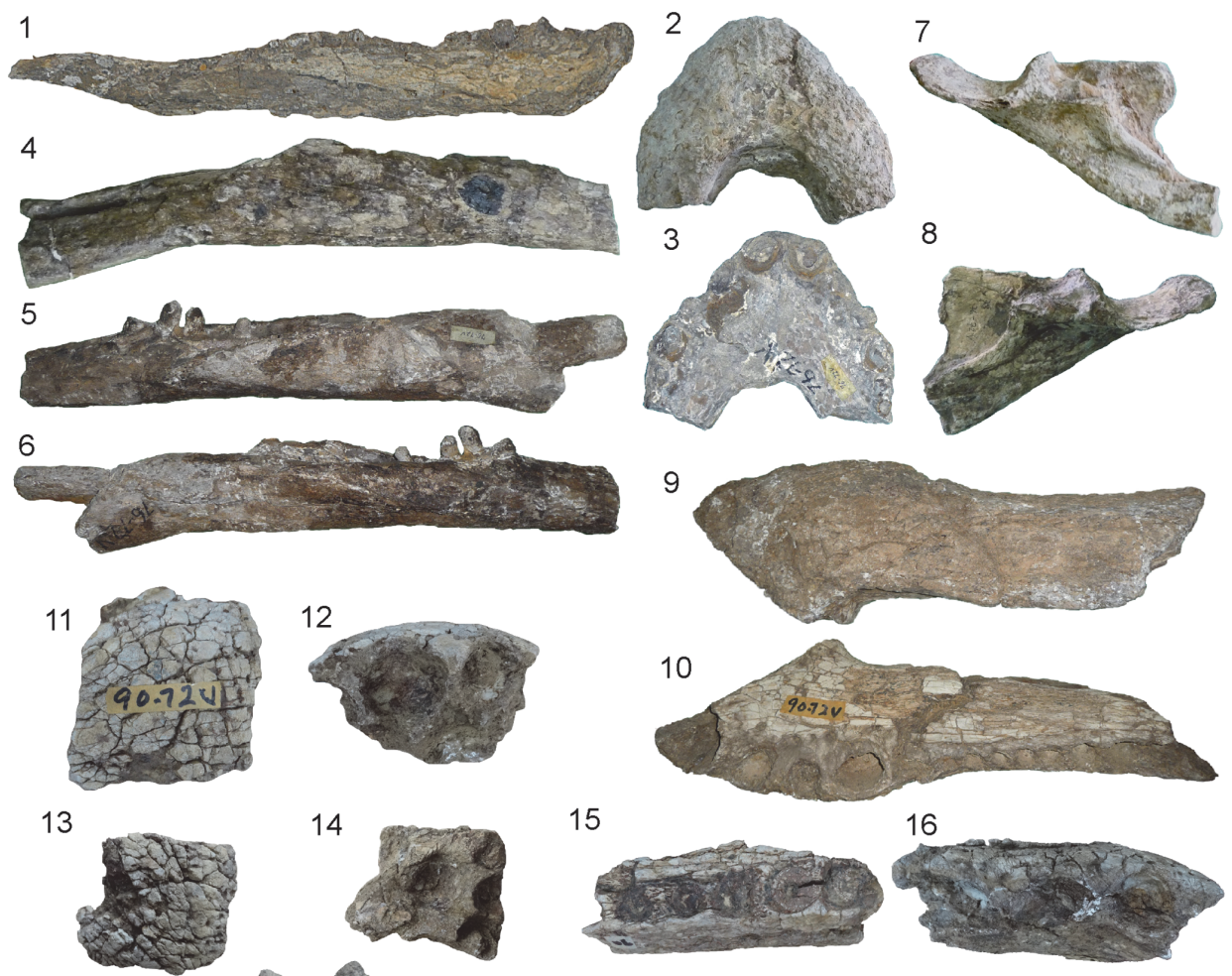

15
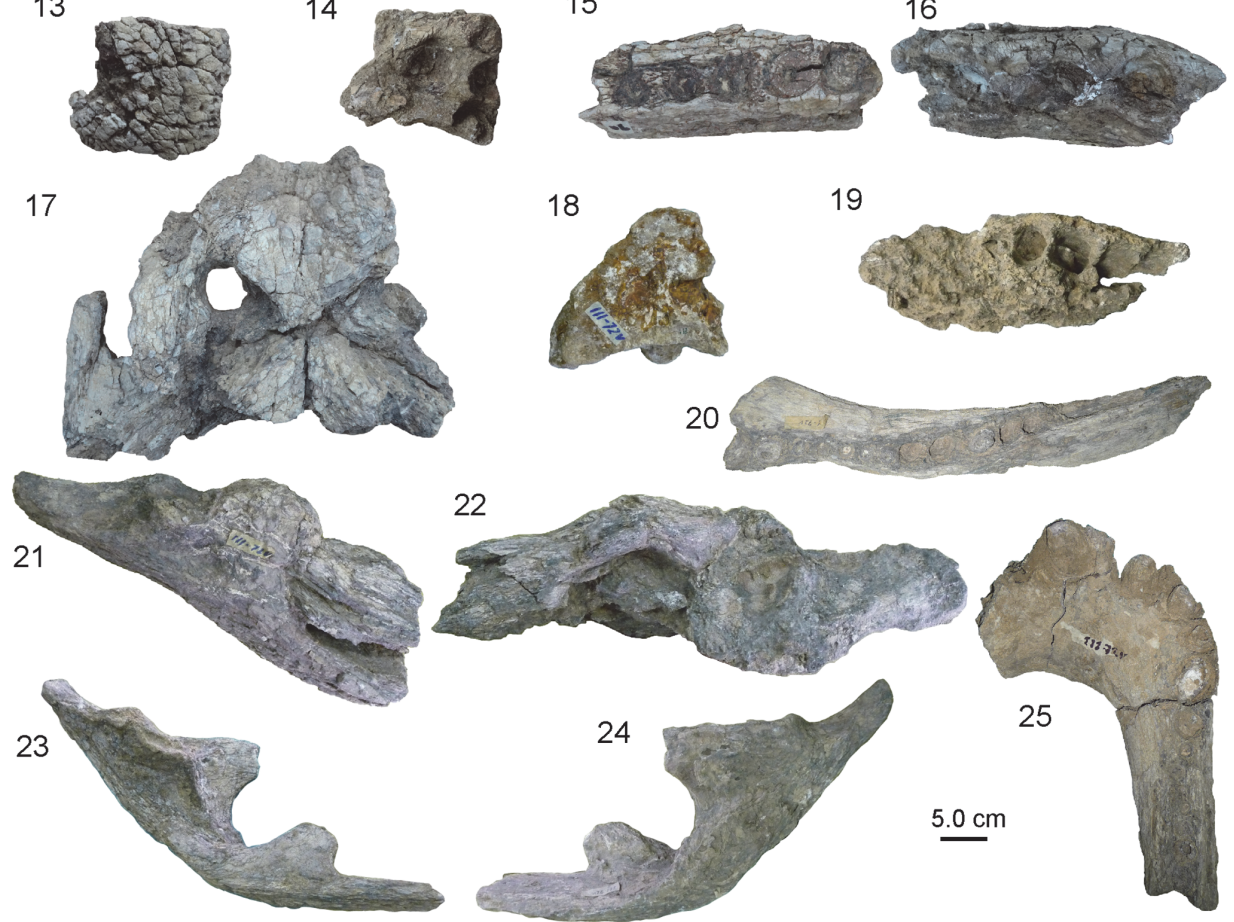

FIGURE 30. Photographs of cranial bones of several individuals of Purussaurus. 1, Strongly weathered lower jaw ramus (UNEFM-CIAAP-1434) in medial view. 2-7, associated lower jaw fragments (MCNC-76-72V). 2, 3, dentary symphyseal region showing the symphyseal region in ventral (2) and dorsal (3) view. 4-6, posterior portions of the left (4) and right dentary, the latter in medial (5) and lateral (6) view. Note that part of splenial is still attached to dentary in (5). 7, left articular, surangular and portion of angular in medial view. 8, right articular and surangular in medial view. 9-16, associated skull and lower jaw fragments (MCNC-URU-90-72V). 9, 10, left ramus in ventral and dorsal view. 1114, two premaxillary fragments in dorsal and ventral view each. 15, 16, two dentary fragments in dorsal view. 17-25, skull and lower jaw fragments (MCNC-URU-111-72V), which were found in an assemblage of at least two individuals of different size. 17, partial skull in dorsal view. 18, smaller partial skull in dorsal view. 19, strongly weathered maxillary fragment (?) in ventral view. 20, left dentary fragment in dorsal view. 21, 22, right articular and surangular in dorsolateral (21) and dorsal (22) view. 23, 24, left angular, surangular, and articular in medial (23) and lateral (24) view. 25, dentary symphyseal region and portion of right dentary in dorsal view. 

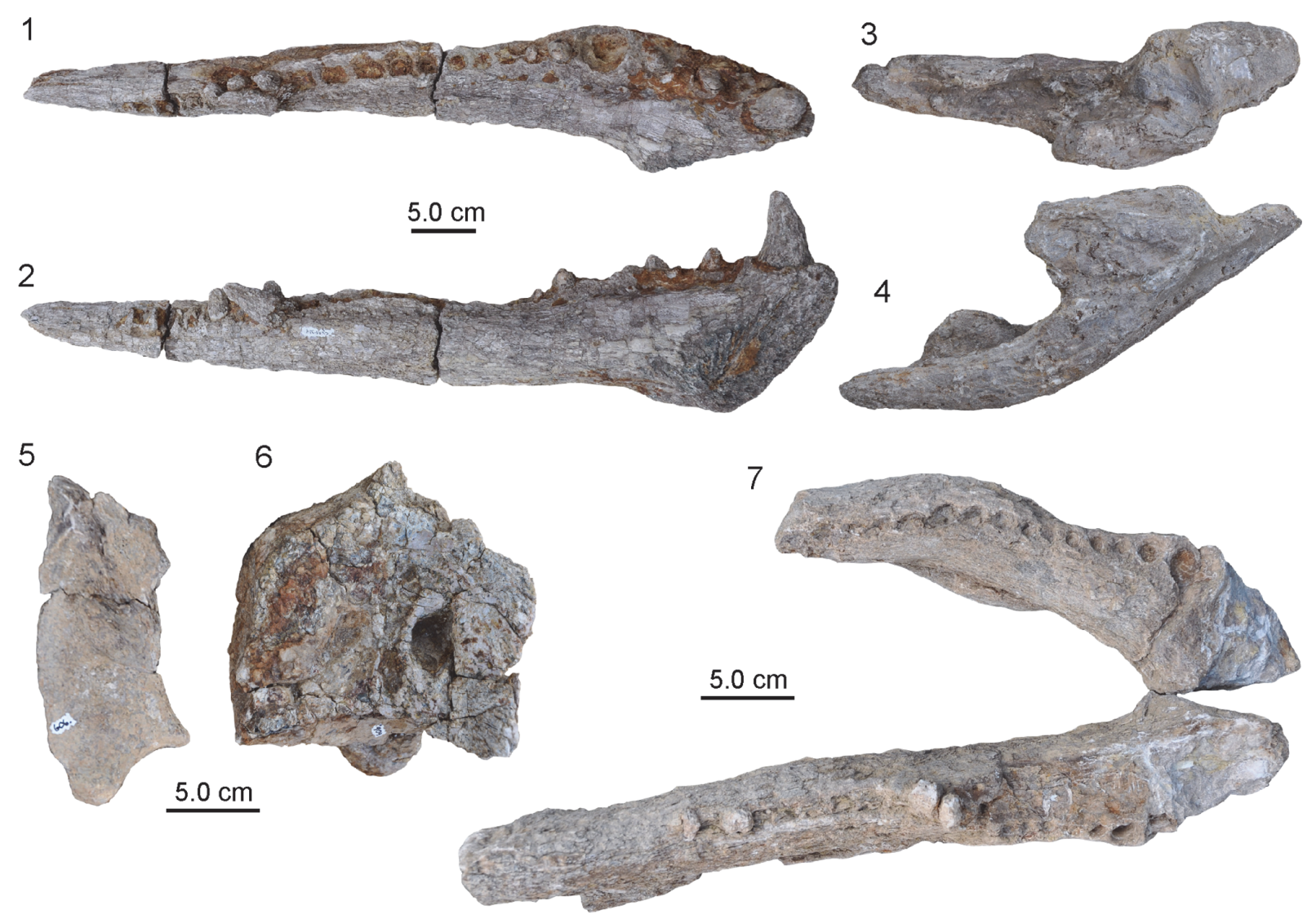

FIGURE 31. Cranial and lower jaw specimens of Purussaurus sp. 1-4, lower jaw fragments (AMU-CURS-384). 1, 2, left dentary in dorsal and medial view. 3, 4, left articular and angular in dorsal and lateral view. 5, 6, quadrate and skull table (AMU-CURS-606) in dorsal view. 7, dentaries of lower jaw (AMU-CURS-394) in dorsal view. Note the evident deformation of the left dentary.

poor state of preservation and/or preparation only selected specimens are presented here.

In addition, new or yet undescribed material assignable to Purussaurus sp. (due to their giant size and morphological congruence with described Purussaurus material) includes: 1) a fragmentary left mandible with most of the dentary and eight teeth preserved as well as the angular-surangulararticular complex (AMU-CURS-384; Figure 31.14); 2) a posterior skull portion and associated quadrate (AMU-CURS-606; Figure 31.5-6); 3) two associated anterior mandible fragments with a strongly deformed tooth row (AMU-CURS-394; Figure 31.7$)$; 4) a large anterior portion of a left mandible with the anterior-most 17 alveoli (which shows two generations of replacement teeth at broken cross-sectional surface) and the symphyseal portion of the right mandible preserving the first three and a half alveoli (AMU-CURS-671; Figure 32).

Seven isolated large teeth (AMU-CURS-006, 022, -033 [two specimens], -046, -101; UNEFM-
CIAAP 1432) have been found in the Urumaco Formation. Although we acknowledge that isolated teeth are usually not diagnostic and thus cannot be referred to a species or genus, in these cases, given their sheer dimensions and their asymmetrical, non-recurved built, we tentatively identify them as belonging to a giant caimanine, mostly likely to Purussaurus (Figure 33). The teeth range between $19 \mathrm{~mm}$ and $39 \mathrm{~mm}$ in diameter at their base, are slightly labiolingually compressed and carry mesiodistal carinae. In addition, AMU-CURS-006 appears to carry a wear facet on its medial side. Of the two teeth accessioned as AMU-CURS-033 only the smaller one has been figured previously in Aguilera et al. (2006).

Specimens AMU-CURS-162 (skull and lower jaw fragments) and -442 (lower jaw fragments associated with few postcranial remains including two osteoderms) have not been sufficiently prepared and are not shown here. 


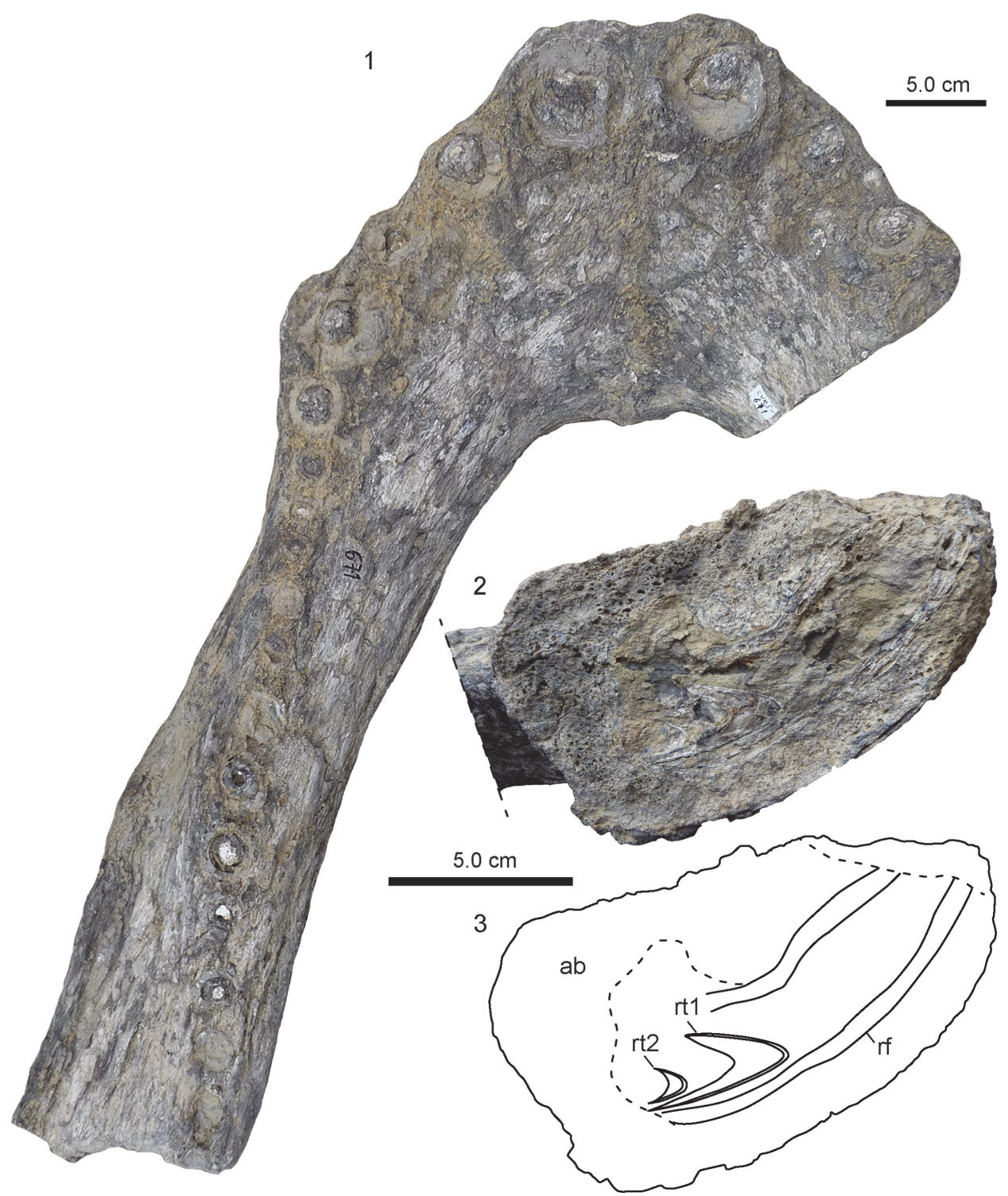

FIGURE 32. Photographs $(\mathbf{1}, \mathbf{2})$ of the anterior portion of the lower jaw of Purussaurus sp. (AMU-CURS-671) and interpretative drawing of the natural cross-section (3) of the right dentary. Abbreviations: ab, alveolar bone; rf; functional tooth; rt1, first replacement tooth; rt2, second replacement tooth.

Caimaninae indet.

Many of the specimens found in the Urumaco Formation are too weathered, encrusted (or even completely substituted) by gypsum crystals, or too fragmentary to allow generic and specific assignment, for which we tentatively assign those specimens to Caimaninae indet. herein. The following specimens (with the exception of AMU-CURS-090, $-100,-110$, and -601) are all identified as Caimaninae based on rather flat skull roofs, dermal bone rims overhanging the supratemporal fenestrae, and the presence of supraoccipitals (where identifiable) on the skull roofs.
AMU-CURS-090 (Figure 34) is a fragmentary lower jaw of about $15 \mathrm{~cm}$ length, heavily weathered, with at least 12 alveoli, and a single preserved posterior tooth. The jaw fragment is massive and deep as in Caiman brevirostris and Globidentosuchus brachyrostris, with the tooth having the appearance of a crushing tooth with a swollen crown. The specimen was previously labelled as "Caiman", but is here treated instead as Caimaninae indet. In agreement with caimanine morphology, this specimen shows a dorsal curvature posterior to the fourth dentary alveolus.

AMU-CURS-100 (Figure 35) is a badly weathered, short and stout anterior skull, and lower jaw 


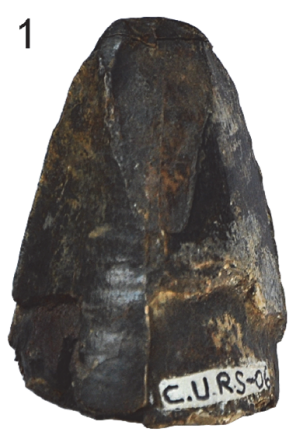

2

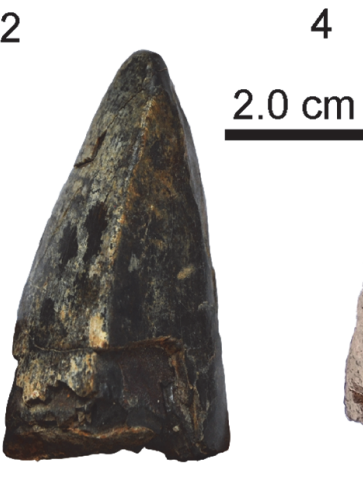

3

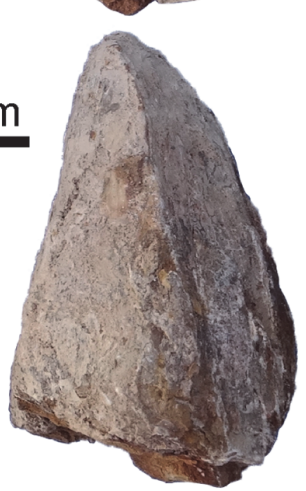

5

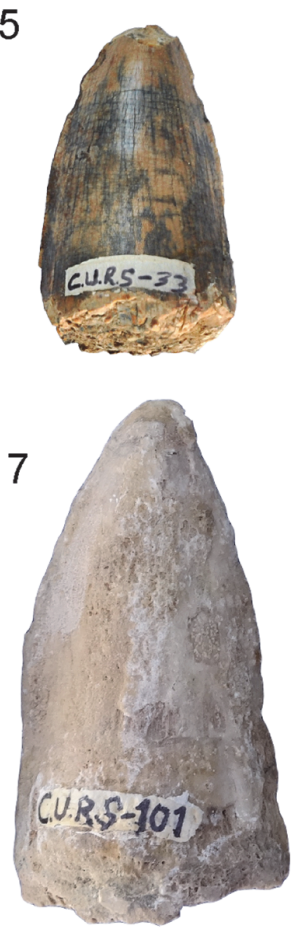

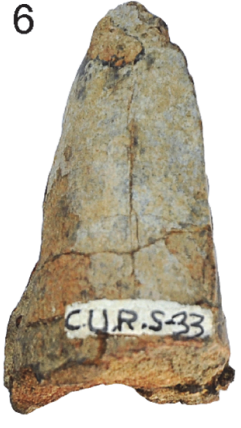

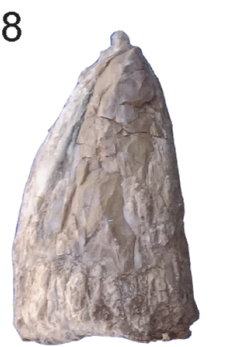

9

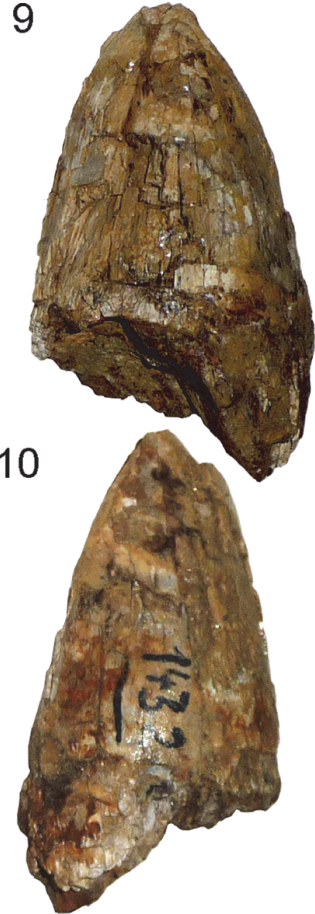

FIGURE 33. Photographs of isolated giant crocodylian teeth assignable to Purussaurus sp. All but the smallest specimen $(19 \mathrm{~mm})$ show maximal cross-sectional diameters between 27 and $39 \mathrm{~mm}$, which lie in the alveolar diameters of the largest Purussaurus specimens from Urumaco. 1, 2, tooth AMU-CURS-006 in rostral (1) and medial (2) view, carrying a wear facet. 3, 4, strongly weathered tooth AMU-CURS-046 in rostral (3) and medial (4) view. 5, 6, two teeth labelled AMU-CURS-033. 7, tooth AMU-CURS-101. 8, small tooth AMU-CURS-022. 9, 10, tooth UNEFM-CIAAP1432 in medial view.

fragment. It is tentatively referred to Caimaninae because of its overall resemblance of the robustness and shape of snout to Globidentosuchus (note also the presence of few robust globular upper jaw teeth; there is indication that the nasals reach the external narial opening). The posterior part of the skull and lower jaw is missing from about the posterior rim of the orbits. The specimen lacks further features which would allow assignment to the generic or specific level.

The specimen AMU-CURS-105/106 consists of a cranium and associated lower jaw material of a clearly durophagous caimanine from Tío Gregorio locality, uppermost Urumaco Formation. The material was previously labelled as Caiman brevirostris, prior to the description of Globidentosuchus brachyrostris (Scheyer et al., 2013). However, due to weathering and encrusting, there are no diagnostic features visible that would allow a clear identification to either of the two species and therefore the specimen is treated as belonging to Caimaninae herein (Figure 36).

AMU-CURS-110 (Figure 37) is a strongly weathered and gypsum-encrusted anterior part of a left lower jaw ramus $9.7 \mathrm{~cm}$ in length. Posteriorly, the anterior border of a large external mandibular fenestra is visible. Anteriorly, two robust teeth are mostly preserved, and a total of 16 alveoli could be counted forming a lightly sigmoidal tooth row. Two further broken tooth stumps in the posterior part of the tooth row indicate the presence of enlarged, closely spaced teeth in that part of the jaw. Whether the latter were conical or globular cannot be reconstructed. As in Globidentosuchus, the largest alveoli posterior to the fourth alveolus in the dentary is the thirteenth or fourteenth.

AMU-CURS-113 is the posterior part of a skull of a short-snouted caimanine (Figure 38). The specimen was referred to Caiman brevirostris and shown in left lateral view in Riff et al. (2010). The material, however, is heavily deformed and partially encrusted with gypsum, and the anterior part of the rostrum, the premaxillae, and the posterior part of the left quadrate and quadratojugal are missing. Furthermore, sutures between bones are not visible on the dorsal side of the skull. In the right maxilla, 12 alveoli are present, with the fourth being the largest. The alveoli posterior to the fourth form a 


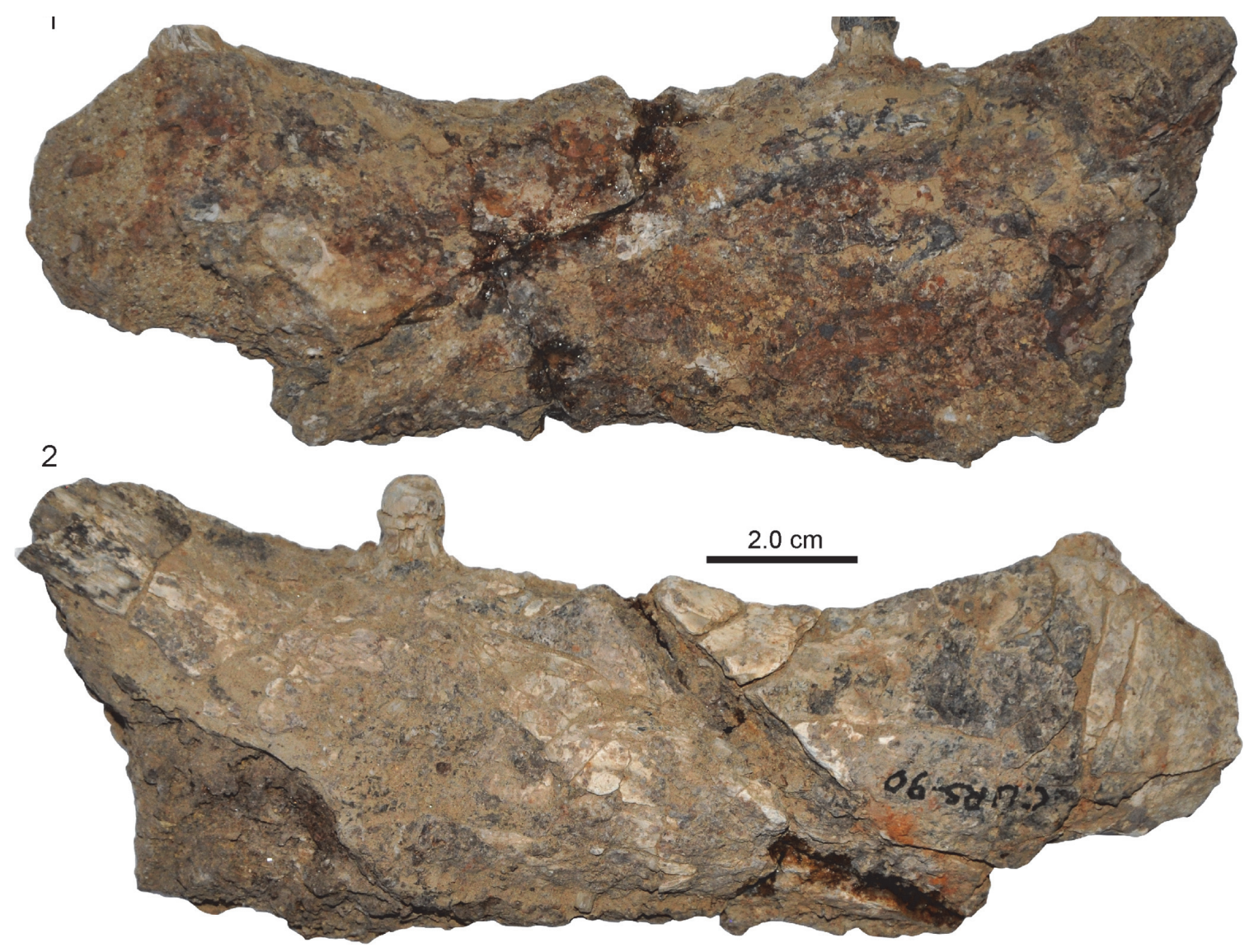

FIGURE 34. Photographs of caimanine lower jaw fragment (AMU-CURS-090) in lateral (1) and medial (2) view.

rather straight line and are not enlarged towards the back of the jaw, which argues against assignment to either of the durophagous species, C. brevirostris or Globidentosuchus brachyrostris (but is somewhat similar to the condition of the holotype skull MCNC-234 [field no. MCNC-URU-1-72V] of Melanosuchus fisheri; see Medina, 1976). The specimen also has only a small exposure of the supraoccipital on the skull table unlike in G. brachyrostris. Ventrally, the secondary palate and suborbital fenestrae are complete and, with the exception of the pterygoids, little deformed. Sutures between the premaxillae, maxillae, palatines, and pterygoids, however, are not traceable.

AMU-CURS-217, a skull and associated lower jaws from the Playa Larga locality (lower Middle Member of the Urumaco Formation) was listed by Scheyer et al. (2013) as belonging to Melanosuchus fisheri. Re-examination of the specimen revealed that osteological features are too far encrusted and substituted by gypsum minerals precluding assignment of the specimen to any genus or species.
The material AMU-CURS-429 from El Mamón locality, previously identified as Caiman brevirostris, is reconsidered herein as Caimaninae indet. (Figure 39.1-4). The posterior skull part and braincase was associated with a fragmentary maxilla and few postcranial elements (including two vertebral centra and a well-preserved femur). The alveolar spaces of the maxillary fragment are large and the interalveolar spaces small, indicating the presence of robust teeth as found in the durophagous species C. brevirostris and Globidentosuchus brachyrostris. The proportions of the skull table with rather small supratemporal fenestrae with overhanging rims would be consistent with those seen in caimanines, but clear diagnostic features are otherwise missing.

AMU-CURS-451 (Figure 39.5-7) is a weathered and partly encrusted, isolated skull table of a small caimanine from the Corralito locality, Urumaco Formation. The supraoccipital is small and has only a triangular to slightly trapezoidal exposure on the skull roof, unlike the large crescentshaped exposure seen in Globidentosuchus brachyrostris. A similar trapezoidal exposure is, 


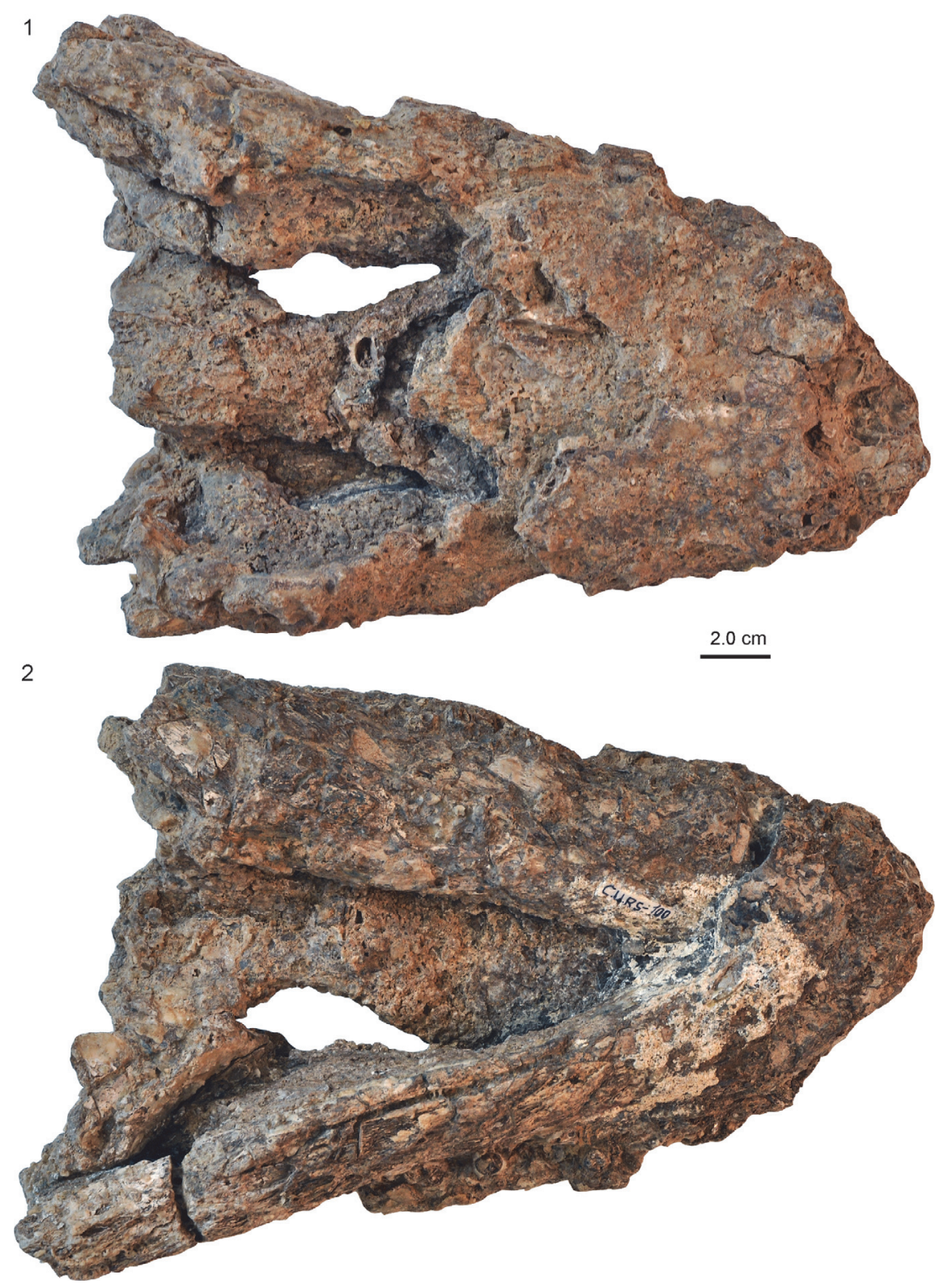

FIGURE 35. Photographs of heavily encrusted anterior portion of a partial caimanine skull and lower jaw (AMUCURS-100) in dorsal (1) and ventral (2) view.

however, present in MCNC-1829 (Caiman brevirostris). In addition, the specimen has only small supratemporal fenestrae with overhanging bone rims.

AMU-CURS-601 (Figure 40) is a weathered part of a small caimanine skull from 'North of El Picache' locality, Upper Member of the Urumaco Formation, consisting of a left articulated jugal and left partial quadratojugal. Anterior to the postorbital bar there appears to be an oval-shaped, sedimentfilled patch that could indicate the presence of a large jugal medial foramen as was described for
Globidentosuchus brevirostris (Scheyer et al., 2013). There is not a deep longitudinal trough between the jugal horizontal bar and the inset postorbital pillar, a usual character encountered in many caimanines.

The specimens UNEFM-VF-06 (from Tío Gregorio locality, Urumaco Fm.; Figure 41), -019, and 022 (both from El Hatillo locality, Urumaco Fm.), all represent isolated skull table and braincase remains in various stages of preservation and gypsum encrustation. UNEFM-VF-06 includes also two associated vertebral remains and UNEFM-VF- 

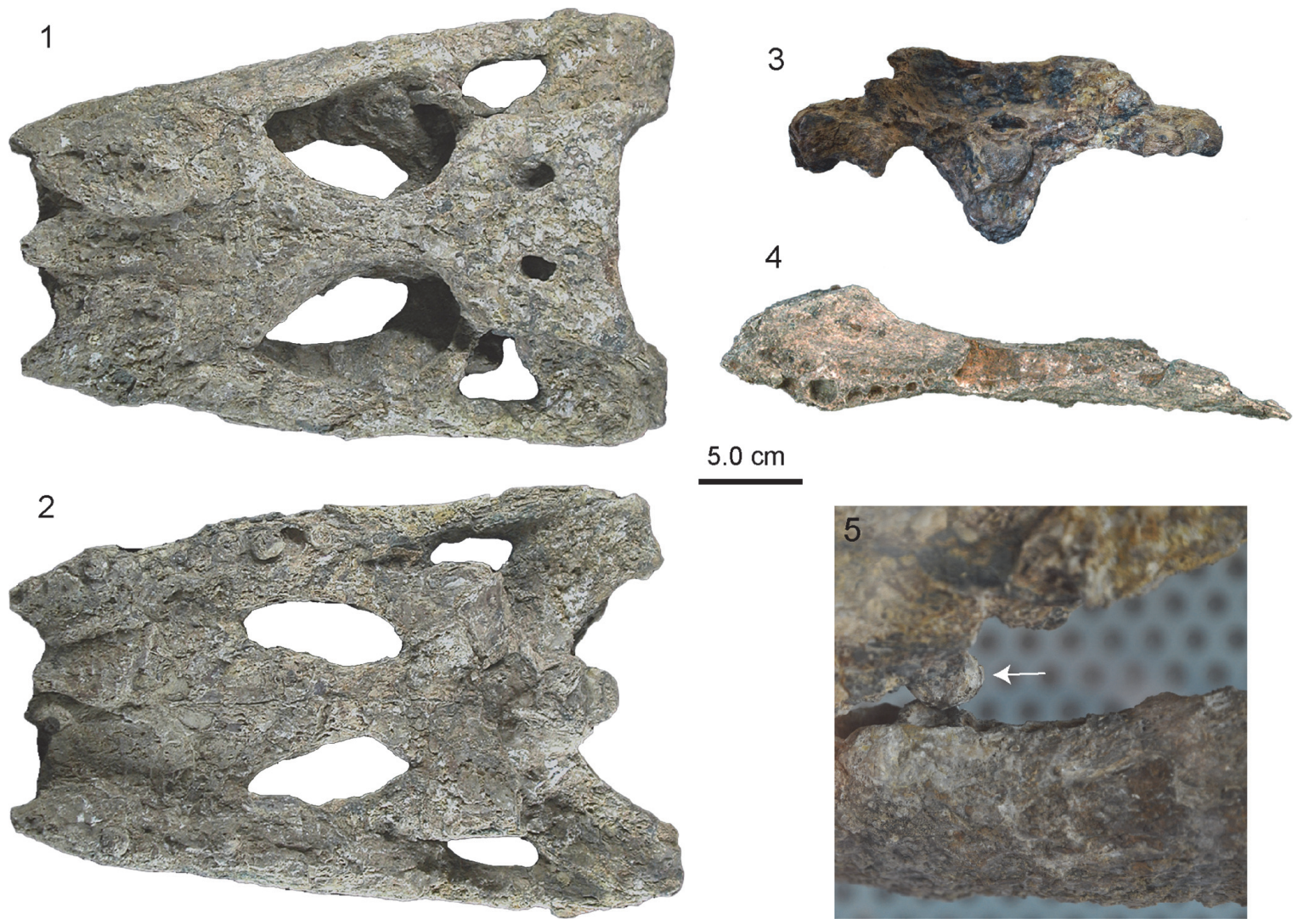

FIGURE 36. Photographs of skull $(\mathbf{1 - 3}, \mathbf{5})$ and associated lower jaw fragment $(4,5)$ of small Caimaninae indet. (AMUCURS105/106). 1, dorsal view. 2, ventral view. 3, occipital view. 4, left dentary in dorsal view. 5, Close-up of mounted specimen (not to scale) showing a preserved knob-like crushing tooth in the posterior part of the maxilla (marked by white arrow).

022 includes a single vertebra. UNEFM-VF-019 was previously identified as "Melanosuchus"; however, there are no diagnostic features visible that allow for such an assignment.

\section{DISCUSSION}

This revision of several hundred fossil caimanine specimens (Figure 1) from the Urumaco Formation allowed us to reassess the validity of previous identifications, as well as the identification of newly collected material as discussed in the following sections.

\section{Caiman brevirostris}

Previous to the description of the durophagous caimanine Globidentosuchus brachyrostris (Scheyer et al., 2013), most of the smaller caimanine remains with strong crushing dentition from the Urumaco Formation were identified as belonging to Caiman brevirostris. Apart from MCNC-1829, the specimens from the Urumaco Formation can- not be unambiguously attributed to $C$. brevirostris due to preservational bias causing a loss of diagnostic characters. We identify only a single specimen, MCNC-1829, as belonging to this species.

\section{Caiman latirostris and Caiman wannlangstoni}

Based on MCNC-URU-145-72V and AMUCURS-49, Aguilera (2004, p. 93) described the external naris in the extinct Caiman lutescens from Urumaco as being relatively small and heartshaped in comparison to that of the extant Caiman latirostris. Rovereto (1912), however, already mentioned that the length and shape of the nasals can be quite variable in the extant species (at least partly due to ontogenetic changes). This was corroborated by Bona and Desojo (2011), who pointed out that in some individuals of $C$. latirostris the nasals can be excluded from the external naris whereas, in other individuals, the nasals enter the external naris, creating a "heart-like outline" of the opening. Our re-analysis of AMU-CURS-049 and MCNC-URU-145-72V indicate that the specimens 


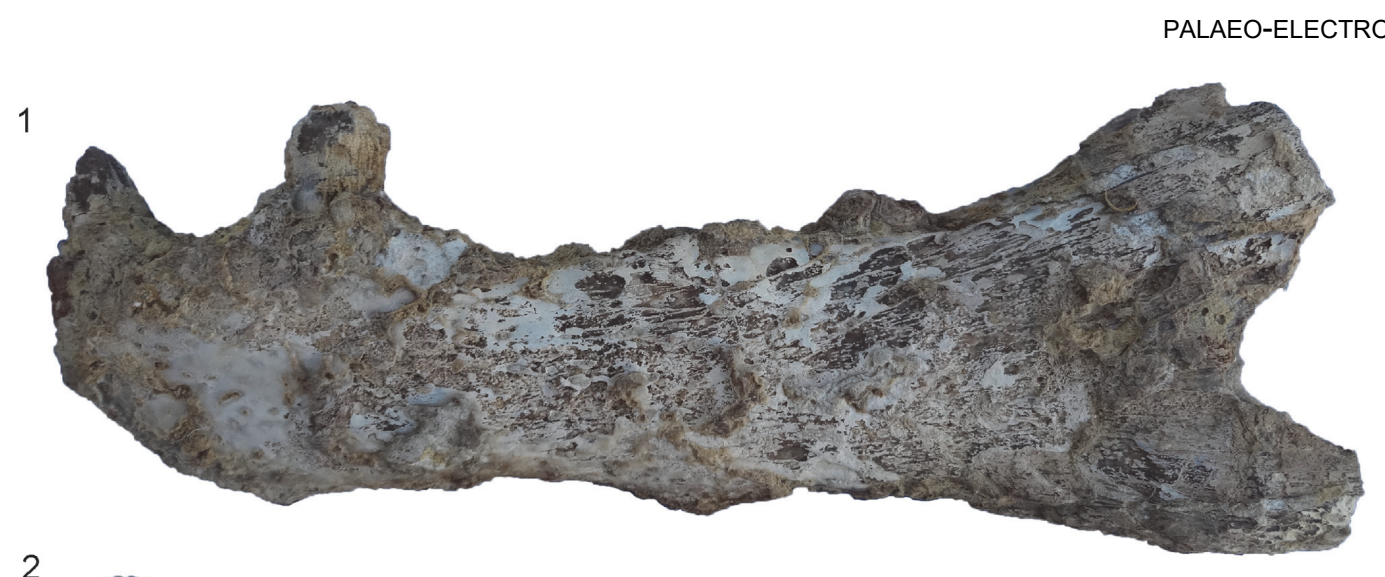

2
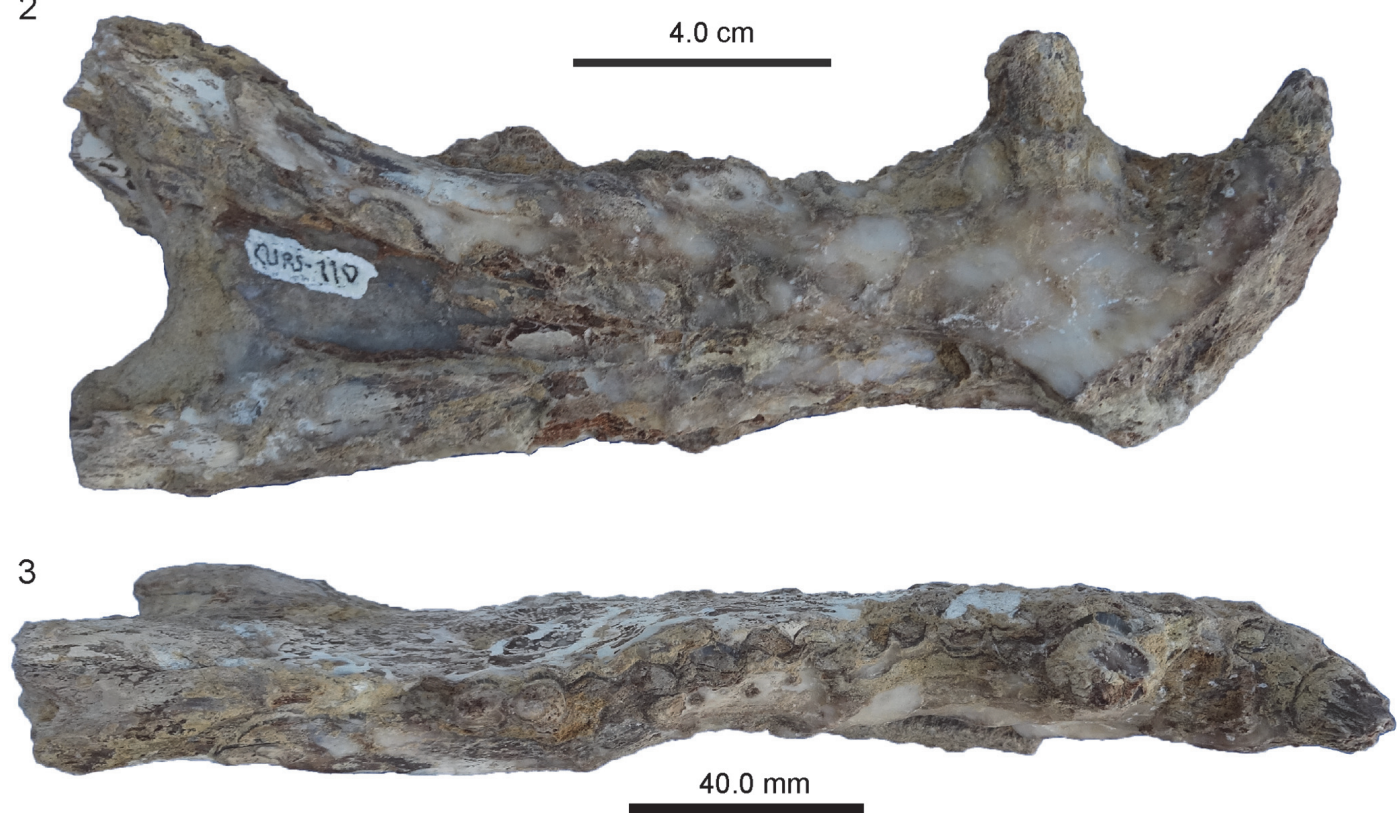

FIGURE 37. Photographs of heavily weathered and altered caimanine lower jaw fragment (AMU-CURS-110) in lateral (1), medial (2), and dorsal (3) view.

do not belong to the same taxon. The snout shape in MCNC-URU-145-72V is more consistent with $C$. latirostris (Bona and Desojo, 2011; personal obs. TMS on PIMUZ specimen) and corroborate the work of Riff et al. (2010) in substituting C. lutescens with $C$. latirostris in the crocodylian faunal list of Urumaco published previously (Scheyer and Moreno-Bernal, 2010; Scheyer et al., 2013). On the other hand, we agree with the assignment of AMU-CURS-049 to Caiman wannlangstoni as proposed by Salas-Gismondi et al. (2015), based mainly on the strongly sinuous lateral margins of the rostrum in dorsal view and the presence of tightly packed, large and globular posterior teeth in the specimen.

\section{Globidentosuchus brachyrostris and Globidentosuchus cf. G. brachyrostris}

The new material referred to Globidentosuchus brachyrostris and Globidentosuchus cf. G. brachyrostris present a refined look at the lower jaw morphology of the taxon, extending previous descriptions of the species (Scheyer et al., 2013). In particular, the more complete material of AMUCURS-067 allows the elucidation of the bone configuration in the posterior part of the mandible, as well as the size and shape of the external mandibular fenestra and the foramen intermandibularis caudalis (which are overall similar to that of the extant broad-snouted Caiman latirostris). Besides the crushing dentition, which consists of a unit of eight globular, tightly spaced teeth, and the participation of the splenial in the symphysis, the horizontal rather than an angled surangular-angular suture 

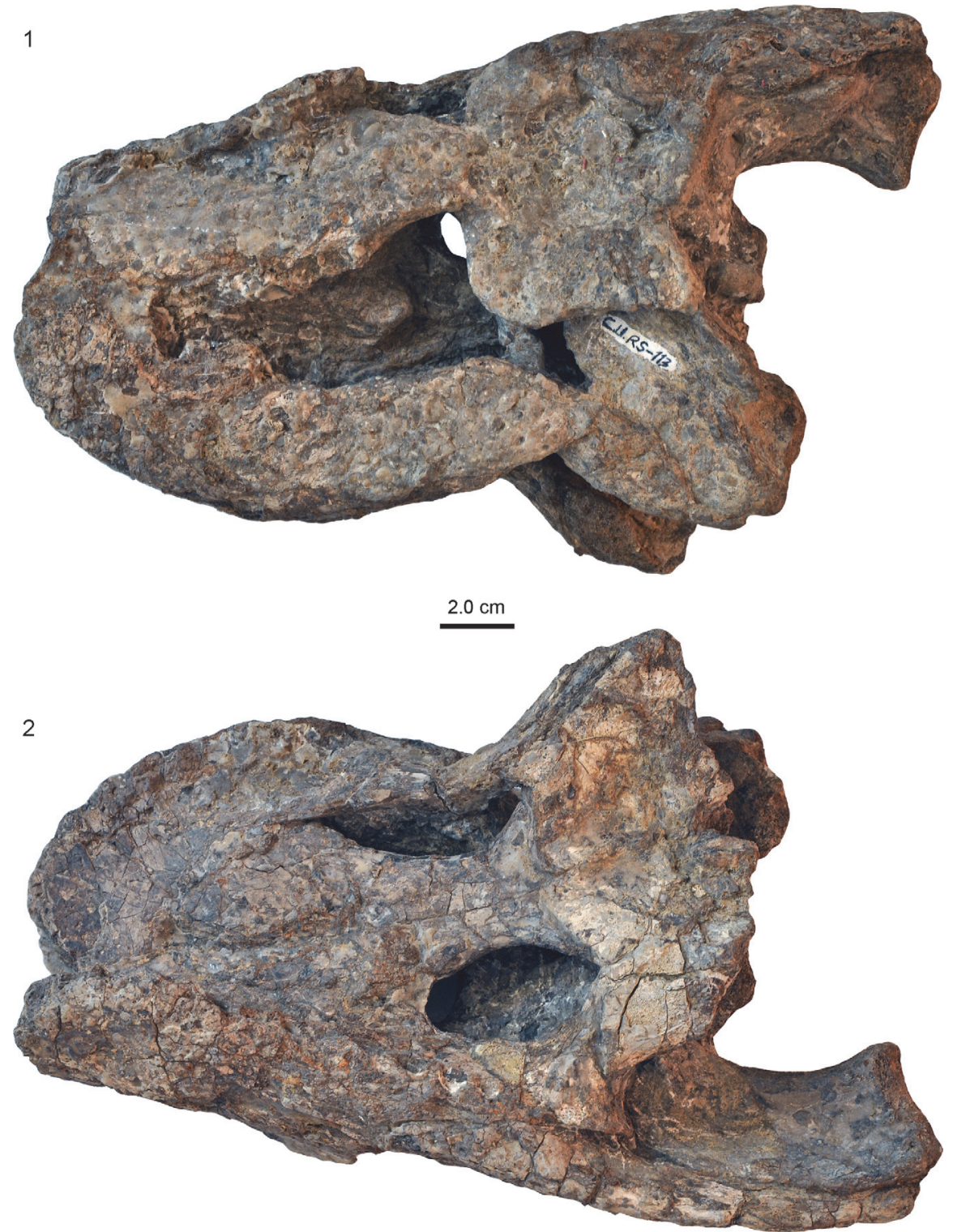

FIGURE 38. Photographs of strongly deformed partial caimanine skull (AMU-CURS-113) in dorsal (1) and ventral (2) view.

(in lateral view) is another consistent feature separating $G$. brachyrostris from $C$. brevirostris.

The inclusion of the new material expands the occurrence of the taxon to the Lower Member of the Urumaco Formation at the Bejucal Creek locality (AMU-CURS-083, -084), the lower Middle Member, Urumaco Formation, at the Playa Larga locality (AMU-CURS-67), as well as to the El Hatillo locality (UNEFM-VF-017) in the Upper Member of the Urumaco Formation.

\section{Caimaninae aff. Melanosuchus fisheri}

AMU-CURS-234 lacks crushing dentition, which precludes assignment to either Globidento- suchus brachyrostris or Caiman brevirostris. Furthermore, the less laterally expanded skull shape, the proportions of the skull table, and the diameter of the upper temporal fenestra, as well as the arching of the interorbital ridge are similar to those of the holotype skull of Melanosuchus fisheri (MCNC243) and MCZ 4336. Pending the revision of the holotype material of $M$. fisheri elsewhere, AMUCURS-234 is treated as Caimaninae aff. Melanosuchus fisheri herein.

\section{Mourasuchus}

Re-analysis of the material of both species in the Caracas, Coro, and Urumaco collections and 


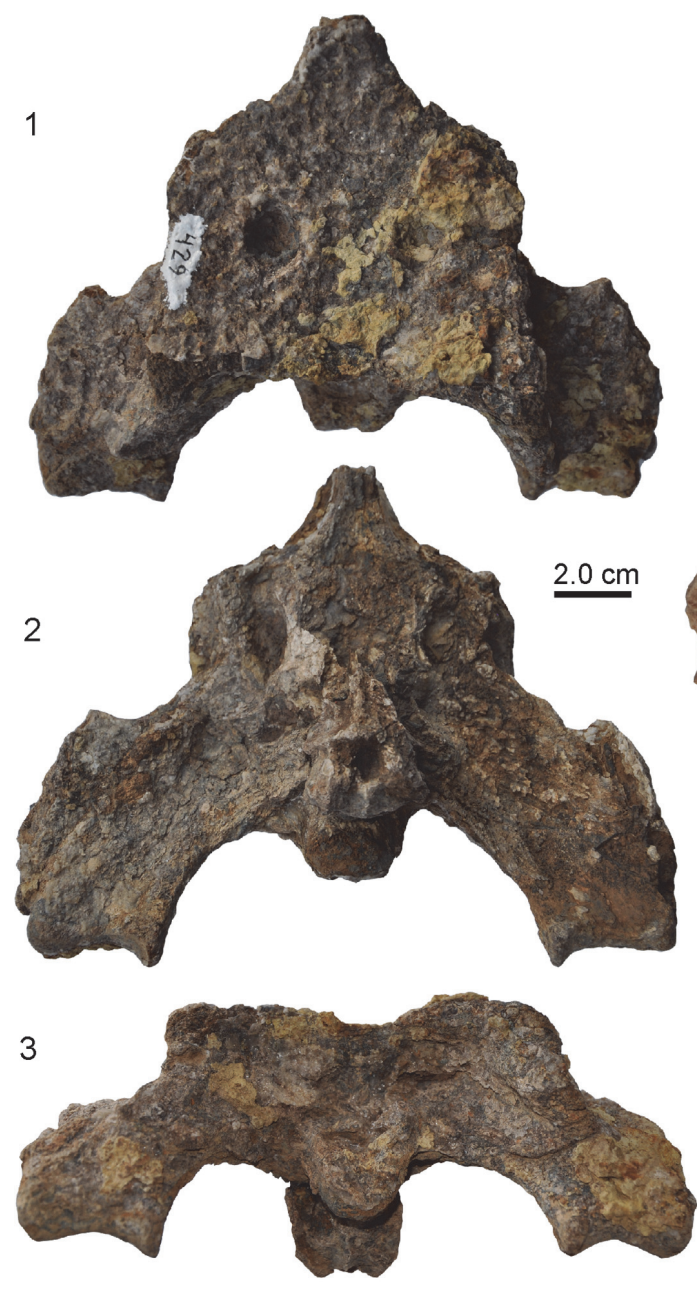

4

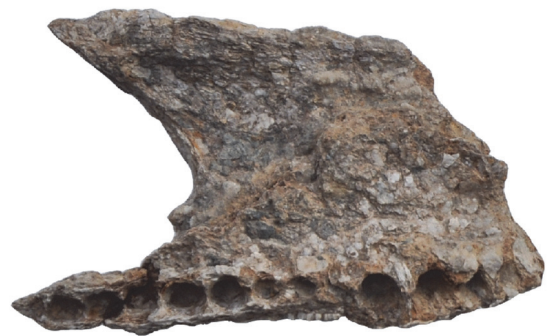

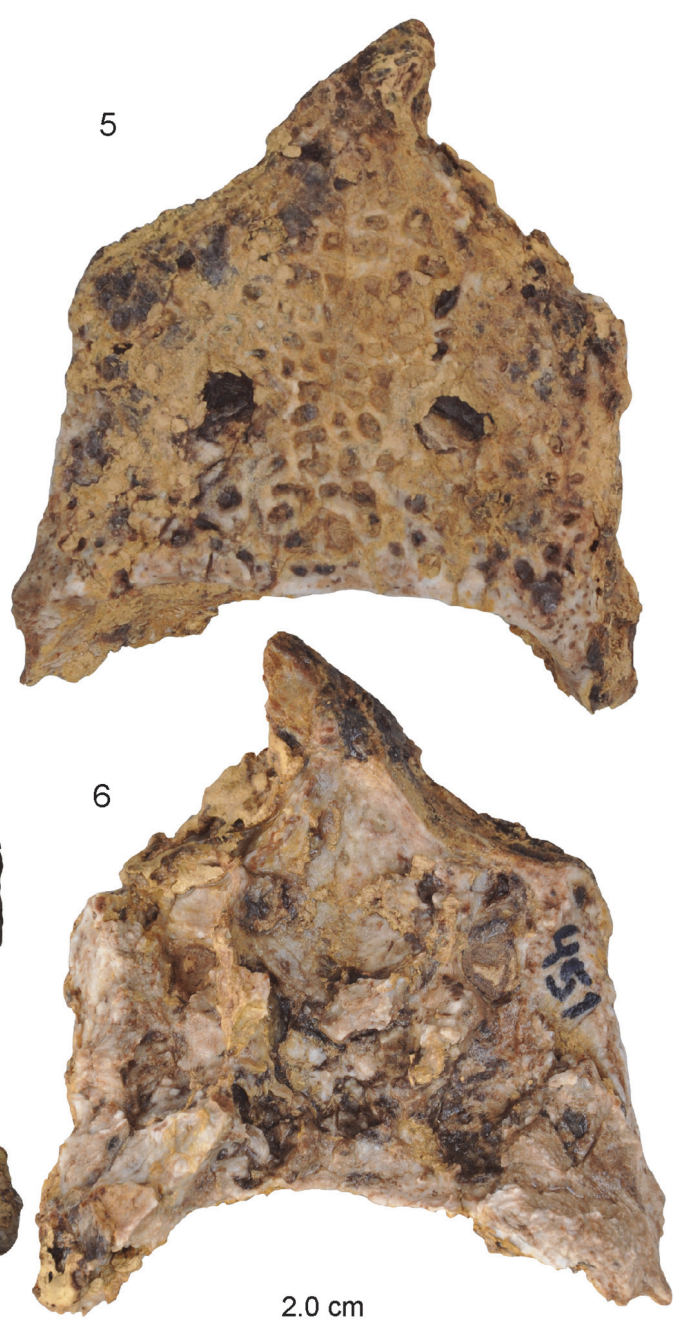

7

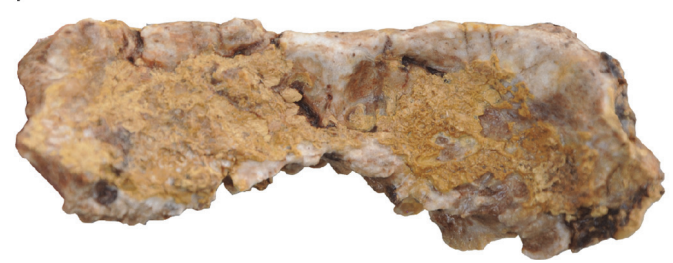

FIGURE 39. Photographs of remains including an associated posterior skull and maxilla fragments (AMU-CURS-429: 1-4) and a weathered and partly encrusted, isolated skull table of a small caimanine (AMU-CURS-451: 5-7). Posterior skull table and braincase in 1, dorsal, 2, ventral, and 3, occipital view. Maxillary fragment (4) in ventral view. Isolated skull table in dorsal (5), ventral (6), and occipital (7) view showing small exposure of supraoccipital on the skull roof.

comparison with the detailed anatomical study of other pertinent Mourasuchus material from other regions in South America (Bona et al., 2013a; Tineo et al., 2015) leads us to raise the question about the potential synonymy of the two species, $M$. arendsi and $M$. nativus. This is based on the fact that we found the posterior skull bone configuration and description of UNEFM-CIAAP-1297, the holotype skull of $M$. arendsi as reconstructed by Bocquentin Villanueva (1984), to be erroneous or ambiguous at best in several aspects. As such we interpret the dorsal skull bone configuration seen in $M$. arendsi (Figures 13, 14, 15, 16) to be much more similar to $M$. nativus than previously recognised. In the following, we list the most important anatomical aspects, on which we base the proposed synonymy of the two species:

1) Bocquentin Villanueva (1984) reconstructed the skull roof of the holotype of $M$. arendsi with a gentle concavity in occipital view, whereas a transverse 

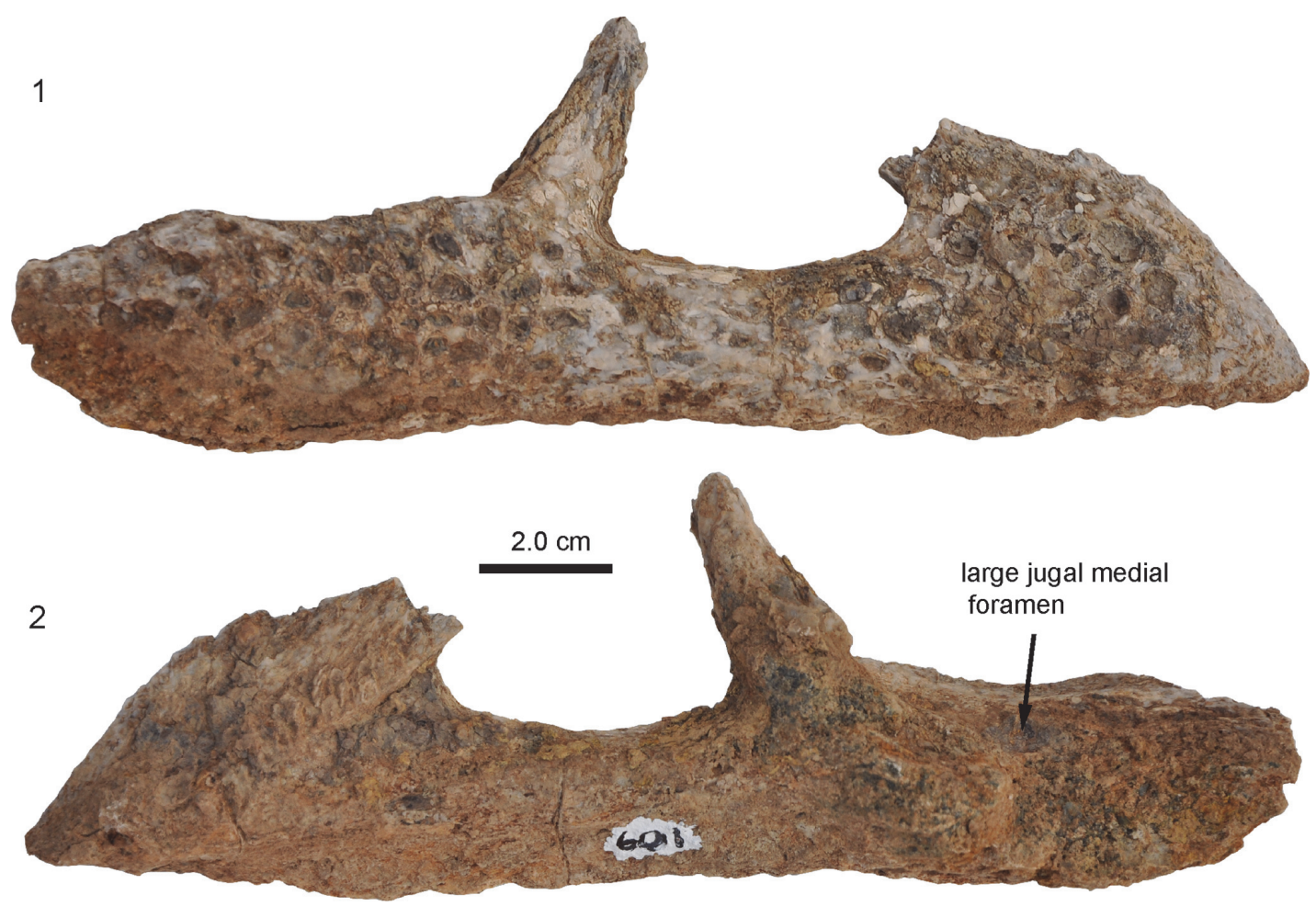

FIGURE 40. Photographs of small caimanine skull part (AMU-CURS-601) consisting of an articulated left jugal and partial quadratojugal in lateral (1) and medial (2) view.

robust ridge with prominent squamosal eminences was thought to be diagnostic for $M$. nativus (Gasparini, 1985). Variation in the height and development of these eminences among different specimens (of different ages) was interpreted as pertaining to sexual dimorphism (Gasparini, 1985), ontogenetic growth variation linked to overall size (Bona et al., 2013a), or thought to be connected to a "significant amount of superficial vasculature associated with the skull roof [...] a concept forwarded by Gasparini (1985) for the genus "Carandaisuchus."” (Bona et al., 2013a, p. 238). Reanalysis of UNEFM-CIAAP1297 reveals that the specimen also had moderately developed squamosal eminences forming an incised V-shaped valley (Figure 16). The skull of MCNC-URU-110-72V does not offer more information in this regard, because its skull table is completely reconstructed by plaster so that neither the posterior transverse ridge nor the squamosal eminences are original bone.

2) Four perforations of the premaxilla are present anteriorly and laterally to the external naris in the holotype skull UNEFM-CIAAP-1297 (also in AMUCURS-395). Langston, (1965) showed interpretative drawings of the premaxilla of Mourasuchus atopus (type specimen UCMP 38012) from the Miocene of La Venta, Colombia, in which only the first and fourth tooth in each mandible pierced its respective occlusion pit; the second and third occlusion pits remained covered with bone. In contrast to $M$. atopus, the diameter of the perforations decreases slightly from the first to the fourth in the Urumaco specimens, which fits with a small but continuous decrease of the alveolar diameter of the four anterior-most teeth in the lower jaw (i.e., AMU-CURS073). It cannot be stated with confidence whether the four pits in the specimens from Urumaco similarly resemble true perforations of the premaxilla that occurred during life, or if the bone covering the occlusion pits was fully or at least partly eroded in the heavily weathered fossils. It also remains unclear whether the number of teeth perforating the premaxilla in Mourasuchus from Urumaco increases during ontogeny, a notion also discussed in Langston (2008). Furthermore, there is no good description of the anterior rostral portion of the skulls of $M$. nativus from Argentina, which precludes comparison (Bona et al., 2013a). Therefore, pending better preserved findings, taking the perforations as a diagnostic feature separating $M$. arendsi from other species of Mourasuchus should be treated with caution.

3) Similar to Mourasuchus nativus (Bocquentin and Souza Filho, 1990) there is a small but evident sagittal crest on the postero-dorsal surface of the parietal, which had not been noted before in the holotype (UNEFM-CIAAP-1297) of M. arendsi. A crest is also present in specimen AMU-CURS-218. 

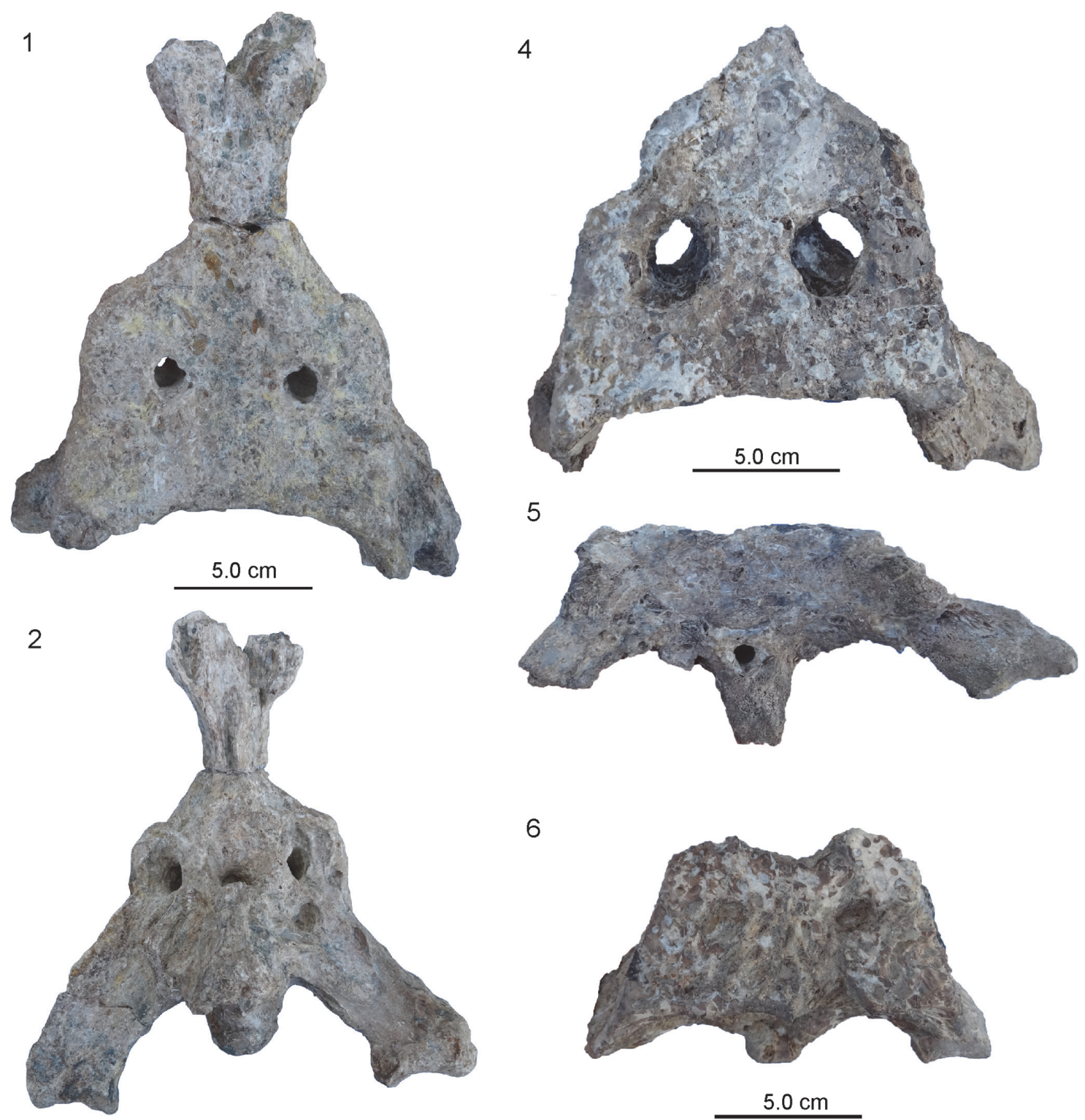

6
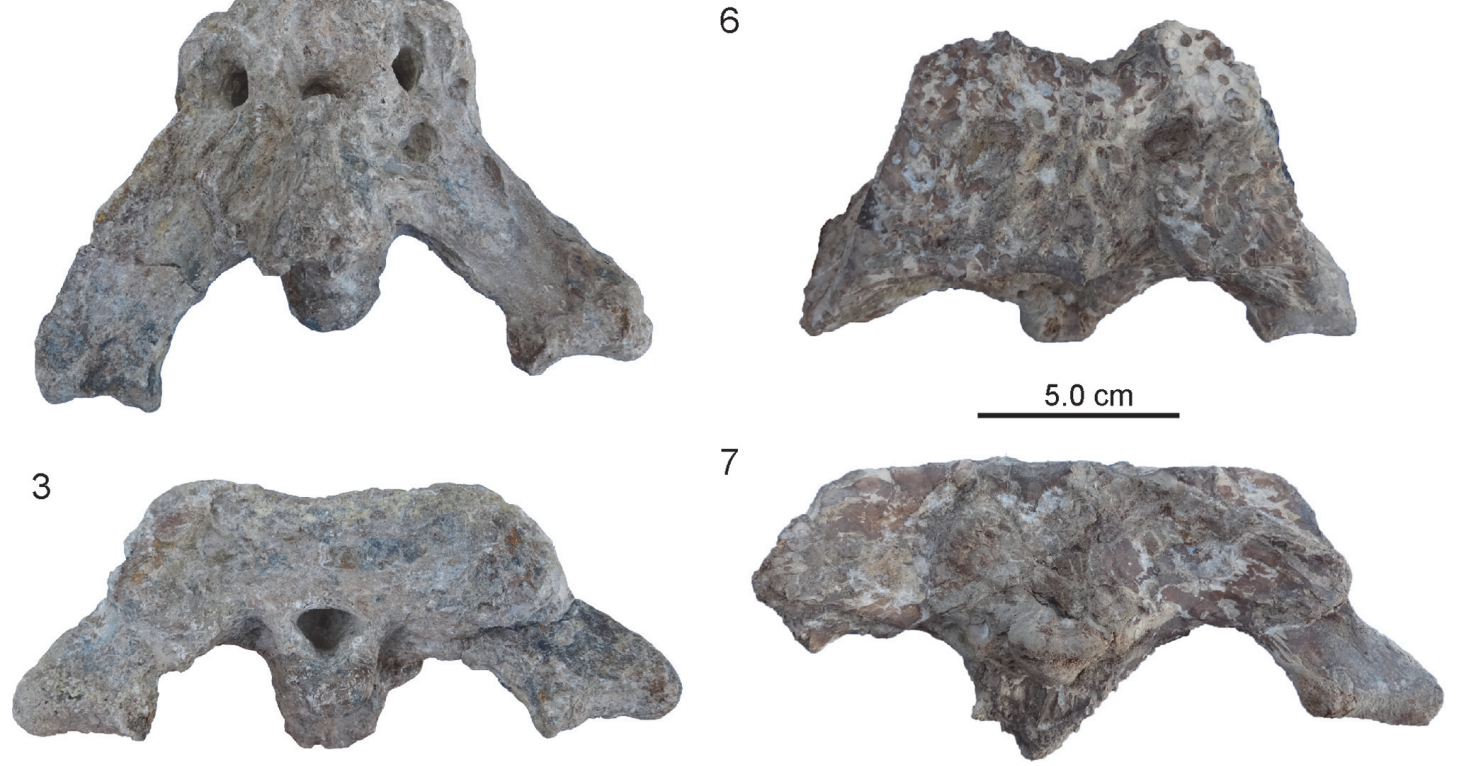

FIGURE 41. Photographs of small caimanine skull roofs. A-C, UNEFM-VF-06 in dorsal (1), ventral (2), and occipital (3) view. 4, 5, UNEFM-VF-019 in dorsal and occipital view. 6, 7, UNEFM-VF-022 in dorsal and occipital view.

4) The nerve openings of the braincase were regarded as diagnostic for Mourasuchus nativus (Bona et al., 2013a). Unfortunately, the material of $M$. arendsi from Urumaco is insufficiently preserved to allow a detailed comparison of these features.
5) The presence of a notch at the lateral edge of the jugals separates Mourasuchus amazonensis and $M$. nativus from $M$. atopus, the latter lacking this anatomical feature (see Table 1). Our reanalysis shows that the holotype of $M$. arendsi also has a clear 
notch when the broken off jugals are rotated dorsally, back into their natural position. A clear notch is also present in another specimen (MCNC-URU-110$72 \mathrm{~V}$ ), tentatively assignable to $M$. arendsi.

6) The absence of raised bony knobs at the rostral orbital margins has been stated before to separate Mourasuchus nativus from the three other species: $M$. amazonensis, $M$. atopus and $M$. arendsi (Bona et al., 2013a). Salas-Gismondi (2015), however, showed a set of highly prominent eminences in specimen MUSM 2378 attributed to M. atopus from Peru, which indicates that the lack of eminences is restricted only to $M$. amazonensis. However, since this is isolated material its assignment to $M$. atopus remains questionable. In addition, AMU-CURS-218 from the Urumaco Formation has both raised orbital rims (the right is mostly broken off) and very prominent, raised bony knobs anteromedial to the orbits (Figure 19), situated on the prefrontals. In UNEFMCIAAP-1297, the orbital rim is extremely developed at the anteromedial sector, but the ridge continues along the orbit in the interorbital region. This ridge is much less developed in the lateral sector of the orbit, but it is clear that the orbital rim is also distinctly raised laterally. This is clearly visible on the right orbit, but the part which is preserved on the left orbit confirms what is visible on the right side. As the bony knobs at the orbital margins might not appear in all specimens (i.e., in the holotype of $M$. arendsi and referred specimen AMU-CURS-218 of $M$. nativus), we would like to raise the possibility that these bony excrescences are a potential sexually dimorphic feature (compare to the soft-tissue narial excrescences, the ghara, of larger male Gavialis gangeticus; Martin and Bellairs, 1977).

7) Bocquentin Villanueva (1984) noted that in Mourasuchus arendsi the palatine bones are expanded more transversely between the suborbital fenestrae than in $M$. atopus, although Langston (1966) pointed out the possibility that the holotype of $M$. atopus may represent a juvenile specimen. As such, this feature may vary throughout ontogeny and it might also vary intraspecifically with the species of Mourasuchus. Furthermore, this feature is not present in the holotype MLP 73-IV-15-8 (or in the referred specimen MLP 73-IV-15-9) of $M$. nativus (Bona et al., 2013a, b). For now, the small sample size and poor preservation of many specimens hamper the usage of this character, and so it is treated as insufficient to separate species of Mourasuchus herein.

As outlined above, the presence/absence of: 1) squamosal eminences, 2) pronounced knobs at the orbits, 3) a prominent notch of the jugals, and 4) a median crest or ridge on the parietal are not sufficient to separate Mourasuchus arendsi (Bocquentin Villanueva, 1984) from M. nativus (Gasparini, 1985); and based on this synonymy $M$. arendsi would have priority. In summation, there could be only three separate species of Mourasuchus in South America: M. amazonensis from the late Miocene of Brazil, M. atopus from the middle Miocene of Colombia and likely Peru, and M. arendsi from the late Miocene of Argentina, Brazil and Venezuela. In addition, the genus Mourasuchus is also known from the late Miocene of Bolivia. As such, the dispersal of Mourasuchus over large areas of the South American continent could have started with the arrival of a Palaeogene ancestral form arriving from North/Central America (alternatively Mourasuchus could be an endemic taxon that evolved on the South American continent). During the mid-Miocene, Mourasuchus could then have spread from the proto-Amazonian areas of Colombia and Peru eastward, and inhabiting Venezuela and then Brazil and Argentina during the late Miocene.

\section{Purussaurus mirandai}

According to our revision and based on ongoing fieldwork, Purussaurus is considered to be a common element in the crocodylian community that is preserved in the Urumaco Formation. Many of the new, better preserved specimens can be assigned to Purussaurus mirandai or cf. P. mirandai, which so far appears to be the only species of Purussaurus present in Venezuela. We also tentatively refer AMU-CURS-541 from the 'North of EI Picache' locality to Purussaurus cf. P. mirandai herein, because of the congruence with the holotype of $P$. mirandai. As in the holotype, the dentary is slightly wavy in lateral view and carries a tooth row with 21 alveoli, and the splenial reaches anteriorly to the eigth alveolus forming a medial border of the alveoli from the sixteenth to the twenty-first alveolus backwards. In addition, the position of Purussaurus within Caimaninae could be corroborated by identifying an ectopterygoid-pterygoid flexure in an adult specimen (AMU-CURS-528).

On the other hand, we noted several inconsistencies between the MCNC paratype material listed by Aguilera et al. (2006) and the original field notes by the 'Harvard expedition' (Patterson et al., 1972). Accordingly, instead of the cranial material (a right premaxilla and maxilla in ventral view) shown in Aguilera et al. (2006, figure 3B), the field notes list only a single "part of symphysis" under MCNC-URU-115-72V (Figure 25.1). Although still being assignable to Purussaurus, MCNC-URU$115-72 \mathrm{~V}$ is not considered to be part of the paratype series of $P$. mirandai. We further hypothesise that the anterior skull fragments shown in Figure 
25.2-4 belong to MCNC-URU-158-72V instead of MCNC-URU-115-72V, because of the description in the 'Harvard expedition' field notes ("skull and jaw, disarticulated"; Patterson et al., 1972), the overall size of the bones, as well as the non-overlap with the remainder of the cranial bones labelled under that number (shown in Figure 25.5-21). Also, MCNC-URU-158-72V likely represents a mixed assemblage of several Purussaurus individuals. In addition, the 'Harvard expedition' field notes list a large number of postcranial remains of a "giant crocodile" under MCNC-URU-157-72V, and not a "dentary" as noted in Aguilera et al. ( 2006, p. 224; also erroneously figured under that number in Aguilera, 2004, page 91). We hypothesise that the two lower jaw fragments shown in Figure 25.23 complement MCNC-URU-158-72V, again based on the size of the specimen, non-overlap with other fragments, and lack of other data from the field notes that would indicate otherwise. In this case, the MCNC paratype material indicated in Aguilera et al. (2006) all would derive from MCNC-URU-158$72 \mathrm{~V}$.

\section{CONCLUSIONS}

We represent here the first overview of caimanine material from the Urumaco Formation, which was collected and accessioned in major repositories (MCNC, UNEFM-CIAAP, and AMUCURS) up until the end of 2015. Our revision revealed a rich fossil record of caimanine cranial and lower jaw material from the Urumaco Formation, with many specimens reported for the first time. The material can be referred to the extant genera Caiman and (with doubt) Melanosuchus, as well as the extinct genera Globidentosuchus, Mourasuchus, and Purussaurus. Although the taxonomic identity of many specimens needed adapting, the very rich diversity of the crocodylian fauna that was previously reported could be corroborated.

\section{ACKNOWLEDGEMENTS}

We thank R. Sánchez (STRI) and J. Carrillo (AMU) for all their support and guidance in Venezuela. H. Moreno and J. Gamboa (MCN), I.A. Hernández (UCV), A. Pulgar (UNEFM), H. Furrer, and C. Klug (PIMUZ), and the Alcaldía Bolivariana del Municipio Urumaco are thanked for access to specimens under their care. M. Sánchez and all student participants of Bio266 (UZH, November 2013) are thanked for their various helps during field work. J. Carrillo (AMU), A. Hastings (VMNH), and R. Salas-Gismondi (Zurich) are thanked for discussions. O. Aguilera (UFF) and J. Moreno (Univ. de Colombia, Bogotá) kindly provided images of specimens of 'Caiman brevirostris' and Purussaurus mirandai. We thank the editors A. Souron, K. Black, J. Louys, and J. Rumford, and J. Neenan for checking the English of the manuscript, as well as D. Fortier and one anonymous reviewer for their valuable comments. This research was partly funded by the Swiss National Science Foundation (grant no. 149506 to TMS). MD acknowledges support by University of Torino (Fondi di Ateneo 2014-2015) and Generalitat de Catalunya (2014 SGR 416 GRC).

\section{REFERENCES}

Aguilera, O.A. 2004. Tesoros Paleontológicos de Venezuela: Urumaco, Patrimonio Natural de la Humanidad. Editorial Arte, Caracas.

Aguilera, O.A., Riff, D., and Bocquentin-Villanueva, J. 2006. A new giant Purussaurus (Crocodyliformes, Alligatoridae) from the upper Miocene Urumaco Formation, Venezuela. Journal of Systematic Palaeontology, 4:221-232.

Aureliano, T., Ghilardi, A.M., Guilherme, E., Souza-Filho, J.P., Cavalcanti, M., and Riff, D. 2015. Morphometry, bite-force, and paleobiology of the late Miocene caiman Purussaurus brasiliensis. PLoS ONE, 10(2): e0117944. doi:10.1371/journal.pone.0117944

Barbosa-Rodrigues, B. 1892. Les reptiles fossiles de la vallée de l'Amazone. Vellosia, 2:41-46.

Bocquentin, J.-C. and Souza Filho, J.P.d. 1990. O crogodiliano Sul-Americano Carandaisuchus como sinonímia de Mourasuchus (Nettosuchidae). Revista Brasileira de Geociências, 20:230-233.

Bocquentin Villanueva, J. 1984. Un nuevo Nettosuchidae (Crocodylia, Eusuchia) proveniente da la Formación Urumaco (Mioceno Superior), Venezuela. Ameghiniana, 21:3-8.

Bona, P., Degrange, F.J., and Fernández, M.S. 2013a. Skull anatomy of the bizarre crocodylian Mourasuchus nativus (Alligatoridae, Caimaninae). The Anatomical Record, 296:227-239.

Bona, P. and Desojo, J.B. 2011. Osteology and cranial musculature of Caiman latirostris (Crocodylia: Alligatoridae). Journal of Morphology, 272:780-795

Bona, P., Riff, D., and Brandoni de Gasparini, Z. 2013b. Late Miocene crocodylians from northeast Argentina: new approaches about the austral components of the Neogene South American crocodylian fauna. Earth and Environmental Science Transactions of the Royal Society of Edinburgh, 103:551-570.

Bona, P., Riff, D., and Gasparini, Z. 2013c. Los Alligatoridae del Mioceno tardío de Argentina: el registro más austral de cocodrilos neógenos en América del Sur, p. 84-96. In Brandoni, D., and Noriega, J.I. (eds), El 
Neógeno de la Mesopotamia argentina. Asociación Paleontológica Argentina, Publicación Especial 14

Brochu, C.A. 1999. Phylogeny, systematics, and historical biogeography of Alligatoroidea. Society of Vertebrate Paleontology Memoir, 6:9-100.

Daudin, F.M. 1802. Histoire Naturelle Generale et Particuliere des Reptiles. Volume 2. Paris, F. Dufart.

Fortier, D.C., De Souza-Filho, J.P., Guilherme, E., Maciente, A.A.R., and Schultz, C.L. 2014. A new specimen of Caiman brevirostris (Crocodylia, Alligatoridae) from the late Miocene of Brazil. Journal of Vertebrate Paleontology, 34:820-834.

Foth, C., Bona, P., and Desojo, J.B. 2015. Intraspecific variation in the skull morphology of the black caiman Melanosuchus niger (Alligatoridae, Caimaninae). Acta Zoologica (Stockholm). 96(1):1-13.

Gasparini, Z.B. 1985. Un nuevo cocodrilo (Eusuchia) Cenozoico de América del Sur. Coletânea de Trabalhos Paleontológicos do IIX Congresso Brasileiro de Paleontologia, MME-DNPM, 27:51-53.

Gmelin, J.F. 1789. Caroli a Linné, Systema Naturae per regna tria naturae, secundum classes, ordines, genera, species, cum characteribus, differentiis, synonymis, locis. Editio Decima Tertia, Aucta, Reformata. Tomus I. Pars III. Lipsiae [Leipzig]: Beer, G.E. (ed.) 13, 1(3):1033-1516.

Gray, J.E. 1844. Catalogue of Tortoises, Crocodilians and Amphisbaenians in the Collection of the British Museum. British Museum (Natural History), London.

Gray, J.E. 1862. A synopsis of the species of alligators. Annals and Magazine of Natural History, Series 3, 10:327-331.

Hastings, A.K., Bloch, J.I., Jaramillo, C.A., Rincon, A.F., and MacFadden, B.J. 2013. Systematics and biogeography of crocodylians from the Miocene of Panama. Journal of Vertebrate Paleontology, 33:239263.

lordansky, N.N. 1973. The skull of the Crocodylia, p. 201-262. In Gans, C. and Parsons, T.S. (eds.), Biology of the Reptilia. Volume 4 - Morphology D. Academic Press, London.

Langston Jr., W. 1965. Fossil crocodilians from Colombia and the Cenozoic history of the Crocodilia in South America. University of California Publications of Geological Science, 52:1-169.

Langston Jr., W. 1966. Mourasuchus Price, Nettosuchus Langston, and the Family Nettosuchidae (Reptilia: Crocodilia). Copeia, 4:882-885.

Langston Jr., W. 2008. Notes on a partial skeleton of Mourasuchus (Crocodylia, Nettosuchidae) from the upper Miocene of Venezuela. Arquivos do Museu Nacional, Rio de Janeiro, 66:125-143.

Martin, B.G.H. and Bellairs, A.d.A. 1977. The narial excrescence and pterygoid bulla of the gharial, Gavialis gangeticus (Crocodilia). Journal of Zoology, 182:541-558.

Medina, C.J. 1976. Crocodilians from the Late Tertiary of northwestern Venezuela: Melanosuchus fisheri sp. nov. Breviora, No. 438:1-14.
Medem, F.J. 1958. The crocodilian genus Paleosuchus. Fieldiana Zoology, 39(21):227-247.

Mook, C. C. 1921. Notes on the postcranial skeleton in the Crocodilia. Bulletin of the American Museum of Natural History, 44:67-100.

Mook, C.C. 1941. A new fossil crocodilian from Colombia. Proceedings of the United States National Museum, 91(3122):55-58.

Moreno-Bernal, J.W., Head, J., and Jaramillo, C.A. 2016. Fossil crocodilians from the high Guajira Peninsula of Colombia: Neogene faunal change in northernmost South America. Journal of Vertebrate Paleontology, e1110586 [17 pages]. doi:10.1080/ 02724634.2016.1110586

Patterson, B., Lewis, A.D., Wood, R.C., Fisher, D.C., Repennig, R.W., and Stanford, M.F. 1972. Numeros de Campo, Venezuela (Junio - Julio 1972) MCZ [Field List of the 'Harvard Expedition' from the Museum of Comparative Zoology of Harvard University in June/July 1972], Caracas, Venezuela.

Price, L.I. 1964. Sobre o cranio de um grande crocodilideo extinto do Alto Rio Jurua, Estado do Acre. Anais da Academia Brasileira de Ciências, 36:59-66.

Quiroz, L.I. and Jaramillo, C.A. 2010. Stratigraphy and sedimentary environments of Miocene shallow to marginal marine deposits in the Urumaco Trough, Falcón Basin, western Venezuela, p. 153-172. In Sánchez-Villagra, M.R., Aguilera, O.A., and Carlini, A.A. (eds.), Urumaco and Venezuelan Palaeontology - The Fossil Record of the Northern Neotropics. Indiana University Press, Bloomington.

Riff, D. and Aguilera, O.A. 2008. The world's largest gharials Gryposuchus: description of G. croizati n. sp. (Crocodylia, Gavialidae) from the Upper Miocene Urumaco Formation, Venezuela. Paläontologische Zeitschrift, 82:178-195.

Riff, D., Romano, P.S.R., Oliveira, G.R., and Aguilera, O.A. 2010. Neogene crocodile and turtle fauna in northern South America, p. 259-280. In Hoorn, C. and Wesselingh, F.P. (eds.), Amazonia, Landscape and Species Evolution. 1st Edition. Blackwell Publishing, London.

Rovereto, C. 1912. Los cocodrilos fósiles en las capas del Paraná. Anales del Museo Nacional de Historia Natural de Buenos Aires, 15:339-368.

Salas-Gismondi, R. 2015. Evolution of Neotropical biodiversity: phylogeny, ecology, and biogeography of the Mesoeucrocodylia (Vertebrata: Crocodyliformes) from the Miocene of Peruvian Amazonia. Unpublished PhD thesis, Université Montpellier 2, Montpellier.

Salas-Gismondi, R., Antoine, P.-O., Baby, P., Brusset, S., Benammi, M., Espurt, N., de Franceschi, D., Pujos, F., Tejada, J., and Urbina, M. 2007. Middle Miocene crocodiles from the Fitzcarrald Arch, Amazonian Peru, p. 355-360. In Díaz-Martínez, E. and Rábano, I. (eds.), 4th European Meeting on the Palaeontology and Stratigraphy of Latin America Cuadernos del Museo Geominero, $n^{\circ}$ 8. Instituto Geológico y Minero 
de España, Madrid, 2007. Instituto Geológico y Minero de España, Madrid.

Salas-Gismondi, R., Flynn, J.J., Baby, P., Tejada-Lara, J.V., Wesselingh, F.P., and Antoine, P.-O. 2015. A Miocene hyperdiverse crocodylian community reveals peculiar trophic dynamics in proto-Amazonian mega-wetlands. Proceedings of the Royal Society $B, 282:$ 20142490. doi:10.1098/rspb.2014.2490

Sánchez-Villagra, M.R., and Aguilera, O.A. 2006. Neogene vertebrates from Urumaco, Falcón State, Venezuela: diversity and significance. Journal of Systematic Palaeontology, 4:213-220.

Scheyer, T.M., Aguilera, O.A., Delfino, M., Fortier, D.C., Carlini, A.A., Sánchez, R., Carrillo-Briceño, J.D., Quiroz, L., and Sánchez-Villagra, M.R. 2013. Crocodylian diversity peak and extinction in the late Cenozoic of the northern Neotropics. Nature Communications, 4:1907. doi:10.1038/ncomms2940

Scheyer, T.M. and Moreno-Bernal, J.W. 2010. Fossil crocodylians from Venezuela in the context of South American faunas, p. 192-213. In Sánchez-Villagra,
M.R., Aguilera, O.A., and Carlini, A.A. (eds.), Urumaco and Venezuelan Palaeontology - The Fossil Record of the Northern Neotropics. Indiana University Press, Bloomington.

Souza Filho, J.P.d. 1987. Caiman brevirostris sp., nov., um novo Alligatoridae da Formação Solimões (Pleistoceno) do Estado do Acre, Brasil. In: Anais X Congresso Brasileiro de Paleontologia, Rio de Janeiro, 19-25. July 1987:173-180.

Spix, J.B.d. 1825. Animalia nova sive species novae Lacertarum, quas in itinere per Brasiliam annis MDCCCXVII - MDCCCXX jussu et auspiciis Maximiliani Josephi I. Bavariae Regis suscepto collegit et descripsit, Leipzig.

Tineo, D.E., Bona, P., Martín Pérez, L., Dardo Vergani, G., González, G., Poiré, D.G., Gasparini, Z., and Legarreta, P. 2015. Palaeoenvironmental implications of the giant crocodylian Mourasuchus (Alligatoridae, Caimaninae) in the Yecua Formation (late Miocene) of Bolivia. Alcheringa, 39:224-235. 


\section{APPENDIX}

List of specimens studied.

\begin{tabular}{|c|c|c|}
\hline Accession number & Material & Locality/Age \\
\hline AMU-CURS-006 & Purussaurus isolated tooth & $\begin{array}{l}\text { North of Urumaco Town, Urumaco Formation, } \\
\text { Venezuela }\end{array}$ \\
\hline AMU-CURS-022 & Purussaurus isolated tooth & $\begin{array}{l}\text { North of El Picache, Urumaco Formation, } \\
\text { Venezuela }\end{array}$ \\
\hline AMU-CURS-033 & Purussaurus mirandai isolated teeth & Urumaco Formation, Venezuela \\
\hline AMU-CURS-049 & $\begin{array}{l}\text { C. wannlangstoni (sensu Salas-G. et al., 2015; was } \\
\text { labelled "Caiman lutescens") }\end{array}$ & Corralito, Urumaco Formation, Venezuela \\
\hline AMU-CURS-057 & $\begin{array}{l}\text { Purussaurus cf. mirandai (previously referred } \\
\text { specimen of } P \text {. mirandai by Aguilera et al. 2006) }\end{array}$ & Tío Gregorio, Urumaco Formation, Venezuela \\
\hline AMU-CURS-067 & Globidentosuchus brachyrostris additional specimen & Playa Larga, Urumaco Formation, Venezuela \\
\hline AMU-CURS-073 & Mourasuchus sp. & Tío Gregorio, Urumaco Formation, Venezuela \\
\hline AMU-CURS-083 & Globidentosuchus cf. G. brachyrostris & $\begin{array}{l}\text { Coquina Quebrada Bejucal, Urumaco Formation, } \\
\text { Venezuela }\end{array}$ \\
\hline AMU-CURS-084 & Globidentosuchus cf. G. brachyrostris & $\begin{array}{l}\text { Coquina Quebrada Bejucal, Urumaco Formation, } \\
\text { Venezuela }\end{array}$ \\
\hline AMU-CURS-090 & Caimaninae indet. (was Caiman) & $\begin{array}{l}\text { North of Mamon, Corralito, Urumaco Formation, } \\
\text { Venezuela }\end{array}$ \\
\hline AMU-CURS-100 & Caimaninae indet. & Norte El Picache, Urumaco Formation, Venezuela \\
\hline AMU-CURS-101 & Purussaurus isolated tooth & $\begin{array}{l}\text { North of El Picache, Urumaco Formation, } \\
\text { Venezuela }\end{array}$ \\
\hline $\begin{array}{l}\text { AMU-CURS-105/ } \\
106\end{array}$ & Caimaninae indet. (was Caiman brevirostris) & $\begin{array}{l}\text { West of Quebrada Tío Gregorio, Urumaco } \\
\text { Formation, Venezuela }\end{array}$ \\
\hline AMU-CURS-113 & $\begin{array}{l}\text { Caimaninae indet. (was Caiman brevirostris in Riff et } \\
\text { al. } 2010 \text { = Caiman sp. in Scheyer et al., } 2013 \text { from Loc. } \\
\text { Puente Rio Urumaco/Playa Larga) }\end{array}$ & $\begin{array}{l}\text { just NE of 'Northwest San Rafael'; Cerro Amarillo, } \\
\text { Urumaco Formation, Venezuela }\end{array}$ \\
\hline AMU-CURS-135 & Purussaurus mirandai paratype material & El Hatillo, Urumaco Formation, Venezuela \\
\hline AMU-CURS-162 & Purussaurus additional unprepared specimen & $\begin{array}{l}1.5 \mathrm{~km} \text { north of El Hatillo, Urumaco Formation, } \\
\text { Venezuela }\end{array}$ \\
\hline AMU-CURS-212 & $\begin{array}{l}\text { Mourasuchus arendsi (previously identified as } M \text {. } \\
\text { nativus) }\end{array}$ & $\begin{array}{l}\text { West of El Mamon, Urumaco Formation, } \\
\text { Venezuela }\end{array}$ \\
\hline AMU-CURS-217 & $\begin{array}{l}\text { Caimaninae indet. (previously identified as } \\
\text { Melanosuchus fisheri) }\end{array}$ & $\begin{array}{l}\text { Puente Rio Urumaco/Playa Larga, Urumaco } \\
\text { Formation, Venezuela }\end{array}$ \\
\hline AMU-CURS-218 & $\begin{array}{l}\text { Mourasuchus arendsi (previously identified as } M \text {. } \\
\text { nativus) }\end{array}$ & $\begin{array}{l}\text { Puente Rio Urumaco/Playa Larga, Urumaco } \\
\text { Formation, Venezuela }\end{array}$ \\
\hline AMU-CURS-222 & Globidentosuchus brachyrostris holotype & El Picache, Urumaco Formation, Venezuela \\
\hline AMU-CURS-223 & Globidentosuchus brachyrostris additional specimen & El Picache, Urumaco Formation, Venezuela \\
\hline AMU-CURS-224 & Globidentosuchus brachyrostris additional specimen & El Picache, Urumaco Formation, Venezuela \\
\hline AMU-CURS-234 & Caimaninae aff. Melanosuchus fisheri Medina, 1976 & El Hatillo, Urumaco Formation, Venezuela \\
\hline AMU-CURS -301 & Globidentosuchus brachyrostris additional specimen & $\begin{array}{l}\text { Domo de Agua Blanca, Urumaco Formation, } \\
\text { Venezuela }\end{array}$ \\
\hline AMU-CURS -383 & Globidentosuchus brachyrostris additional specimen & $\begin{array}{l}\text { Northwest San Rafael, Urumaco Formation, } \\
\text { Venezuela }\end{array}$ \\
\hline AMU-CURS-384 & Purussaurus sp. & $\begin{array}{l}\text { Northwest San Rafael, Urumaco Formation, } \\
\text { Venezuela }\end{array}$ \\
\hline AMU-CURS-394 & Purussaurus sp. & $\begin{array}{l}\text { Northwest San Rafael, Urumaco Formation, } \\
\text { Venezuela }\end{array}$ \\
\hline AMU-CURS-395 & Mourasuchus sp. & $\begin{array}{l}\text { Northwest San Rafael, Urumaco Formation, } \\
\text { Venezuela }\end{array}$ \\
\hline
\end{tabular}




\begin{tabular}{|c|c|c|}
\hline Accession number & Material & Locality/Age \\
\hline AMU-CURS-396 & Mourasuchus sp. & $\begin{array}{l}\text { Northwest San Rafael, Urumaco Formation, } \\
\text { Venezuela }\end{array}$ \\
\hline AMU-CURS-429 & $\begin{array}{l}\text { Caimaninae indet. (previously identified as Caiman } \\
\text { brevirostris) }\end{array}$ & El Mamón, Urumaco Formation, Venezuela \\
\hline AMU-CURS-430 & Mourasuchus sp. & $\begin{array}{l}\text { Loc Norte Las Huertas, SW of El Mamón, } \\
\text { Urumaco Formation, Venezuela }\end{array}$ \\
\hline AMU-CURS-442 & Purussaurus sp., additional unprepared specimen & Urumaco Formation, Venezuela \\
\hline AMU-CURS -450 & Globidentosuchus brachyrostris additional specimen & $\begin{array}{l}\text { Domo de Agua Blanca, Urumaco Formation, } \\
\text { Venezuela }\end{array}$ \\
\hline AMU-CURS-451 & Caimaninae indet. & Corralito Sur, Urumaco Formation, Venezuela \\
\hline AMU-CURS-528 & Purussaurus cf. P. mirandai & $\begin{array}{l}\text { Northwest San Rafael, Urumaco Formation, } \\
\text { Venezuela }\end{array}$ \\
\hline AMU-CURS-530 & Mourasuchus sp. & $\begin{array}{l}\text { Northwest San Rafael, Urumaco Formation, } \\
\text { Venezuela }\end{array}$ \\
\hline AMU-CURS-537 & Mourasuchus sp. & $\begin{array}{l}\text { Northwest San Rafael, Urumaco Formation, } \\
\text { Venezuela }\end{array}$ \\
\hline AMU-CURS-541 & Purussaurus sp. & $\begin{array}{l}\text { North of El Picache, Urumaco Formation, } \\
\text { Venezuela }\end{array}$ \\
\hline AMU-CURS-601 & Caimaninae indet. & $\begin{array}{l}\text { North of El Picache, Urumaco Formation, } \\
\text { Venezuela }\end{array}$ \\
\hline AMU-CURS-602 & Purussaurus cf. P. mirandai & $\begin{array}{l}\text { North of El Picache, Urumaco Formation, } \\
\text { Venezuela }\end{array}$ \\
\hline AMU-CURS-606 & Purussaurus sp. & $\begin{array}{l}\text { North of El Picache, Urumaco Formation, } \\
\text { Venezuela }\end{array}$ \\
\hline AMU-CURS-671 & Purussaurus sp. & $\begin{array}{l}\text { Corralito east of Rio Urumaco, Urumaco } \\
\text { Formation, Venezuela }\end{array}$ \\
\hline AMU-CURS-685 & Purussaurus cf. P. mirandai & Urumaco Formation, Venezuela \\
\hline AMU-CURS-695 & Mourasuchus sp. & Tío Gregorio, Urumaco Formation, Venezuela \\
\hline AMU-CURS-748 & Mourasuchus sp. & El Hatillo, Urumaco Formation, Venezuela \\
\hline AMU_CURS-768 & Mourasuchus arendsi large posterior skull part & $\begin{array}{l}\text { El Vijiadero, ca. } 6 \mathrm{~km} \text { south west of Urumaco } \\
\text { town, Lower Member, Urumaco Formation, } \\
\text { Venezuela }\end{array}$ \\
\hline MCNC-243 & Melanosuchus fisheri holotype skull & Corralito, Urumaco Formation, Venezuela \\
\hline MCNC-1829 & Caiman brevirostris & El Picache, Urumaco Formation, Venezuela \\
\hline $\begin{array}{l}\text { MCNC-URU-76- } \\
72 \mathrm{~V}\end{array}$ & Purussaurus mirandai referred specimen & $\begin{array}{l}0.5 \mathrm{~km} \mathrm{~N} \text { of Quebrada Picache / } 50 \mathrm{~m} \text { E of } \\
\text { Chiguaje Fault (sensu Patterson et al., 1972), } \\
\text { Urumaco Formation, Venezuela }\end{array}$ \\
\hline $\begin{array}{l}\text { MCNC-URU-90- } \\
72 \mathrm{~V}\end{array}$ & Purussaurus sp. & $\begin{array}{l}0.5 \mathrm{~km} \mathrm{~N} \text { of Quebrada Picache / } 50 \mathrm{~m} \mathrm{E} \mathrm{of} \\
\text { Chiguaje Fault (sensu Patterson et al., 1972), } \\
\text { Urumaco Formation, Venezuela }\end{array}$ \\
\hline $\begin{array}{l}\text { MCNC-URU-110- } \\
72 \mathrm{~V}\end{array}$ & $\begin{array}{l}\text { lower jaw and skull of Mourasuchus sp. (heavily } \\
\text { plastered/reconstructed specimen) }\end{array}$ & $\begin{array}{l}3.5 \mathrm{~km} \mathrm{~N} \text { and } 3 ? \mathrm{~W} \text { of El Picache on up side of } \\
\text { Chiguaje Fault (sensu Patterson et al., 1972), } \\
\text { Urumaco Formation, Venezuela }\end{array}$ \\
\hline $\begin{array}{l}\text { MCNC-URU-111- } \\
72 \mathrm{~V}\end{array}$ & Purussaurus sp. & $\begin{array}{l}3.5 \mathrm{~km} \mathrm{~N} \text { and } 3 \text { ? W of El Picache on up side of } \\
\text { Chiguaje Fault (sensu Patterson et al., 1972), } \\
\text { Urumaco Formation, Venezuela }\end{array}$ \\
\hline $\begin{array}{l}\text { MCNC-URU-115- } \\
72 \mathrm{~V}\end{array}$ & Purussaurus mirandai paratype material & $\begin{array}{l}\text { close to URU-76-72V, in bed of Quebrada Picache } \\
\text { (sensu Patterson et al., 1972; 'El Picache' in } \\
\text { Aguilera et al., 2006), Urumaco Formation, } \\
\text { Venezuela }\end{array}$ \\
\hline
\end{tabular}




\begin{tabular}{|c|c|c|}
\hline Accession number & Material & Locality/Age \\
\hline $\begin{array}{l}\text { MCNC-URU-157- } \\
72 \mathrm{~V}\end{array}$ & $\begin{array}{l}\text { (was wrongly indicated as paratype material of } \\
\text { Purussaurus mirandai, is postcranium of Purussaurus } \\
\text { sp. instead) }\end{array}$ & $\begin{array}{l}\text { Capa de Tortugas/ Corralito (s sensu Patterson et } \\
\text { al., 1972: locality data of 139-72V; 'Tio Gregorio' } \\
\text { in Aguilera et al. 2006), Urumaco Formation, } \\
\text { Venezuela }\end{array}$ \\
\hline $\begin{array}{l}\text { MCNC-URU-158- } \\
72 \mathrm{~V}\end{array}$ & $\begin{array}{l}\text { Purussaurus mirandai paratype material (was wrongly } \\
\text { accessioned before) }\end{array}$ & $\begin{array}{l}\text { Capa de Tortugas/ Corralito, Urumaco Formation, } \\
\text { Venezuela }\end{array}$ \\
\hline $\begin{array}{l}\text { MCNC-URU-2002- } \\
145\end{array}$ & C. latirostris (was identified as "Caiman lutescens") & $\begin{array}{l}\text { Capa de Tortugas/ Corralito, Urumaco Formation, } \\
\text { Venezuela }\end{array}$ \\
\hline $\begin{array}{l}\text { UNEFM-CIAAP- } \\
1297\end{array}$ & Mourasuchus arendsi holotype & $\begin{array}{l}\text { Corralito, Urumaco Formation, Venezuela } \\
\text { [‘Quebrada El Mamón. Río Urumaco / enero 1983‘ } \\
\text { according to UNEFM catalogue] }\end{array}$ \\
\hline $\begin{array}{l}\text { UNEFM-CIAAP- } \\
1333\end{array}$ & $\begin{array}{l}\text { right maxilla from type loc. of } M \text {. arendsi-specimen } \\
\text { missing }\end{array}$ & $\begin{array}{l}\text { Corralito, Urumaco Formation, Venezuela } \\
\text { [‘Quebrada EI Mamón. Río Urumaco / enero 1983‘ } \\
\text { according to UNEFM catalogue] }\end{array}$ \\
\hline $\begin{array}{l}\text { UNEFM-CIAAP- } \\
1367\end{array}$ & Purussaurus cranial and postcranial remains & $\begin{array}{l}\text { Right bank of Rio Urumaco, } 1.5 \text { (?) km N of El } \\
\text { Hatillo?, Urumaco Formation, Venezuela }\end{array}$ \\
\hline $\begin{array}{l}\text { UNEFM-CIAAP- } \\
1368\end{array}$ & large crocodylian teeth belonging to large gharial & $\begin{array}{l}\text { Right bank of Rio Urumaco, } 1.5 \text { (?) km N of El } \\
\text { Hatillo?, Urumaco Formation, Venezuela }\end{array}$ \\
\hline $\begin{array}{l}\text { UNEFM-CIAAP- } \\
1368 / 1372\end{array}$ & small Purussaurus skull fragment & $\begin{array}{l}\text { Right bank of Rio Urumaco, } 1.5 \text { (?) km N of El } \\
\text { Hatillo?, Urumaco Formation, Venezuela }\end{array}$ \\
\hline $\begin{array}{l}\text { UNEFM-CIAAP- } \\
1369\end{array}$ & Purussaurus mirandai holotype & $\begin{array}{l}\text { El Hatillo (sensu Aguilera et al., 2006), Urumaco } \\
\text { Formation, Venezuela [same locality as - } 1368 \\
\text { according to UNEFM catalogue] }\end{array}$ \\
\hline $\begin{array}{l}\text { UNEFM-CIAAP- } \\
1378\end{array}$ & Mourasuchus maxillary fragment & $\begin{array}{l}\text { Right bank of Rio Urumaco north of El Hatillo, } \\
\text { Urumaco Formation, Venezuela [additional info: } \\
\text { 'octubre de 1983. (P-2: Pozo Dos)' according to } \\
\text { UNEFM catalogue] }\end{array}$ \\
\hline $\begin{array}{l}\text { UNEFM-CIAAP- } \\
1432\end{array}$ & tooth of Purussaurus? & $\begin{array}{l}\text { ['P-2: Urumaco. Taparito. Este de la Quebrada } \\
\text { Picacho / enero 1984' according to UNEFM } \\
\text { catalogue] }\end{array}$ \\
\hline $\begin{array}{l}\text { UNEFM-CIAAP- } \\
1434\end{array}$ & Purussaurus sp. lower jaw fragment & Urumaco Formation, Venezuela \\
\hline $\begin{array}{l}\text { UNEFM-CIAAP- } \\
1445\end{array}$ & Purussaurus mirandai paratype & $\begin{array}{l}\text { El Hatillo (sensu Aguilera et al., 2006), Urumaco } \\
\text { Formation, Venezuela ['Urumaco. Taparito. Este } \\
\text { de la Quebrada Picacho / enero 1984'according to } \\
\text { UNEFM catalogue] }\end{array}$ \\
\hline $\begin{array}{l}\text { UNEFM-CIAAP- } \\
1447\end{array}$ & Mourasuchus maxillary fragments & $\begin{array}{l}\text { ['Urumaco. Taparito. Este de la Quebrada Picacho } \\
\text { / enero 1984'according to UNEFM catalogue] }\end{array}$ \\
\hline UNEFM -VF-03 & Mourasuchus sp. & Urumaco Formation, Venezuela \\
\hline UNEFM- VF-06 & Caimaninae indet. & Urumaco Formation, Venezuela \\
\hline UNEFM- VF-017 & Globidentosuchus cf. G. brachyrostris & El Hatillo, Urumaco Formation, Venezuela \\
\hline UNEFM- VF-019 & Caimaninae indet. & Urumaco Formation, Venezuela \\
\hline UNEFM- VF-022 & Caimaninae indet. & Urumaco Formation, Venezuela \\
\hline \multicolumn{3}{|c|}{ Additional specimens referred to in the text } \\
\hline $\begin{array}{l}\text { MCN-USB no } \\
\text { number }\end{array}$ & $\begin{array}{l}\text { Purussaurus cf. P. mirandai (Simon Bolivar Univ. } \\
\text { specimen at the Museo Paleontológico Urumaco) }\end{array}$ & Urumaco Formation, Venezuela \\
\hline DGM 526-R & Mourasuchus amazonensis holotype & Solimões Formation, Acre, Brazil \\
\hline MCZ 4336 & Melanosuchus fisheri, referred skull & Capa de Tortugas/ Corralito, Urumaco Formation \\
\hline MLP 73-IV-15-8 & Mourasuchus nativus holotype material & Ituzaingó Formation, Paraná area, Argentina \\
\hline
\end{tabular}




\begin{tabular}{lll}
\hline Accession number & \multicolumn{1}{c}{ Material } & \multicolumn{1}{c}{ Locality/Age } \\
\hline MLP 73-IV-15-9 & Mourasuchus nativus referred material & Ituzaingó Formation, Paraná area, Argentina \\
MUSM 2377 & Caiman wannlangstoni, holotype skull & Pebas Formation, lquitos area, Peru \\
MUSM 2378 & Mourasuchus atopus (?) & Pebas Formation, lquitos area, Peru \\
UFAC-196 & Caiman brevirostris holotype & Solimões Formation, Acre, Brazil \\
UFAC-1424 & was Mourasuchus nativus referred specimen, herein & Solimões Formation, Acre, Brazil \\
& considered as M. arendsi & \\
UCMP 39978 & $\begin{array}{l}\text { aff. Caiman wannlangstoni ?; "La Venta Caiman" as } \\
\text { "distinct entity of uncertain taxonomic affinities" }\end{array}$ & La Venta, Colombia \\
UCMP 38012 & Mourasuchus atopus type specimen & La Venta, Colombia \\
ZSM 76/1911 & Melanosuchus niger, extant specimen & extant species, no locality data \\
MACN PV 5416 & C. latirostris, partial right rostrum & Argentina \\
MACN PV 13551 & C. lutescens, holotype (skull table) & Argentina \\
\hline
\end{tabular}

